\title{
Substoichiometric molecular control and amplification of the initiation and nature of amyloid fibril formation: lessons from and for blood clotting. BioRXiv preprint.
}

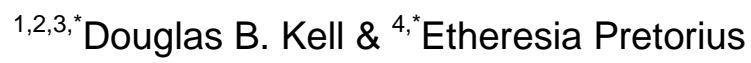

${ }^{1}$ School of Chemistry, ${ }^{2}$ The Manchester Institute of Biotechnology, and ${ }^{3}$ Centre for Synthetic Biology of Fine and Speciality Chemicals, The University of Manchester, 131, Princess St, MANCHESTER M1 7DN, Lancs, UK

${ }^{4}$ Department of Physiology, Faculty of Health Sciences, University of Pretoria, Arcadia 0007, South Africa.

*Corresponding authors: $\underline{\text { dbk@manchester.ac.uk and resia.pretorius@up.ac.za }}$

Keywords: amyloid - fibril - prion - blood clotting - LPS - amplification 
Substoichiometric molecular control and amplification of the initiation and nature of amyloid fibril formation: lessons from and for blood clotting. BioRXiv preprint.

Abstract.

Introduction: the thermodynamics of protein folding and prion proteins, and the existence of multiple macrostates

The terminal stages of normal blood clotting: fibrinogen, fibrin and thrombin

Methods for determining the clotting process

Optical methods based on fluorescence and birefringence

Congo Red. 15

Thioflavin S, Thioflavin T and derivatives

The conversion of fibrinogen to fibrin is normally not a transition from $\alpha$-helices to $\beta$-sheets except in special circumstances that include mutants........................................................ 20

Mechanical stretching can induce an $\alpha$-to- $\beta$ transition in a large variety of biopolymers ........... 20

Effects of flow on fibrin properties

When clotting goes wrong: hypercoagulability and hypofibrinolysis in chronic, inflammatory diseases

Clot retraction

Mutual effects of fibrin(ogen) on $\beta$-amyloid in Alzheimer's disease.

Small molecules that affect the nature of blood clotting and fibrin fibres in vitro ........................ 25

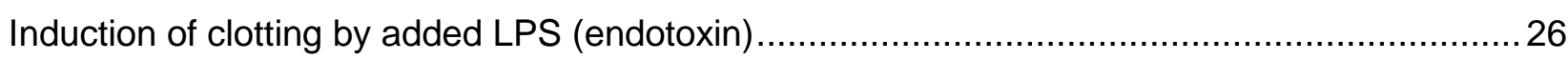

Anomalous blood clotting involves genuine amyloid formation ............................................ 26

The extent of amplification of protein transitions by LPS can be mimicked by liquid crystals ..... 27

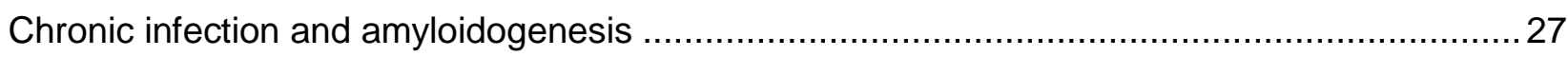

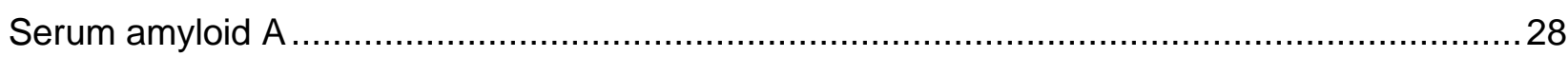

Possible treatments for coagulopathies in the light of their role in amyloidogenesis ................ 28

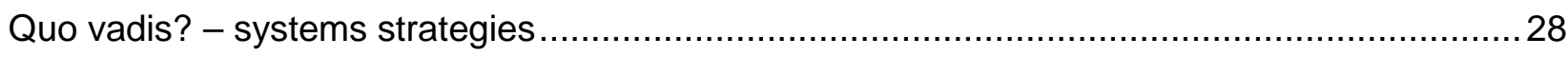

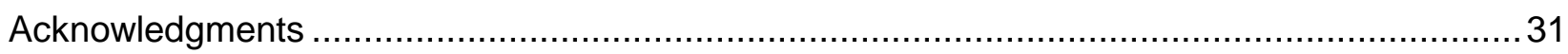

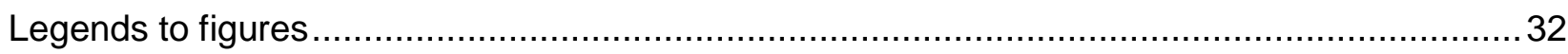

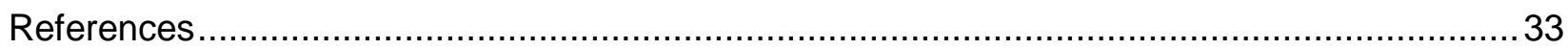


bioRxiv preprint doi: https://doi.org/101101/054734; this version posted May 21, 2016. The copyright holder for this preprint (which was

\section{Abstract}

The chief and largely terminal element of normal blood clotting is considered to involve the polymerisation of the mainly $\alpha$-helical fibrinogen to fibrin, with a binding mechanism involving 'knobs and holes' but with otherwise little change in protein secondary structure. We recognise, however, that extremely unusual mutations or mechanical stressing can cause fibrinogen to adopt a conformation containing extensive $\beta$-sheets. Similarly, prions can change morphology from a largely $\alpha$-helical to largely $\beta$-sheet conformation, and the latter catalyses both the transition and the self-organising polymerisation of the $\beta$-sheet structures. Many other proteins can also do this, where it is known as amyloidogenesis. When fibrin is formed in samples from patients harbouring different diseases it can have widely varying diameters and morphologies. We here develop the idea, and summarise the evidence, that in many cases the anomalous fibrin fibre formation seen in such diseases actually amounts to amyloidogenesis. In particular, fibrin can interact with the amyloid- $\beta$ (A $\beta$ ) protein that is misfolded in Alzheimer's disease. Seeing these unusual fibrin morphologies as true amyloids explains a great deal about fibrin(ogen) biology that was previously opaque, and provides novel strategies for treating such coagulopathies. The literature on blood clotting can usefully both inform and be informed by that on prions and on the many other widely recognised ( $\beta$-)amyloid proteins.

"Novel but physiologically important factors that affect fibrinolysis have seldom been discovered and characterized in recent years" [1] 
bioRxiv preprint doi: https://doi.org/101101/054734; this version posted May 21, 2016. The copyright holder for this preprint (which was

\section{Introduction: the thermodynamics of protein folding and prion proteins, and the}

\section{existence of multiple macrostates}

Starting with Anfinsen's famous protein re-folding experiments [2; 3], showing that an unfolded protein would refold reliably to its commonest (and original) state as found in the cell, it was widely assumed that the normal macrostate of a folded protein was that of its lowest free energy.

If one allows each amino acid to have $n$ distinct conformational substates, the total number $n^{\mathrm{m}}$ scales exponentially with the number $\mathrm{m}$ of amino acids [4], and until recently exhaustive calculations to determine whether the 'preferred' conformation was of lowest free energy were prohibitively expensive [5-8]; indeed, they still are save for small proteins, so this question of whether the 'normal' conformation is that of lowest free energy $( \pm k T)$ is certainly not settled in general terms, and (as we shall see in many cases) forms of lower free energy than the 'normal' one are in fact both common and of high biological significance.

In particular, as is again well known [9-12], and starting with Virchow's observations in 1854 [13], a number of proteins of a given sequence can exist in at least two highly distinct conformations [14]. Typically the normal ('benign') form, as produced initially within the cell, will have a significant $\alpha$ helical content and a very low amount of $\beta$-sheet, but the abnormal ('rogue') form, especially when in the form of an insoluble amyloid, will have a massively increased amount of $\beta$-sheet [15-18] (but cf. [19]), whether parallel or antiparallel [20]. The canonical example is the prion protein $\operatorname{PrP}^{c}$, whose abnormal form is known as $\operatorname{PrP}^{\mathrm{Sc}}$, and whose $\operatorname{PrP}^{\mathrm{c}}$ structure is shown in Fig 1. As is also well known, the monomers of the abnormal form may catalyse their own formation from the normal form, and will typically go on to self-assemble to form oligomers, protofibrils and finally insoluble fibrils [12]. (A particular hallmark of $\operatorname{PrP}^{\mathrm{Sc}}$, and indeed a common basis for its assay, is its very great resistance to proteolysis relative to $\mathrm{PrP}^{\mathrm{c}}$, typically assessed using proteinase $\mathrm{K}$ [21-27].)

Figure 1: $\operatorname{PrP}^{\mathrm{C}}$ conformation of human prion protein (1HJM at $\left.\mathrm{PDB}\right)$. 


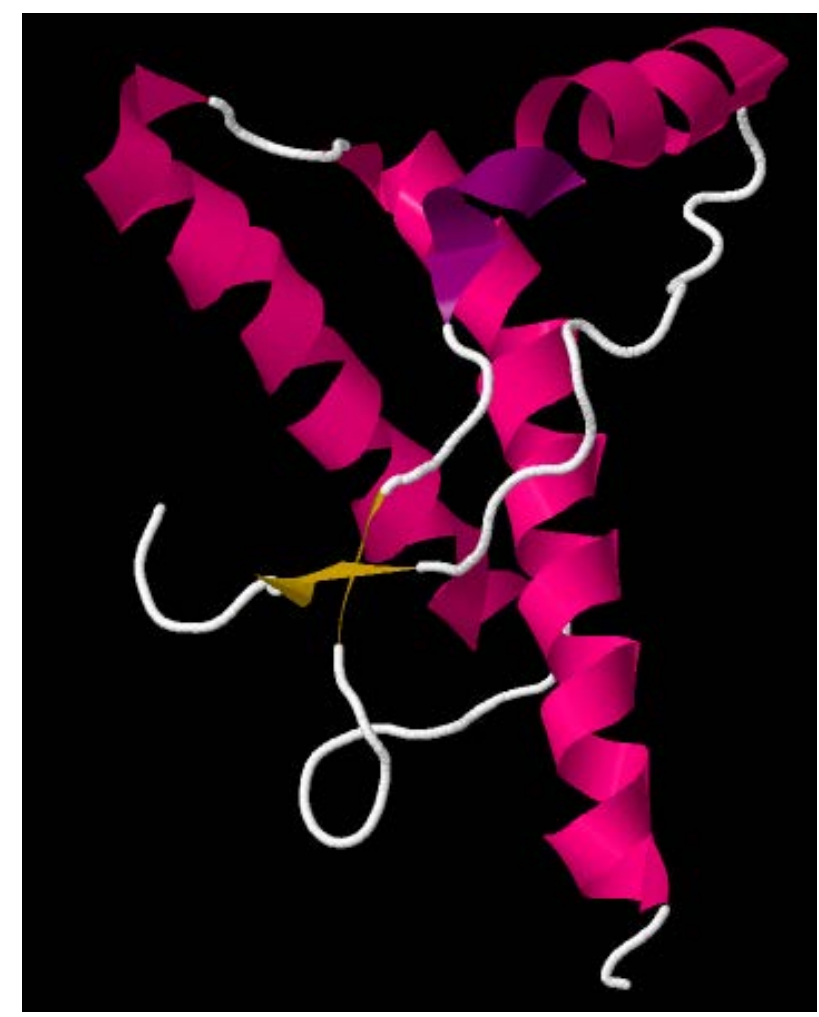

What this means [28] is that the 'normal' conformational macrostate of such proteins is not in fact that of the lowest free energy, and that its transition to the energetically more favourable 'rogue' state is thermodynamically favourable but under kinetic control, normally (in terms of transition state theory) with a very high energy barrier $\Delta \mathrm{G}^{\dagger}$ of maybe $36-38 \mathrm{kcal}^{\mathrm{mol}}{ }^{-1}$ [28] (Fig 2). Certainly, for a given and more tractable model sequence such as poly-L-alanine [29], a $\beta$-sheet is demonstrably more stable than is an $\alpha$-helix. However, the reversibility by pressure in some cases implies that the free energy change for oligomerisation is not particularly great [30]. The formal definition [31] of an amyloid fibril (protein) is as follows: "An amyloid fibril protein is a protein that is deposited as insoluble fibrils, mainly in the extracellular spaces of organs and tissues as a result of sequential changes in protein folding that result in a condition known as amyloidosis." 
bioRxiv preprint doi: https://doi.org/10.1101/054734; this version posted May 21, 2016. The copyright holder for this preprint (which was not certified by peer review) is the author/funder, who has granted bioRxiv a license to display the preprint in perpetuity. It is made available under aCC-BY 4.0 International license.

Figure 2: Kinetic isolation of $\mathrm{PrP}^{\mathrm{Sc}}$ from $\operatorname{PrP}^{\mathrm{C}}$ (based on [28]. Energy barrier

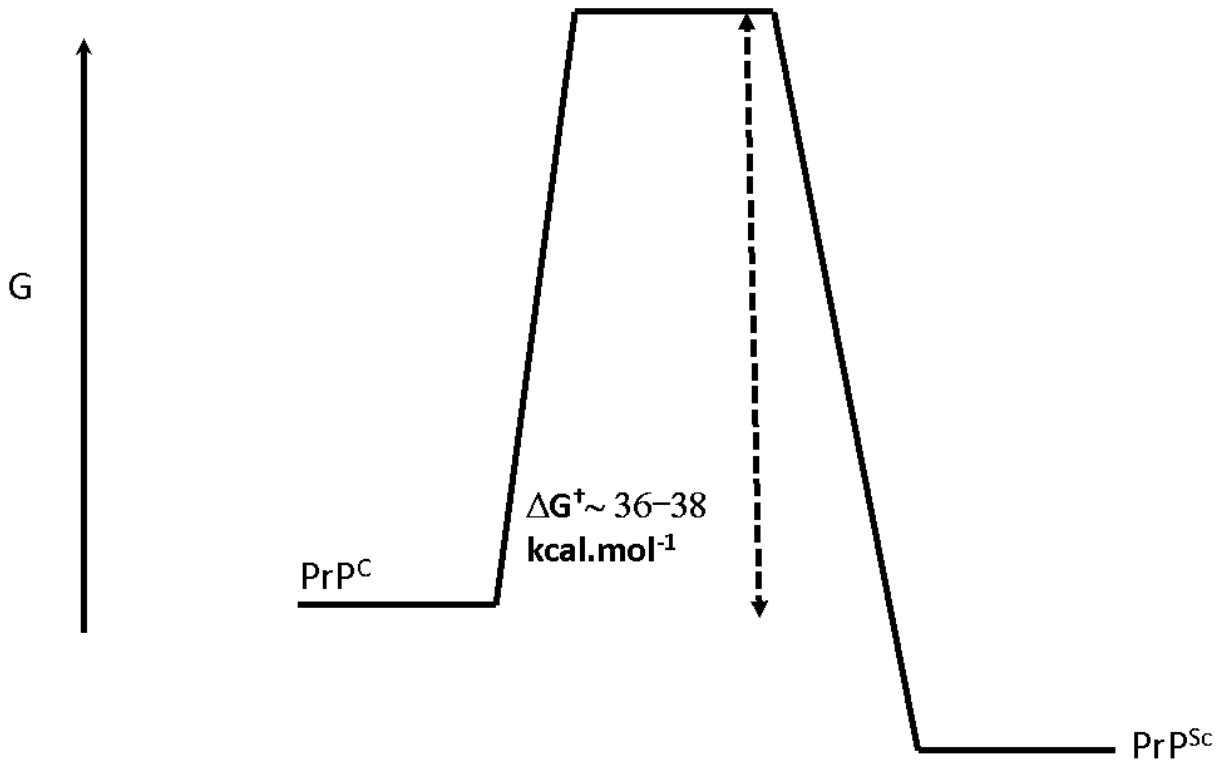

Multiple states or conformations of amyloid/prion 'strains' are sometimes referred to in this field as 'polymorphisms' [32], albeit they can have the same sequence [20]. Importantly, they can be selfpropagating [12; 14; 33-51]. Even amyloidogenic proteins as small as $A \beta_{1-40}$ can adopt as many as five stable conformations [52-55], that can vary in terms of protofilament number, arrangement and structure [52], as can a model 17mer [56-58]. Clearly self-seeding can propagate similar conformations [59].

An increasing number of human diseases is known to be associated with misfolded or amyloidtype proteins [60-66]. There are commonalities, in that amyloid proteins can cross-seed each other's polymerisation (e.g. [67-78]). By contrast, "expression of two $\operatorname{PrP}^{\mathrm{C}}$ moieties subtly different from each other antagonizes prion replication, and humans heterozygous for a common Prnp polymorphism at codon 129 are largely protected from CJD" [79]. Commonalities between prion protein misfolding and other protein misfolding diseases (AD, PD, ALS, etc [80]) that lead to amyloids are widely recognised; however, because the latter are not thought to be strictly infectious between individuals or across species, they have sometimes been referred to as prionoid diseases [81; 82]. This said, they are clearly transmissible if injected $[68 ; 70 ; 75 ; 77 ; 83-$ 
bioRxiv preprint doi: https://doi org/10.1101/054734; this version posted May 21, 2016. The copyright holder for this preprint (which was not certified by peer review) is the author/funder, who has granted bioRxiv a license to display the preprint in perpetuity. It is made available under aCC-BY 4.0 International license.

85] (and see above). For completeness, in biotechnology, one should add that amyloid formation can interfere with the activity of protein biologics (e.g. [86-89]), that bacterial inclusion bodies of recombinant proteins can also contain $\beta$-amyloid structures (e.g. [90-94]), and that at least some amyloid proteins are in fact beneficial to the host [95].

$\beta$-structures are inherently stable [96]. A characteristic "cross- $\beta$ " X-ray diffraction pattern is observed from amyloid fibres [20; 59]. A diffuse reflection at 4.7-4.8 $\AA$ spacing comes from extended protein chains running roughly perpendicular to the fibril and spaced 4.7-4.8 $\AA$ apart. $A$ more diffuse reflection at $10 \AA$ illustrates that the extended chains are organized into sheets spaced $\sim 10 \AA$ apart $[14 ; 97-100]$. However, it is possible to form $\beta$-structures in multiple ways, that underlie the different more-or-less stable conformations [14].

The first kind of conformational variation or polymorphism [14] is packing polymorphism. Here, an amyloid segment packs in two or more distinct ways, producing fibrils with different structures and distinctive properties, most simply as a registration shift in which the two sheets forming the steric zipper in the second polymorph shift their interdigitation from that in the zipper of the first polymorph, e.g. by a couple of amino acids. The second structural model for strains is termed segmental polymorphism; here, two or more different segments of an amyloid protein are capable of forming spines, and do so, leading to different fibril structures. Finally, in a third type of amyloid polymorphism, heterosteric zippers, the zipper is formed from the interdigitation of nonidentical $\beta$ sheets.

As well as by quite subtle changes in sequence [46; 101], the fibril morphology is determined by environmental factors, such as $\mathrm{pH}[56 ; 58]$, charge-neutralising polyanions [102; 103], temperature [56; 58], agitation [104], salts [105], lipids [106; 107], other co-solutes [108], small molecule additives [109] or even quite large protein sequences (and see below). To this end, a bacteriophage motif may be significantly anti-amyloidogenic and capable of remodelling formed amyloids [110]. At all events, the hallmark of these kinds of amyloidogenic behaviour [111] is the conversion of a soluble protein, typically a monomer, into an insoluble form that typically forms oligomers, protofilaments and then insoluble fibrils.

In summary, it is increasingly recognised that proteins can self-organise into fibrils that require only a conformational change (no sequence changes) and that these can vary as a function of both the sequence and environmental conditions. However, many of these processes occur on a rather sluggish timescale.

Another area in which a soluble precursor (fibrinogen) is converted into insoluble fibres (fibrin) occurs during the terminal stages of blood clotting. Perhaps surprisingly, this has not really been seen as a useful model for prion and amyloidogenic diseases, and certainly fibrin alone cannot 'seed' the growth of fibrin molecules, as each fibrinogen molecule added to the growing fibril 
requires that thrombin first releases two fibrinopeptides (see below). It is also a process that is necessarily and typically considerably quicker than classical amyloidogenesis. However, the main purposes of the present review are (i) to highlight the commonalities that do exist, and (ii) to illustrate in particular the very substantial changes in fibre morphology, including the recently discovered amyloid formation, that can be elicited by simple, and in many cases highly substoichiometric additions of small molecules. We believe that this will admit a substantial and useful cross-fertilisation of these fields. We highlight in particular the facts that (a) blood is much more easily available and amenable to study than are tissue materials, and (b) that at least some ligands, such as bacterial lipopolysaccharide (LPS), may be involved in both blood clotting and amyloidogenesis, and thus contribute to shared aetiologies.

\section{The terminal stages of normal blood clotting: fibrinogen, fibrin and thrombin}

The terminal stage of the coagulation cascade involves the conversion of fibrinogen to fibrin strands, and this involves a number of regulated steps (see Fig 3). Both the expansion and strength of the final clot is finely regulated and depends mostly on the conversion of fibrinogen to fibrin under the enzymatic action of thrombin, which (apart from a subsequent crosslinking induced by the transglutaminase factor XIII) is the final step in the cascade.

Figure 3: The coagulation cascade showing the final conversion of fibrinogen to fibrin. 


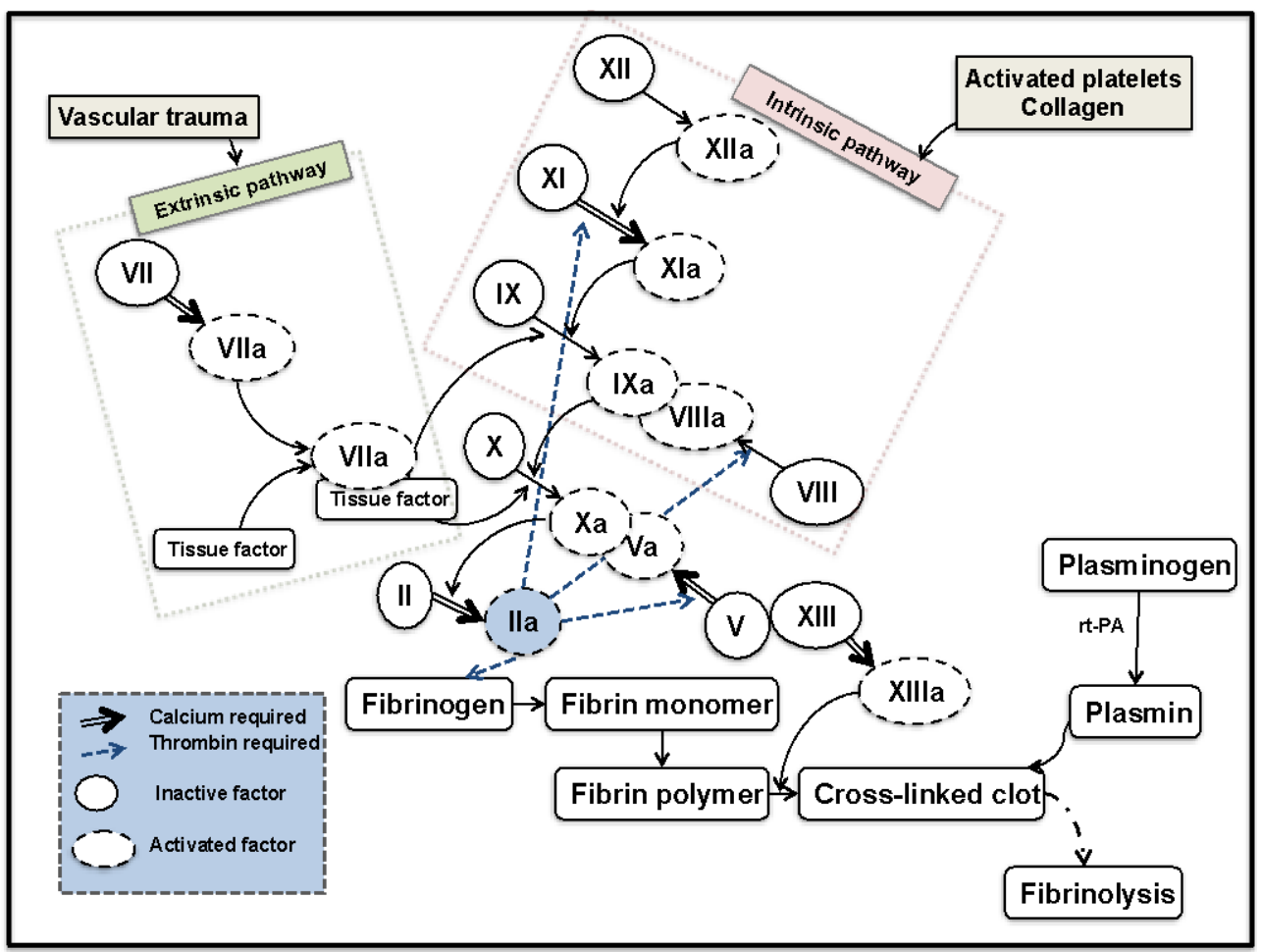

Fibrinogen circulates at high concentrations 2 to $4 \mathrm{mg} \cdot \mathrm{L}^{-1}$ [112] or at about $9 \mathrm{mM}$ in the plasma [113; 114], with a molecular mass of around $340 \mathrm{kDa}$. It has a centrosymmetric, trinodular, S-shaped structure that is $46 \mathrm{~nm}$ in length and $4.5 \mathrm{~nm}$ in diameter [115]. During coagulation, thrombin cleaves two $\mathrm{N}$-terminal peptides from the Aa- and B $\beta$-chains, promoting the formation of protofibrils and subsequently fibrin fibres [116; 117].

The fibrinogen protein consists of two sets each of three polypeptide chains $(A \alpha, B \beta, \gamma)_{2}$, [112] linked by $29 \mathrm{~S}-\mathrm{S}$ bonds [118] that has the basic structure shown in Fig 4.

Figure 4: Diagrammatic representation of fibrinogen packaging into the final product, the cross-linked fibrin mesh. 


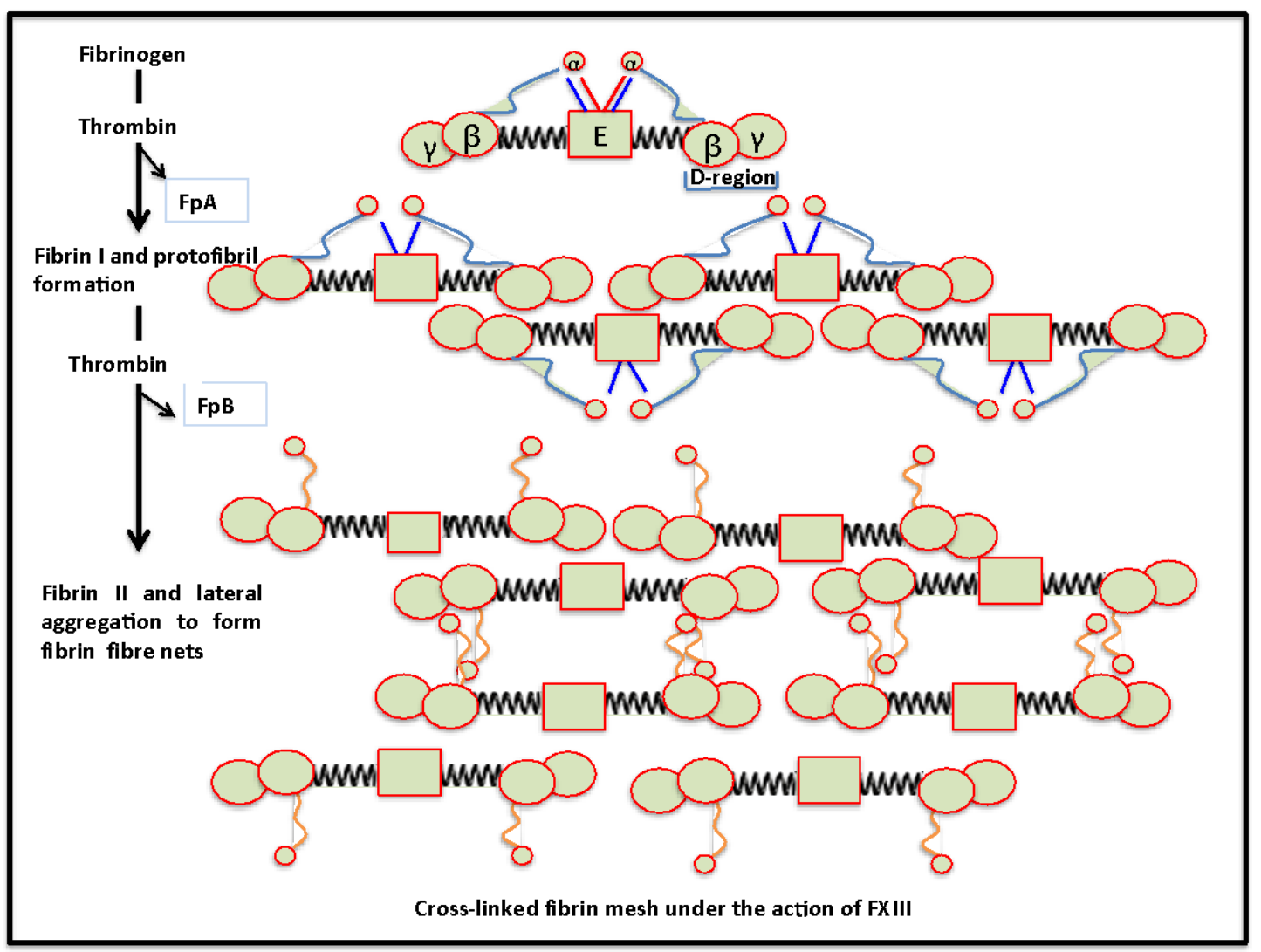

The main features are:

- A single central E-region; containing $6 \mathrm{~N}$-termini and fibrinopeptides $\mathrm{A}$ and $\mathrm{B}$

- Two D-regions flanking the E-region; each D-region contains a globular $\beta$ Cterminal domain ( $\beta 197-461$; called $\beta C$ ) and the globular $\mathrm{Y}$ C-terminal domain ( $\gamma 143-411$; called $\mathrm{yC}$ ), both of which consist of a $\beta$-sheet core flanked by a few small $\alpha$-helices [115].

- Two coiled coils consisting each of three $\alpha$-helices; these coils connect the E- and D-regions.

- There are also 29 disulphide bonds that acts as stabilizers; and 5 of these disulphide bonds are within the central E-nodule and forms a link between the two halves of the molecule.

- There are also 4 disulphide rings, consisting of 3 disulphide bonds that link the $\alpha$ - to the $\beta$-chain, the $\alpha$ - to the $\gamma$-chain, and the $\beta$-to the $\gamma$-chain. This forms a supporting unit that keeps the three $\alpha$-helices in the coiled coils together in each fibrinogen molecule; 1 ring at each end of the two coiled coils.

- Twelve intra-chain disulphide bonds, 3 in each of the 2 globular $\beta C$ domains of the D-regions, 2 in each of the two globular $\gamma C$ domain of the D-regions, and one in each of the two $\mathrm{aC}$ domains. 
Thrombin cleaves the fibrinogen, resulting in the fibrin monomers containing $A \alpha, B \beta$ and $Y$ polypeptides, which are then curved into the central E-region containing the 2 distal Dregions [119; 120]. Fibrin monomers are formed on the removal of 2 pairs of fibrinopeptides (fibrinopeptide $A$ and $B$ from the $N$-termini of the $A \alpha$ and $B \beta$ chains), converting it into a fibrin monomer that immediately polymerizes by self-assembly, to form a complex or a meshwork of fibrin fibres. Importantly, however, the fibrin monomer maintains major structural features of fibrinogen, including the coiled-coils [118]. When the 2 fibrinopeptides are removed from the $\mathrm{N}$-terminal region of the $\mathrm{A} \alpha$ - and $\mathrm{B} \beta$-chains, knoblike binding sites A and B, are exposed [115]. Finally, an insoluble fibrin gel complex is formed when the fibrin strands aggregate and form cross-links through the actions of thrombin-catalysed factor XIIIa [113; 121-125].

Plasma FXIII (fibrin stabilizing factor) is a plasma transglutaminase [124] and consists of two catalytic subunits (FXIII-A) and two non-catalytic subunits (FXIII-B) that are tightly connected in a non-covalent, heterotetramer $\left(F X I I I-A_{2} B_{2}\right)$. All FXIII-A $A_{2} B_{2}$ in the circulation are bound to fibrinogen [112]. FXIII- $\mathrm{A}_{2} \mathrm{~B}_{2}$ is activated by thrombin-catalyzed release of $\mathrm{N}$ terminal peptides from the FXIII-A subunits and calcium-mediated dissociation of the FXIIIB subunits, yielding activated FXIII-A 2 (or FXIIIa) [112].

Both plasma- and platelet-derived FXIIla catalyze the formation of $\varepsilon-\mathrm{N}$-( $\mathrm{\gamma}$-glutamyl)-lysyl crosslinks within fibrin [112] and this crosslinking stabilizes fibrin fibres and therefore clots [112]. XIIIa has profound effects on fibrin integrity and its seems that $\gamma$ - and $\alpha$-chain crosslinking make distinct contributions to clot function and structure [126; 127]. FXIIIa therefore plays in important role in the regulation of thrombus stability, regulation and cellmatrix interactions, including wound healing [127].

Recently, it was found that unperturbed (human) fibrin contains $30 \pm 3 \% \alpha$-helices, $37 \pm$ $4 \% \beta$-sheets, and $32 \pm 3 \%$ turns, loops, and random coils [118]. As discussed in detail later, under certain physiological (and also pathological) conditions, fibrin clots may undergo deformation, where molecular unfolding may occur $[118 ; 128 ; 129]$. Secondary structural alterations including the $\alpha$-helices and $\beta$-sheets transition, is a common mechanism of protein structural rearrangement. Increased force can result in the uncoiling of the $\alpha$-helices (or coiled coils) resulting in an increase of $\beta$-sheets. However, the simple binding of the fibrinopeptides to their corresponding holes on the D-regions does not result in any significant increase in $\beta$-sheets (See Fig 5 for a visual representation of when the formation 
of increased $\beta$-sheets and the uncoiling of the $\alpha$-helices does occur, e.g.undermechanical loading).

Figure 5: The $\alpha$-helices to $\beta$-sheets phase transition in fibrin formation under deformation of e.g. low (healthy coagulation) and high force (pathological coagulation) (adapted from [129]).

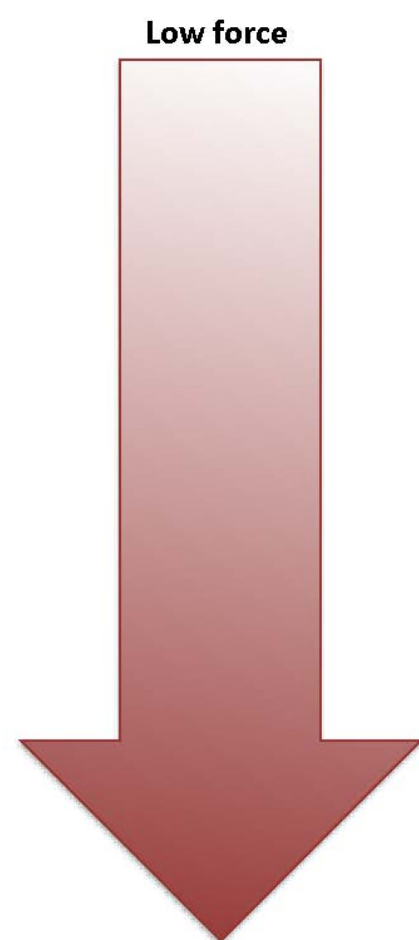

High force
Healthy coagulation
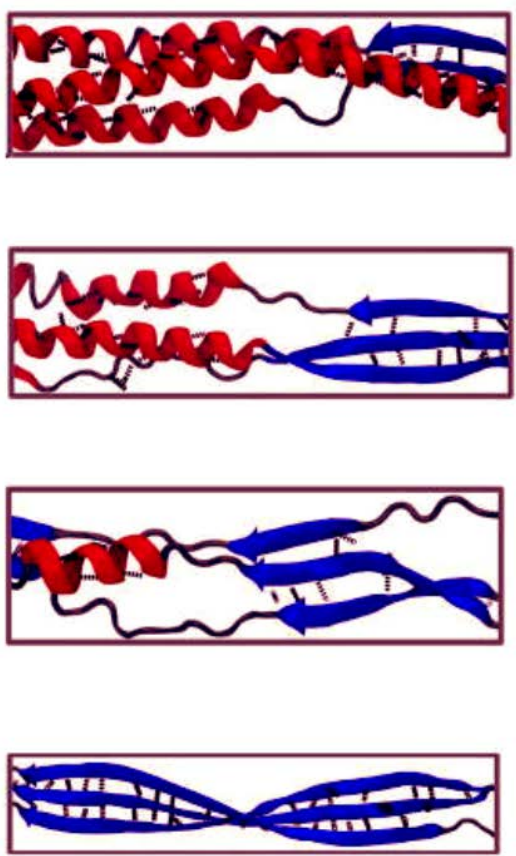

Pathological coagulation

These deformations affect the viscoelasticity at both the fibre and molecular levels and will translate into functional changes at the whole clot level. They also have implications in systemic changes of coagulation. Therefore, during the molecular extension of fibrin, $\alpha-$ helix to $\beta$-strand conversion occurs in coiled-coils and during both mechanical elongation and compression of fibrin clots, a rearrangement of the secondary clot structure occurs, comprising mainly the $\alpha$-helix-to- $\beta$-sheet transition [118]. The authors suggested that the $\alpha-\beta$ transition followed by formation of an intermolecular $\beta$-sheet structure and protein aggregation could be a common mechanism underlying the different types of fibrin deformation [118]. Here, we suggest that this may be the fundamental underlying reason for different fibrin fibre ultrastructures that we have previously reported on, where we found a changed macroscopically observable fibrin fibre structure during various systemic inflammatory conditions. 
bioRxiv preprint doi: https://doi org/10.1101/054734; this version posted May 21, 2016. The copyright holder for this preprint (which was not certified by peer review) is the author/funder, who has granted bioRxiv a license to display the preprint in perpetuity. It is made available under aCC-BY 4.0 International license.

Many excellent reviews exist on the mechanisms of clot formation and basic structure (e.g. [116; 130-136]), fibrinolysis [137-139], and the importance of clotting in vascular diseases [140-142]. Because of this, we can be relatively brief, and focus on the nub of our review, which is the argument that, like prions, fibrinogen can, under certain circumstances, form beta-sheet-rich amyloid fibrils.

\section{Methods for determining the clotting process}

Studying clot formation and degradation, using either plasma or whole blood, is important in the treatment of hyper- as well as hypocoagulability, and both optical and rheological/viscoelastometric methods have been developed (e.g. [143-147]); for a recent review, see [148]. Currently, visco-elastic technologies are mainly used as point-ofcare tests with immediately-available results; these include prothrombin time (PT), activated partial thromboplastin time (APTT), thromboelastography (TEG) and thromoboelastometry (ROTEM). Analyses that use plasma obtain results based on PT and APTT [149]; however, PT and APTT only test the coagulation protein component of the system, and results have to be interpreted carefully in the context of the clinical presentation and assay limitations [150]. Consequently, we rather favour the use of viscoelastic haemostatic methods such as TEG [149; 151 ; 152-154], ROTEM[152; 154-156] and the Sonoclot [157-159].

In the past our laboratory has focussed specifically on using the TEG [160-165]. See Table 1 for a comprehensive list of measurements that can be done using thromboelastography.

Table 1: TEG parameters typically generated for whole blood and platelet poor plasma [160; 161].

\begin{tabular}{|l|l|l|}
\hline \multicolumn{2}{|c|}{ THROMBOELSTIC PARAMETERS } \\
\hline R value: reaction time & Minutes & $\begin{array}{l}\text { Time of latency from start of test to initial fibrin } \\
\text { formation (amplitude of 2mm); i.e. initiation } \\
\text { time }\end{array}$ \\
\hline K: kinetics & Minutes & $\begin{array}{l}\text { Time taken to achieve a certain level of clot } \\
\text { strength (amplitude of 20mm); } \\
\text { implification }\end{array}$ \\
\hline $\begin{array}{l}\text { A (Alpha): Angle (slope between the } \\
\text { traces represented by R and K) ( }\end{array}$ & Angle in degrees & $\begin{array}{l}\text { The angle measures the speed at which fibrin } \\
\text { build up and cross linking takes place, hence } \\
\text { assesses the rate of clot formation; i.e. } \\
\text { thrombin burst }\end{array}$ \\
\hline MA: Maximal Amplitude & mm & $\begin{array}{l}\text { Maximum strength/stiffness of clot. Reflects } \\
\text { the ultimate strength of the fibrin clot, i.e. } \\
\text { overall stability of the clot }\end{array}$ \\
\hline $\begin{array}{l}\text { Maximum rate of thrombus generation } \\
\text { (MRTG) }\end{array}$ & $\begin{array}{l}\text { The maximum velocity of clot growth } \\
\text { observed or maximum rate of thrombus } \\
\text { generation using G, where G is the elastic } \\
\text { modulus strength of the thrombus in dynes } \\
\text { per cm }\end{array}$ \\
\hline $\begin{array}{l}\text { Time to maximum rate of thrombus } \\
\text { generation (TMRTG) }\end{array}$ & $\begin{array}{l}\text { The time interval observed before the } \\
\text { maximum speed of the clot growth }\end{array}$ \\
\hline Total thrombus generation (TTG) & $\begin{array}{l}\text { The clot strength: the amount of total } \\
\text { resistance (to movement of the cup and pin) } \\
\text { generated during clot formation. This is the } \\
\text { total area under the velocity curve during clot } \\
\text { growth, representing the amount of clot }\end{array}$ \\
\hline
\end{tabular}


bioRxiv preprint doi: https://doi.org/10.1101/054734- this version posted May 21, 2016. The copyright holder for this preprint (which was not certified by peer review) is the author/funder, who has granted bioRxiv a license to display the preprint in perpetuity. It is made available under aCC-BY 4.0 International license.

\begin{tabular}{|l|l|l|}
\hline & & strength generated during clot growth \\
\hline Lysis 30 (LY30) & $\%$ & Percentage lysis obtained 30 min after MA \\
\hline
\end{tabular}

Another important technique that we have combined with the TEG results, with great success, is scanning electron microscopy of fibrin fibre structure [148; 160-171]. These methods give a visual representation of clot structure, where the fibrin packaging can be studied at high resolution and magnification, and have illustrated the very great differneces that can be observed in plasma from diseased vs healthy controls. As mentioned in the previous paragraphs, PT, PTT, TEG, as well as ROTEM have been used successfully as point-of-care methods, while electron microscopy has been used mostly in the laboratory. However, the usefulness of combining the technologies in an integrated approach is clear $[161 ; 165 ; 172]$.

\section{Optical methods based on fluorescence and birefringence}

As with fluorescent proteins such as GFP, the ability to detect amyloid (and cross- $\beta$ motifs more generally) by optical means would improve their ease of study enormously. Fortunately, a number of appropriate dyes are known (Fig 6).

Figure 6: Examples of amyloid staining reagents. 
<smiles>Cc1ccc2c(c1)sc(-c1ccc(N(C)C)cc1)[n+]2C</smiles>

Congo Red [173-182] (CR) was one of the first dyes known to bind to amyloid [183]. Its name derives [184] from the marketing activities of the Berlin-based AGFA textile dyestuff company in 1885, following various geopolitical events of that time, but otherwise has no connection with central Africa. Bennhold [185] was the first to describe its binding to amyloid. This induces a characteristic shift in CR's maximal optical absorbance from $490 \mathrm{~nm}$ to $540 \mathrm{~nm}$, and rather variable [175-177; 186] birefringence and dichroism. As Howie and Brewer rather nicely put it [176], "Amyloid stained by Congo red has striking optical properties that have mostly been badly described and inadequately explained", although in general terms the birefringence clearly reflects the binding to the oriented $\beta$-sheets, with the orientation being increased by the practice of making smears. There is evidence for the particular involvement of histidine residues [178; 187]. Because the colours seen vary rather markedly with the relative orientations of polariser and analyser in the birefringence measurements $[175-177 ; 186], C R$ is seen as a stain that is less than perfectly reproducible, and it has largely been overtaken by fluorescent stains.

\section{Thioflavin S, Thioflavin T and derivatives}

The thioflavin stains (based on a thiazole nucleus) probably count most nearly as "God's gift to students of amyloid and amyloidogenesis". Free thioflavin T (ThT) fluoresces faintly with excitation 
and emission maxima of 350 and $440 \mathrm{~nm}$, respectively, whereas upon interaction with amyloid fibrils a substantially enhanced ThT fluorescence is observed, with excitation and emission maxima at about 440/450 and 480/490 nm, respectively [188-204]. Table 2 summarises the wavelengths used in a number of studies.

Table 2: Wavelengths that have commonly been used for excitation and emission when assessing Thioflavin T interaction with $\beta$-amyloids.

\begin{tabular}{|c|c|c|}
\hline Excitation (nm) & Emission (nm) & References \\
\hline 455 & 485 & [205] \\
\hline 440 & 490 & [206] \\
\hline 440 & 485 & [207] \\
\hline 435 & 480 & [208] \\
\hline 450 & $460-600$ & [209] \\
\hline 440 & $460-570$ & [210] \\
\hline 440 & 490 & [211] \\
\hline 450 & 482 & [212] \\
\hline $440 / 20$ & $485 / 20$ & [193] \\
\hline $440-450$ & $480-490$ & [195] \\
\hline 450 & 482 & [196] \\
\hline 445 & 485 & [213] \\
\hline 440 & 485 & [202] \\
\hline 450 & 480 & [214] \\
\hline 449 & 480 & [199] \\
\hline 440 & $<600$ & [203] \\
\hline
\end{tabular}


bioRxiv preprint doi: https://doi org/10.1101/054734; this version posted May 21 2016. The copyright holder for this preprint (which was not certified by peer review) is the author/funder, who has granted bioRxiv a license to display the preprint in perpetuity. It is made available under aCC-BY 4.0 International license.

As with $\mathrm{CR}$, the fluorescence enhancement is caused by binding to oriented $\beta$-rich fibrils. Fig 7 shows the conversion of typical amyloid-free fibrin fibres to highly-amyloid-rich ones as judged by their staining with ThT, added to plasma from a patient with thromboembolic stroke (Fig 7B) and compared with the same treatment of plasma from a matched, healthy control. The difference is rather striking.

Figure 7: Fibrin fibres from a healthy individual $(\mathbf{A})$ and an individual who had suffered a thromboembolic stroke (B), stained with ThT (5 $\mu \mathrm{M}$ final concentration) and viewed using a confocal microscope. Scale bar: $10 \mu \mathrm{m}$. 


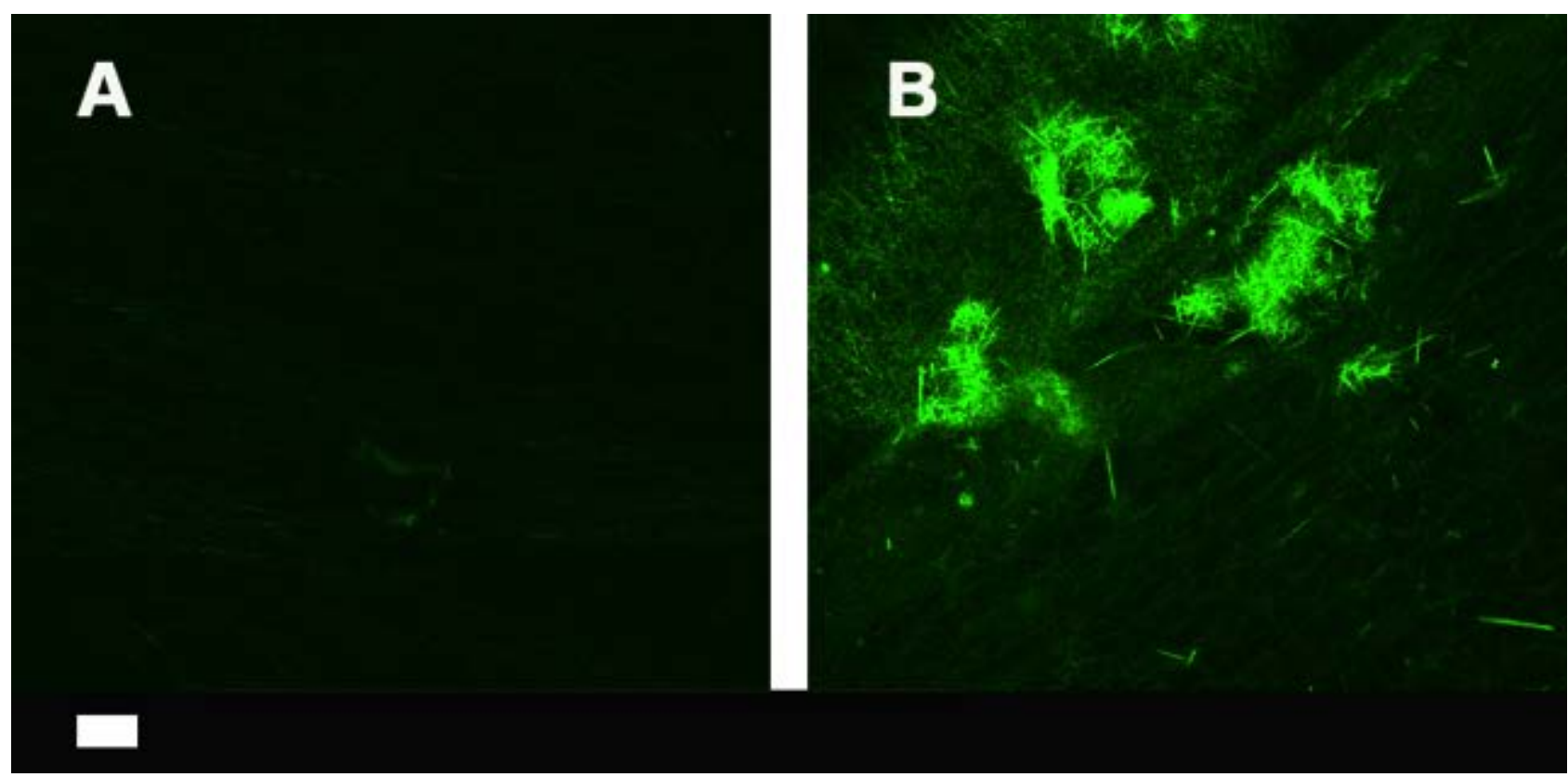

As a dibenzothiazole dye [215], Thioflavin S (ThS) is a somewhat extended version of ThT (Fig 6). We are not aware of any direct comparisons of THS and ThT, though ThS has been improved for tissue staining [216]. Consequently, it may seem sensible to use the smaller dye. Protein transporters are required to get xenobiotics into cells [217-220]. For tissue staining, even ThT does not penetrate the blood-brain barrier, and a neutral version known as Pittsburgh compound B (PIB) (Fig 6) has been developed that can [221-223]. (Based on its structure and the analyses presented elsewhere [224; 225], the three Recon 2(.2) metabolites [226-228] and marketed drugs to which it is most similar are given in Fig 8). However, while its ${ }^{11} \mathrm{C}$-derivative has been widely used in PET imaging of fibrils (e.g. [222; 223; 229-232]), PIB lacks the large optical absorbance shift and fluorescence enhancement characteristic of ThS and ThT [222].

Figure 8: The three endogenous metabolites and marketed drugs most closely related to PIB, as assessed using the MACCS encoding [233] and the Tanimoto distance. 
Recon2 metabolites

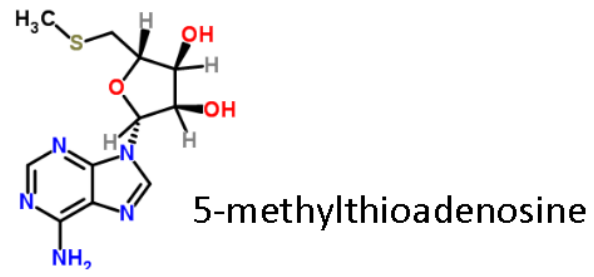<smiles>CC1=C(C)C(=O)c2c(c[nH]c2C)C1=O</smiles>

melanin<smiles>CNCCc1c[nH]c2ccc(O)cc12</smiles>

Riluzole

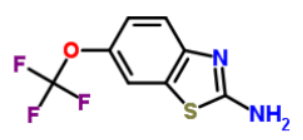

Tolnaftate

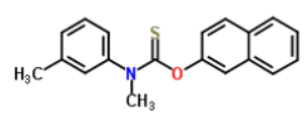

Methotrimeprazine

Other amyloid-selective dyes that have been used include X-34 (Excitation 400nm/Emission $455 \mathrm{~nm}$ ), which is in fact a fluorescent derivative of CR [234-236], chrysamine G [237; 238] (Fig 6) (which is excited at 386nm) and ANCA (excitation 380-430, emission 525-550). Since it is normally desirable to be able to excite nearer the red to decrease autofluorescence, and most of these latter are not commercially available, it is not obvious that these dyes bring great benefits over ThT.

In an interesting development, Stefansson and colleagues [239] noted that (i) the thiazole moiety is critical to binding [201], and (ii) that a number of modern, sensitive DNA-intercalating dyes also contain the thiazole nucleus. They showed [239] that these dyes too would bind to $\beta$-amyloid fibrils, albeit not normally (but cf. [240]) with quite with the same fluorescence enhancement as shown by ThT. However, they could be used in combination with ThT to increase the Stokes shift (via fluorescence resonance energy transfer) quite hugely into the red. Note though that the binding of these [241] and related dyes [242] to double-stranded DNA can be detected at the level of the single molecule, so such DNA must be absent. There is no doubt that continuing improvements in dye development will be of considerable value to the field. 
bioRxiv preprint doi: https://doi.org/101101/054734; this version posted May 21, 2016. The copyright holder for this preprint (which was

\section{The conversion of fibrinogen to fibrin is normally not a transition from $\alpha$-helices}

\section{to $\beta$-sheets except in special circumstances that include mutants}

A clear characteristic of the conversion of amyloidogenic proteins to genuine insoluble amyloids is the conversion of structures with (typically) predominantly $\alpha$-helices to structures with a (much) greater $\beta$-sheet content. The obvious question is to what extent is this similarly true in normal and abnormal clotting processes?

As seen in the section on normal blood clotting, the chief mechanism involves a 'knobs and stalks' interaction (that includes the ability to repair fibrils isoenergetically [243]), and that does not of itself require, nor does it seemingly provide, any major conformational changes in the secondary structure of the fibrinogen monomers [130; 244-247]. In a similar vein, normal blood clotting is not considered to be an amyloidogenic process, except in very rare cases of particular mutants of the fibrinogen a chain [248-254].

\section{Mechanical stretching can induce an $\alpha$-to- $\beta$ transition in a large variety of}

\section{biopolymers}

As judged by infrared spectroscopy of the various amide bands, standard human fibrin is about $30 \% \alpha$-helix, $40 \% \beta$-sheet and 30\% turns [255], similar to the numbers given (above) by Litvinov et al. [118]. This percentage changes with pressure and mechanical unfolding [118; 128; 129], but only at extremes of stretching (that apparently do not happen in normal clot formation), are the mechanical properties of fibrin considered to reflect an $\alpha$-to- $\beta$ transition [115; 256-258]. Specifically, at a certain extension there is what amounts to a phase transition. There were also some striking nonlinearities noted in the detailed studies of Münster and colleagues [259] and of Kim and colleagues [260].

It is of some interest that mechanical forces can also be used to effect an $\alpha$-to- $\beta$ transition in prions [261] and a variety of other elastomeric biopolymers [258; 262-264], not least keratin [256; 265267]. It is particularly noteworthy that after two- and three-fold longitudinal stretching the median fibre diameter and pore area in SEM images of fibrin decreased two- to three-fold [268], just as in a number of the disease states mentioned above, and that this conferred proteolytic resistance to the fibrin,

What the above examples tell us is that under normal circumstances human fibrin does not adopt a form that has a $\beta$-sheet content greater than $\sim 40 \%$, but that it can indeed do so under the appropriate circumstances.

\section{Effects of flow on fibrin properties}

The above studies involved mechanical stretching, but (given that blood does flow in the circulation) there has been some interest in the effects of flow (velocity) on fibrin structure. 
Increases in fibre thickness. Hints of $\beta$-sheet formation induced by flow can be seen in [269], while in a very striking study, Campbell et al. [270] saw a huge increase in the flow-induced diameter of fibrin fibres, from a mean of 79 to $226 \mathrm{~nm}$.

\section{When clotting goes wrong: hypercoagulability and hypofibrinolysis in chronic,}

\section{inflammatory diseases}

In inflammatory conditions, hypercoagulability, as well as hypofibrinolysis is a common phenomenon and both are seen as coagulopathies; see [148] for a table with a comprehensive list of inflammatory diseases with both known hypercoagulable and hypofibrinolytic characteristics. Our particular interest has been the study of clot structure using scanning electron microscopy, and we have noted that this method shows us precisely the diameter of individual fibrin fibres, as well as the general clot architecture (e.g. [168; 271-280]. We and others have shown that the diameter of 'typical' healthy fibrin fibres is 80 to $110 \mathrm{~nm}$ [148; 160; 281; 282], while during inflammation, clot diameter changes. It may be increased, as seen in Alzheimer's type dementia [160], or decreased as seen in stroke [281]. Up to now we have had no knowledge of the exact molecular conformational changes (e.g. the $\alpha$-helices and $\beta$-sheets) that happen during inflammation; we have just reported on the more macroscopically observable structural changes that are visible in the different conditions (See Fig 9). Now it has become clear that the exact changes that happen during inflammation in the $\alpha$-helix and $\beta$-sheet interaction might be of great importance to understand both hypercoagulability and hypofibrinolysis.

Figure 9: Representative micrographs of different inflammatory conditions. A) Healthy fibrin fibre structure; B) thromboembolic stroke; C) Alzheimer's type dementia; D) Type II diabetes. White arrows: fine netted areas; Red arrow: areas where fibrin fibres are thicker. Scale bar: 1 $\mu \mathrm{m}$. 

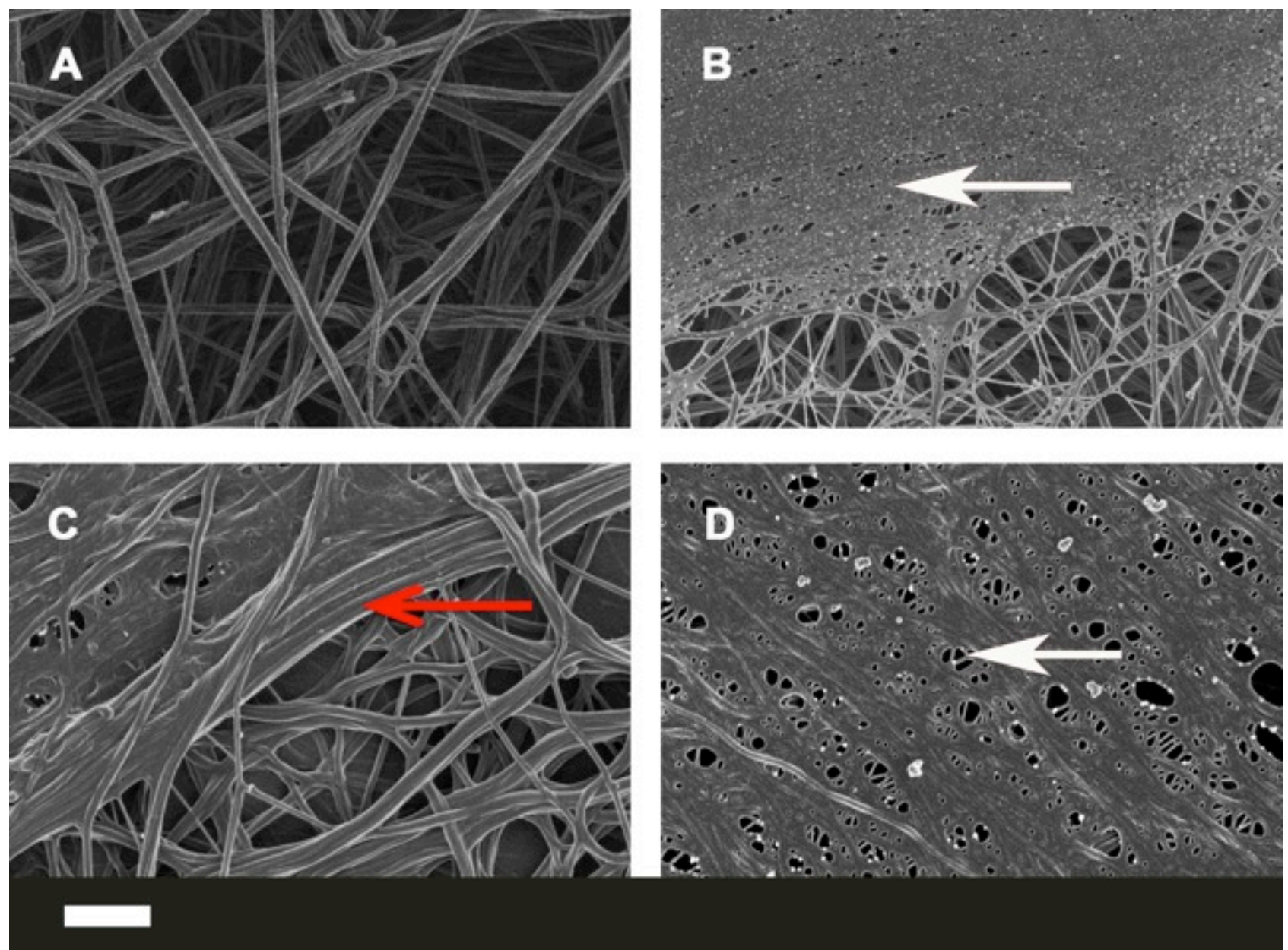

In vivo, as part of normal wound healing, the clot is removed via the fibrinolytic system and this process is mediated by the serine protease plasmin, which cleaves the fibrin molecule at specific sites $[283 ; 284]$ to form a variety of degradation products collectively referred to as $D$ dimer [285; 286]. (Whether D-dimer can adopt a $\beta$-sheet of amyloid form is apparently unknown, and its concentration varies but little during amyloidosis [287].) During fibrin polymerization, normally cryptic plasminogen and plasmin binding sites are exposed. These binding sites are situated on the $\mathrm{aC}$ regions that contain lysine-dependent tPA- and plasminogen-binding sites [283; 288]. During fibrinolysis, plasmin initially cleaves the $\mathrm{aC}$ regions, and then cleaves the three polypeptide chains connecting the E-domains and the D-domains [283; 289]. The exact process of fibrinolysis is controlled by various structural arrangements and physical properties of the clot itself. These properties include clot density, stiffness and fibrin fibre diameter [131; 290; 291]. Bucay and co-workers in 2015 found that if fibres are exposed to plasmin, thin fibres are easily cleaved, and that thicker fibres grew in length during fibrinolysis. Therefore the lytic susceptibility of a fibre is directly related to the intrinsic strain on the fibre resulting from the polymerization process [283]. Here we also suggest that the lysine-dependent tPA- and 
bioRxiv preprint doi: https://doi.org/10.1101/054734; this version posted May 21, 2016. The copyright holder for this preprint (which was

plasminogen-binding site accessibility on the fibrin fibres will be crucial for successful fibrinolysis and therefore the arrangement of the $\alpha$-helix and $\beta$-sheets will be of fundamental importance in this process. The difficulty or resistance of hydrolysis of abnormal fibrin clots can be directly compared to this "hypohydrolysis" (proteinase $\mathrm{K}$ resistance) characteristic of $\mathrm{PrP}^{\mathrm{Sc}}$, discussed in detail above.

As summarised by Campbell and colleagues [270], diameter per se can affect fibrinolysis rates: "Fibre diameter and network density play significant roles in clot dissolution [292]. Compared to thin fibres, thick fibres support faster plasmin generation rates. Plasmin lyses fibrin via laterally transecting individual fibres. Thin fibres lyse faster than thick fibres; however, coarse networks of thick fibres lyse faster than tight networks of thin fibres [293]." However, we suggest here that it may also be secondary structure that plays the major role.

One of the most damaging forms of hypercoagulation is known as disseminated intravascular coagulation [294-298]. It is essentially a runaway form of hypercoagulation, and it too may be induced by LPS (endotoxin) [294; 299-302]. There is significant evidence that it can itself lead to multiple organ failure and death [303]. It does not yet seem to be known, but seems probable, that the form of fibrin in DIC is indeed a $\beta$-amyloid.

Clot retraction. Clot retraction (contraction) is a physiological process initiated by platelets that results in compaction of the fibrin network and expulsion of the majority of serum from the clot together with the majority of unbound plasminogen, typically over a $24 \mathrm{~h}$ period in vivo [304]. It reflects in part the crosslinking of fibrin effected by Factor XIII [305-307]. According to Weisel [1], commenting on the important Varjú paper [268], so-called retracted clots are much more resistant to lysis [308-310], and retracted clots probably provide a useful model for events such as stroke. Clots are much stiffer in diseases such as multiple myeloma [311; 312]. It is not yet apparently known whether clot retraction is accompanied by $\beta$-sheet formation.

\section{Mutual effects of fibrin(ogen) on $\beta$-amyloid in Alzheimer's disease}

We rehearsed above how there was a limited (non-zero) cross-reactivity between heterologous amyloidogenic proteins, and an example of particular interest is given by the interaction between fibrin(ogen) and $\beta$-amyloid, as developed by Strickland and colleagues [313-320]. We rehearse their highly important arguments and findings in some detail.

As pointed out by Paul and colleagues [319], fibrinogen is present in the brains of AD patients [321], but the pathologic significance is or was not known. Using mutant mice, they showed the definite contribution of fibrin to the aberrant pathology [319]. As is well known, the extracellular plaques in the $A D$ brain are composed mainly of a 40-42 amino acid peptide, the $\beta$-amyloid or amyloid- $\beta(A \beta)$ peptide that is derived proteolytically from the $N$-terminus of the so-called amyloid- $\beta$ precursor protein (APP). There is little doubt (the 'amyloid hypothesis' [84; 322-326]) that A $\beta$ plays 
bioRxiv preprint doi: https://doi.org/10.1101/054734; this version posted May 21, 2016. The copyright holder for this preprint (which was not certified by peer review) is the author/funder, who has granted bioRxiv a license to display the preprint in perpetuity. It is made available under aCC-BY 4.0 International license.

some kind of significant role in $A D$, albeit that measures designed to remove it have not led to useful therapeutics [327-331]. The probable reason for this is simply that it is not the sole actor [332], and certainly its interactions with iron salts are central to disease development and loss of cognition (e.g. [148; 333-344]. 'Iron' interacts with fibrinogen too [168; 169; 171; 345], as does ferritin [346]. Here we rehearse and develop the additional idea that it is the interactions of $A \beta$ with fibrin(ogen), leading to amyloid fibril formation, that may provide a significant contribution to the neurodegeneration.

An important starting recognition [315] is that plasma fibrinogen levels are raised in AD [347-352], as is coagulability [148; 353]. The extent of fibrin deposition reflects the plasma fibrinogen level as it is modified by genetic or pharmacological means [315]. Fibrinogen is also accumulated in AD plaques [319; 354], and this can promote neurodegeneration [318].

As well as its general intra- and extra-cellular deposition, a common pathology in AD patients is the deposition of $A \beta$ in the walls of capillaries, arteries, and arterioles. This is known as cerebral amyloid angiopathy (CAA) [355]. Strickland and colleagues next showed [316], both In vitro and in vivo, that fibrin clots formed in the presence of $A \beta$ were structurally abnormal and resistant to degradation, and that lowering fibrinogen improved cognitive function (in mice). (It is also of interest that $A \beta$ promotes the binding of tissue plasminogen activator, which recognises cross-beta sheets [139; 356].) Thioflavin S (like thioflavin T, below) is a stain for amyloid fibrils based on their high $\beta$-sheet content [216; 357; 358]. Immunological staining of fibrinogen and thioflavin S staining of (presumed) A $\beta$ showed colocalisation [316; 317], though of course this would not have distinguished whether the fibrin too had adopted a $\beta$-sheet form.

Strickland and colleagues next showed [313] that $A \beta$ specifically interacts with fibrinogen $\left(K_{d} \sim 26\right.$ $\mathrm{nM}$ ), that the binding site is located near the $C$ terminus of the fibrinogen $\beta$-chain, and that the binding causes fibrinogen to oligomerise (albeit not to standard fibrin fibres) and to deposit. Although the $A \beta$ will bind to preformed clots, only when it is added before clotting do es it produce thinner fibres in tighter networks [320]; it also attenuates plasminogen binding (again consistent with the idea that it induces a structural change in the fibrinogen).

As is well known, the apoE4 allele is associated with a greater risk of AD; brains from AD cases homozygous for the APOE $\varepsilon 4$ allele showed increased deposition of fibrin(ogen), especially in CAA- and A $\beta$-positive blood vessels [359], fully consistent with the role of this process in cognitive decline. Similarly, pharmacological inhibition with a small molecule called Ru-505 of the fibrinogen$A \beta$ interaction both altered the clot morphology and arrested cognitive decline [314], implying the potential value of this target (which is also susceptible to enzymatic degradation [360]). Overall, the case for an important role of fibrin(ogen)'s interaction with $A \beta$ as part of the aetiology of $A D$ seems very well made. For our purposes, there are two chief questions: (i) what is the extent to which the 
bioRxiv preprint doi: https://doi.org/10.1101/054734; this version posted May 21, 2016. The copyright holder for this preprint (which was not certified by peer review) is the author/funder, who has granted bioRxiv a license to display the preprint in perpetuity. It is made available under aCC-BY 4.0 International license.

fibrin adopts an amyloid form when in complex with $A \beta$ ?, and (ii) is it more the fibrinogen that precipitates the $A \beta$ or the $A \beta$ that precipitates the fibrinogen?

\section{Small molecules that affect the nature of blood clotting and fibrin fibres in vitro}

The effects of small molecules (both those produced endogenously and introduced drugs) on the coagulation system represent a vast field, and arguably warrant a review of their own. However, we here briefly mention a few well-known molecules to illustrate how sensitive fibrin fibre morphology can be to their presence. Various endogenous (inflammatory) molecules, including stress hormones (including the hypothalamic-pituitary-adrenal axis activity) [361; 362], activate both the coagulation and fibrinolysis system resulting in net hypercoagulability. It is also wellknown that the inflammatory marker 'iron' may cause hypercoagulation in iron-overload diseases [363; 364]. We have reviewed in detail the effects of increased (endogenous) 'iron', including its effects on the coagulation system [148; 168; 169; 171; 338]. Many drugs introduced into the human body are known to influence the coagulation system; for a comprehensive list of the effects of various drugs on coagulation see [116]. The most well-known effect of various drugs on hypercoagulation is thrombotic microangiopathy, which is a pathology that results in thrombosis in capillaries and arterioles, due to an endothelial injury [365; 366]. Venous thromboembolism, is also a well-known result of the use of oral contraceptives [367; 368].

The above-mentioned molecules and others have direct effects on the fibrin fibre structure and packaging; these include molecules like S-nitrosoglutathione [369], iron and CO [162-164; 345], as well as oestrogen [370]. We have shown that addition of unliganded iron salts to fibrinogen, to healthy plasma, and/or to whole blood, causes pathological fibrin formation [271; 371; 372]; however, the addition of various iron chelators to this plasma [148; 171] results in a return of fibrin fibre structure to become similar to that of healthy fibrin. We also showed that adding chelators to blood/and or plasma from individuals with iron overload [168; 169; 373] similarly resulted in the return of the pathologic fibrin structure to that resembling healthy fibrin packaging. See Fig 10, where Fig $10 \mathrm{~A}$ shows the fibrin fibre structure of an individual with hereditary hemochromatosis and Fig $10 \mathrm{~B}$ when the chelators desferal (deferoxamine) is added to plasma of this patient.

Figure 10: A) Fibrin fibre structure of an individual with hereditary hemochromatosis; B) when desferal (deferoxamine) is added to plasma of this patient. Scale bar: $1 \mu \mathrm{m}$. 


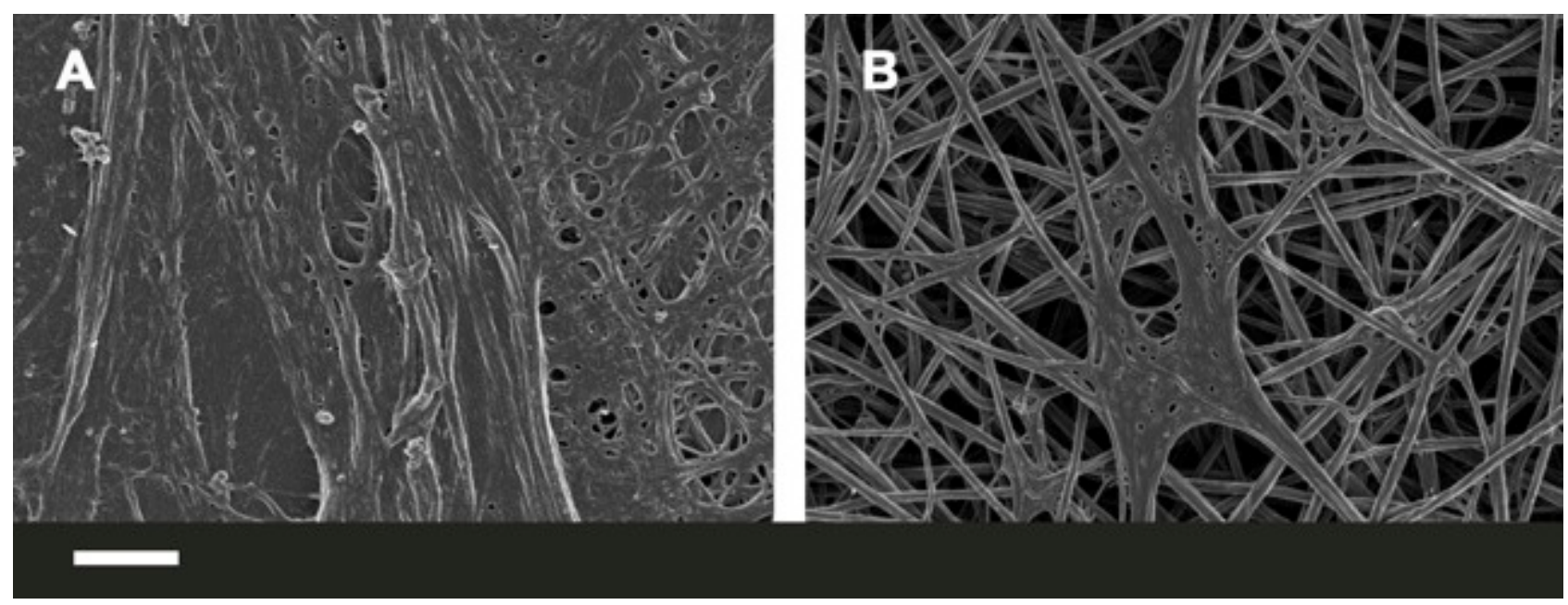

\section{Induction of clotting by added LPS (endotoxin)}

The very potent bacterial inflammagen, lipopolysaccharide (LPS) is well known to cause cytokine activation, and that this can cause hypercoagulation [374; 375]; this has been referred to as endotoxin-mediated hypercoagulation [376]. One mechanism of activation by LPS of the coagulation pathway is via tissue factor (TF) upregulation [377; 378]. Previously, it was found that LPS from Escherichia coli (100 ng. $\mathrm{mL}^{-1}$ ) activated the coagulation system when added to whole blood, via a complement- and CD14-dependent up-regulation of TF, leading to prothrombin activation and hypercoagulation [379]. Recently, we also found that minute levels of LPS (0.2 ng. $\mathrm{L}^{-}$ ${ }^{1}$ ) might bind directly to circulating plasma proteins (when added to plasma from healthy individuals), and also to pure fibrinogen, and that this (rapid) binding might also cause pathological changes in the coagulation process [170]. In our hands, the binding was virtually instantaneous and we confirmed the direct binding of LPS to pure fibrinogen using isothermal calorimetry. It was clear from thioflavin T measurements that LPS could massively affect the formation of $\beta$-sheets during fibrin packaging. Only a limited number of autocatalytic mechanisms can admit this, that which we favour (see below) being essentially a very raid form of amyloidogenesis and autocatalytic structural rearrangement to a $\beta$-rich conformation.

\section{Anomalous blood clotting involves genuine amyloid formation}

What had been determined earlier, and the same was true for changes in erythrocyte morphology [168; 169; 172], is that small molecules and the presence of various disease states could have massive effects on the morphology of fibrin as judged by (i) its distribution of fibre diameters and (ii) the formation of what we referred to as 'dense matted deposits', in which the fibres were typically much smaller than the normal (median $\sim 85 \mathrm{~nm}$ ). What we recently discovered [170] is that this was actually accompanied by genuine amyloid formation.

As part of a lengthy series on the role of true dormancy in bacterial physiology (e.g. [380-388]), we have recently come to recognise that a dormant blood microbiome is a significant contributor to a great many chronic, inflammatory diseases, not least by shedding highly inflammatory molecules 
bioRxiv preprint doi: https://doi org/101101/054734; this version posted May 21, 2016. The copyright holder for this preprint (which was not certified by peer review) is the author/funder, who has granted bioRxiv a license to display the preprint in perpetuity. It is made available under aCC-BY 4.0 International license.

such as lipopolysaccharide (LPS) [166; 167; 389]. This led us to assess [170] whether LPS had any effects on blood clotting directly.

It transpired [170] that quite miniscule concentrations (amounting to fewer than 1 molecule of freshly added LPS per $10^{8}$ molecules of fibrinogen!) had a massive effect on fibrinogen polymerisation to fibrin, including the production of (in many cases) the thinner fibres and 'dense matter deposits' seen in so many diseases. In particular, the use of the amyloid-detecting dye thioflavine T [188; 192-195; 197; 199; 200; 390-393] revealed a massive conversion of fibrin to a $\beta$ sheet-rich form.

\section{The extent of amplification of protein transitions by LPS can be mimicked by liquid crystals}

As phrased by Maji and colleagues [59], repeating motifs can translate a rather non-specific interaction into a specific one through cooperativity. This process can nowadays be observed directly [394], and amounts to potentially quite a massive amplification. In the example of our own mentioned above [170], with LPS freshly added to whole blood, platelet-poor plasma or fibrinogen solutions, the ratio of LPS:fibrinogen at which the LPS could induce amyloidogenesis was $\sim 1$ in $10^{8}$; this represents a truly massive amplification (see also [395]), and serves to help explain how very small numbers of bacteria secreting comparatively small amounts of LPS (albeit of potentially high concentration locally) can exert such a massive inflammagenic effect.

Interestingly, Lin and colleagues also showed that similarly tiny concentrations of LPS (less than 1 $\mathrm{ng} . \mathrm{L}^{-1}$ ) could also affect the cooperative conformation of millions of molecules in microdroplets of nematic liquid crystals ([396], and see [397]). The same was true for molecular mimics of LPS [398]. Indeed, different liquid crystals can also be used as 'biosensors' [399] to detect $\beta$-amyloid formation [400], protein-LPS interactions [401] and microvesicles [402].

\section{Chronic infection and amyloidogenesis}

As phrased by Michael Hann [403], 'unknown knowns' “... are those things that are known but have become unknown, either because we have never learnt them, or forgotten about them, or more dangerously chosen to ignore". Thus, in 1967, Kelényi could write "Development of new therapeutical measures in chronic infections has sharply reduced the incidence of secondary amyloidosis". In other words, the fact that chronic infection could induce amyloidosis was then so well known that it barely merited discussion! The same is true in comparable works of that era (e.g. [404]). Obviously it has since then been somewhat forgotten, despite the overwhelming evidence [331; 405] for a microbial component to $A D$, and to amyloidogenesis more generally [406]. Recently the role of dormant or latent microbes in chronic, inflammatory diseases more generally has come to the fore (e.g. [166; 167; 331; 389; 407-417]), and it is appropriate to recognise this and older literature (e.g. [418; 419]), some of which is still being rediscovered. Thus, Chlamydia pneumoniae induces Alzheimer-like amyloid plaques in the brains of BALB/c mice [420], while 
amyloid can also be induced by herpes simplex virus [421] and Borrelia [422-424]. In the present context it is of particular interest that LPS can induce the conversion of prion protein to its amyloidogenic form (provided the LPS concentration remains above its critical micelle concentration (CMC)) [25], and it can do this substoichiometrically. The natural bacterial production of amyloids themselves has also been reviewed [425-428].

\section{Serum amyloid A}

In a similar vein, 'serum amyloid A' [429] describes a heterogeneous family of apolipoproteins [430] (and variants [431]) that form amyloid fibrils in the blood, typically in response to inflammation or infection [432-434], binding retinol in the process [435]. To this end, this rather understudied series of proteins may provide very useful biomarkers for chronic infection/sepsis, for which it is in fact a well-established (and potent) biomarker (e.g. [406; 432; 433; 435-447]). Interestingly, and in a manner akin to that of prions, it is able to catalyse its own $\alpha$-to- $\beta$-type conformational transitions (e.g. $[67 ; 69 ; 70 ; 75 ; 77 ; 448 ; 449]$ ), although the kinetics are rather sluggish compared to those of blood clotting.

\section{Possible treatments for coagulopathies in the light of their role in amyloidogenesis}

Recognising that 'dense matted deposits' are actually amyloid encourages one to access the literature designed to stop or reverse amyloidogenesis in other fields such as Alzheimer's disease (e.g. [84; 109; 111; 314; 450-460], and see also [461-464]) or for transthyretin [395; 465], and thus it will be of interest to assess candidate anti-amyloidogenic molecules in the blood system, where it is not, at least, necessary for them to cross the blood-brain barrier (see [218-220]).

In a complementary vein, if (anomalous) fibrin clot formation is significant in AD one might suppose that inhibiting it might be of value, and it is [314]. One might also expect that anticoagulant therapies might show benefit, and there are some significant hints that this too might indeed be the case [466-470], to the extent that this would seem to be well worth exploring properly.

Since the levels of fibrinogen themselves seem to correlate with a propensity for AD (see above), and indeed for hypertension [471-474], lowering them to more appropriate levels would seem to be a desirable aim in itself.

\section{Quo vadis? - systems strategies}

We have summarised much of the evidence to the effect that under some circumstances the fibrin fibres formed by fibrinogen polymerisation are in fact amyloid in character (Fig 11). This opens up the field to testing this under the many different disease circumstances where this might be suspected, whether as a diagnostic or a prognostic. Easy predictions are that the clots seen after stroke and in any other hypercoagulable conditions will be amyloid and thus stainable with 
thioflavin T. The many established methods for $\beta$-amyloid detection include spectroscopies (e.g. Xrays [475], NMR [476; 477], circular dichroism, neutron, vibrational) and microscopies (including appropriate stains (Fig 11 and above)) will be of value in detection. Similarly, a huge plethora of small molecule studies will clearly be of value in seeking to modulate such amyloid formation. As is common in modern biology, strategies for pharmacological inhibition are usually done piecemeal on the basis of specific hypotheses about individual targets. Clearly this must change. We have highlighted several 'non-traditional' targets here (e.g. iron metabolism, blood clotting, fibrinogen$A \beta$ interactions, anti-amyloids) but they have only been studied singly.

Figure 11: An elementary systems biology model of how iron dysregulation can stimulate dormant bacterial growth that can in turn lead to antigen production (e.g. of LPS) that can then trigger inflammation, leading to $\beta \square$ amyloid formation in fibrin and ultimately to cell death. 


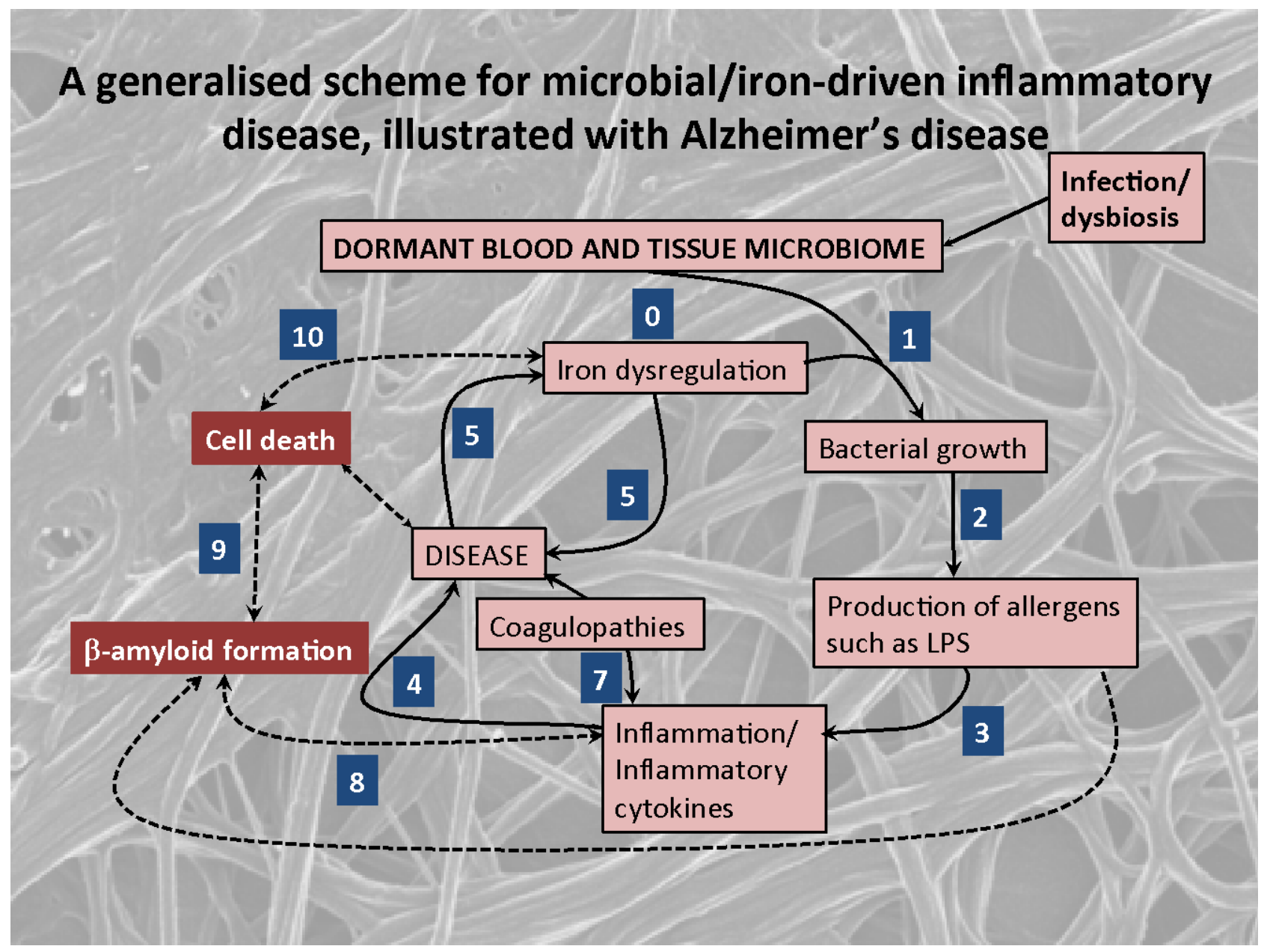

From a network or systems pharmacology perspective (e.g. [478-482]), we either need polypharmacology (one drug, multiple targets, e.g. [220; 482-493] or suitably combined cocktails of individual drugs (e.g. [494-498]). Armed with these, and based on established mechanisms of action that involve fibrin(ogen), we may strongly hope to delay the progression of amyloidogenic diseases in our ageing populations.

In a related vein, we would be remiss not to recognise that an understanding of how small trigger events can effect massive conformational changes in designed proteins has potentially massive benefits for synthetic biotechnology [499; 500]. Nakano and colleagues provide a very nice biomaterials example with barnacle glue [501].

Overall, the crux of the review is that we have indicated that many more proteins than perhaps currently recognised, and in particular fibrin(ogen), can form genuine amyloid structures that are likely to be significant in toxicity and disease; clarifying the link between their essential molecular structure/conformation and their disease-causing potential is now key, and the fields of blood clotting and amloidogenesis can learn much from each other to mutual advantage. 
bioRxiv preprint doi: https://doi org/10.1101/054734; this version posted May 21, 2016. The copyright holder for this preprint (which was not certified by peer review) is the author/funder, who has granted bioRxiv a license to display the preprint in perpetuity. It is made available under aCC-BY 4.0 International license.

Acknowledgments. We thank the Biotechnology and Biological Sciences Research Council (grant BB/L025752/1) as well as the National Research Foundation (NRF) of South Africa for supporting this collaboration. This is also a contribution from the Manchester Centre for Synthetic Biology of Fine and Speciality Chemicals (SYNBIOCHEM) (BBSRC grant BB/M017702/1). We thank Dr Steve O'Hagan for the analyses underpinning Fig 8. 
bioRxiv preprint doi: $\mathrm{https}$ //doi org/10.1101/054734; this version posted May 21 2016. The copyright holder for this preprint (which was not certified by peer review) is the author/funder, who has granted bioRxiv a license to display the preprint in perpetuity. It is made available under aCC-BY 4.0 International license.

\section{Legends to figures}

Figure 1: $\operatorname{PrP}^{c}$ conformation of human prion protein (1HJM at PDB).

Figure 2: Kinetic isolation of $\mathrm{PrP}^{\mathrm{Sc}}$ from $\mathrm{PrP}^{\mathrm{C}}$ (based on [28].

Figure 3: The coagulation cascade showing the final conversion of fibrinogen to fibrin.

Figure 4: Diagrammatic representation of fibrinogen packaging into the final product, the crosslinked fibrin mesh.

Figure 5: The $\alpha$-helices to $\beta$-sheets phase transition in fibrin formation under deformation of e.g. low (healthy coagulation) and high force (pathological coagulation) (adapted from [129]).

Figure 6: Examples of amyloid staining reagents.

Figure 7: Fibrin fibres from a healthy individual (A) and a thromboembolic and stroke individual (B), stained with ThT (5 $\mu \mathrm{M}$ final concentration) and viewed using a confocal microscope. Scale bar: $10 \mu \mathrm{m}$.

Figure 8: The three endogenous metabolites and marketed drugs most closely related to PIB, as assessed using the MACCS encoding [233] and the Tanimoto distance.

Figure 9: Representative micrographs of different inflammatory conditions. A) Healthy fibrin fibre structure; B) thromboembolic stroke; C) Alzheimer's type dementia; D) Type II diabetes. White arrows: fine netted areas; Red arrow: areas where fibrin fibres are thicker. Scale bar: 1 $\mu \mathrm{m}$.

Figure 10: A) Fibrin fibre structure of an individual with hereditary hemochromatosis; B) when desferal (deferoxamine) is added to plasma of this patient. Scale bar: $1 \mu \mathrm{m}$.

Figure 11: An elementary systems biology model of how iron dysregulation can stimulate dormant bacterial growth that can in turn lead to antigen production (e.g. of LPS) that can then trigger inflammation, leading to amyloid formation in fibrin and ultimately to cell death.

Table 1: TEG parameters typically generated for whole blood and platelet poor plasma [160; 161].

Table 2: Wavelengths that have commonly been used for excitation and emission when assessing Thioflavin T interaction with $\beta$-amyloids. 
bioRxiv preprint doi: https://doi.org/10.1101/054734; this version posted May 21, 2016. The copyright holder for this preprint (which was not certified by peer review) is the author/funder, who has granted bioRxiv a license to display the preprint in perpetuity. It is made available under aCC-BY 4.0 International license.

\section{References}

[1] Weisel, J. W. (2011). Stressed fibrin lysis. J Thromb Haemost 9, 977-8.

[2] Anfinsen, C. B., Haber, E., Sela, M. \& White, F. H. (1961). The kinetics of formation of native ribonuclease during oxidation of the reduced polypeptide chain. Proc. Natl. acad. Sci. 47, 1309-1314.

[3] Anfinsen, C. B. (1973). Principles that govern the folding of protein chains. Science 181, 223230.

[4] Kell, D. B. (2012). Scientific discovery as a combinatorial optimisation problem: how best to navigate the landscape of possible experiments? Bioessays 34, 236-244.

[5] Verma, A. \& Wenzel, W. (2009). A free-energy approach for all-atom protein simulation. Biophys J 96, 3483-94.

[6] Piana, S., Lindorff-Larsen, K. \& Shaw, D. E. (2012). Protein folding kinetics and thermodynamics from atomistic simulation. Proc Natl Acad Sci 109, 17845-17850.

[7] Piana, S., Lindorff-Larsen, K. \& Shaw, D. E. (2013). Atomic-level description of ubiquitin folding. Proc Natl Acad Sci 110, 5915-20.

[8] Piana, S., Klepeis, J. L. \& Shaw, D. E. (2014). Assessing the accuracy of physical models used in protein-folding simulations: quantitative evidence from long molecular dynamics simulations. Curr Opin Struct Biol 24, 98-105.

[9] Prusiner, S. B. (1998). Prions. Proc. Natl. Acad. Sci. 95, 13363-13383.

[10] Aguzzi, A. \& Calella, A. M. (2009). Prions: protein aggregation and infectious diseases. Physiol Rev 89, 1105-52.

[11] Caughey, B., Baron, G. S., Chesebro, B. \& Jeffrey, M. (2009). Getting a grip on prions: oligomers, amyloids, and pathological membrane interactions. Annu Rev Biochem 78, 177204.

[12] Colby, D. W. \& Prusiner, S. B. (2011). Prions. Cold Spring Harb Perspect Biol 3, a006833.

[13] Sipe, J. D. \& Cohen, A. S. (2000). Review: history of the amyloid fibril. J Struct Biol 130, 88-98.

[14] Eisenberg, D. \& Jucker, M. (2012). The amyloid state of proteins in human diseases. Cell 148, 1188-203.

[15] Pan, K. M., Baldwin, M., Nguyen, J., Gasset, M., Serban, A., Groth, D., Mehlhorn, I., Huang, Z., Fletterick, R. J., Cohen, F. E. \& et al. (1993). Conversion of alpha-helices into betasheets features in the formation of the scrapie prion proteins. Proc Natl Acad Sci U S A 90, 10962-6.

[16] Baldwin, M. A., Pan, K. M., Nguyen, J., Huang, Z., Groth, D., Serban, A., Gasset, M., Mehlhorn, I., Fletterick, R. J., Cohen, F. E. \& et al. (1994). Spectroscopic characterization of conformational differences between $\operatorname{PrP}^{\mathrm{C}}$ and $\operatorname{PrP}^{\mathrm{Sc}}$ : an alpha-helix to beta-sheet transition. Philos Trans R Soc Lond B Biol Sci 343, 435-41.

[17] Harrison, P. M., Bamborough, P., Daggett, V., Prusiner, S. B. \& Cohen, F. E. (1997). The prion folding problem. Curr Opin Struct Biol 7, 53-9.

[18] Groveman, B. R., Dolan, M. A., Taubner, L. M., Kraus, A., Wickner, R. B. \& Caughey, B. (2014). Parallel in-register intermolecular beta-sheet architectures for prion-seeded prion protein (PrP) amyloids. J Biol Chem 289, 24129-42.

[19] Ow, S. Y. \& Dunstan, D. E. (2014). A brief overview of amyloids and Alzheimer's disease. Protein Sci 23, 1315-31.

[20] Tycko, R. \& Wickner, R. B. (2013). Molecular structures of amyloid and prion fibrils: consensus versus controversy. Acc Chem Res 46, 1487-96.

[21] Grassi, J., Creminon, C., Frobert, Y., Fretier, P., Turbica, I., Rezaei, H., Hunsmann, G., Comoy, E. \& Deslys, J. P. (2000). Specific determination of the proteinase K-resistant form of the prion protein using two-site immunometric assays. Application to the post-mortem diagnosis of BSE. Arch. Virol., 197-205.

[22] Mishra, R. S., Basu, S., Gu, Y., Luo, X., Zou, W. Q., Mishra, R., Li, R., Chen, S. G., Gambetti, P., Fujioka, H. \& Singh, N. (2004). Protease-resistant human prion protein and ferritin are cotransported across Caco-2 epithelial cells: implications for species barrier in prion uptake from the intestine. J Neurosci 24, 11280-90. 
bioRxiv preprint doi: https://doi.org/10.1101/054734; this version posted May 21, 2016. The copyright holder for this preprint (which was not certified by peer review) is the author/funder, who has granted bioRxiv a license to display the preprint in perpetuity. It is made available under aCC-BY 4.0 International license.

[23] Basu, S., Mohan, M. L., Luo, X., Kundu, B., Kong, Q. \& Singh, N. (2007). Modulation of proteinase K-resistant prion protein in cells and infectious brain homogenate by redox iron: implications for prion replication and disease pathogenesis. Mol Biol Cell 18, 3302-12.

[24] Saverioni, D., Notari, S., Capellari, S., Poggiolini, I., Giese, A., Kretzschmar, H. A. \& Parchi, P. (2013). Analyses of protease resistance and aggregation state of abnormal prion protein across the spectrum of human prions. J Biol Chem 288, 27972-85.

[25] Saleem, F., Bjorndahl, T. C., Ladner, C. L., Perez-Pineiro, R., Ametaj, B. N. \& Wishart, D. S. (2014). Lipopolysaccharide induced conversion of recombinant prion protein. Prion 8, 221232.

[26] Saá, P. \& Cervenakova, L. (2015). Protein misfolding cyclic amplification (PMCA): Current status and future directions. Virus Res 207, 47-61.

[27] Silva, C. J., Vazquez-Fernández, E., Onisko, B. \& Requena, J. R. (2015). Proteinase K and the structure of $\mathrm{PrP}^{\mathrm{Sc}}$. The good, the bad and the ugly. Virus Res 207, 120-6.

[28] Cohen, F. E. \& Prusiner, S. B. (1998). Pathologic conformations of prion proteins. Annu Rev Biochem 67, 793-819.

[29] Henzler Wildman, K. A., Lee, D. K. \& Ramamoorthy, A. (2002). Determination of alpha-helix and beta-sheet stability in the solid state: a solid-state NMR investigation of poly(L-alanine). Biopolymers 64, 246-54.

[30] Foguel, D., Suarez, M. C., Ferrao-Gonzales, A. D., Porto, T. C., Palmieri, L., Einsiedler, C. M., Andrade, L. R., Lashuel, H. A., Lansbury, P. T., Kelly, J. W. \& Silva, J. L. (2003).

Dissociation of amyloid fibrils of alpha-synuclein and transthyretin by pressure reveals their reversible nature and the formation of water-excluded cavities. Proc Natl Acad Sci U S A 100, 9831-6.

[31] Sipe, J. D., Benson, M. D., Buxbaum, J. N., Ikeda, S., Merlini, G., Saraiva, M. J. \& Westermark, P. (2014). Nomenclature 2014: Amyloid fibril proteins and clinical classification of the amyloidosis. Amyloid 21, 221-4.

[32] Tycko, R. (2014). Physical and structural basis for polymorphism in amyloid fibrils. Protein Sci 23, 1528-39.

[33] Chien, P., DePace, A. H., Collins, S. R. \& Weissman, J. S. (2003). Generation of prion transmission barriers by mutational control of amyloid conformations. Nature 424, 948-51.

[34] Chien, P., Weissman, J. S. \& DePace, A. H. (2004). Emerging principles of conformationbased prion inheritance. Annu Rev Biochem 73, 617-56.

[35] Petkova, A. T., Leapman, R. D., Guo, Z., Yau, W. M., Mattson, M. P. \& Tycko, R. (2005). Selfpropagating, molecular-level polymorphism in Alzheimer's beta-amyloid fibrils. Science 307, 262-5.

[36] Weissmann, C. (2005). Birth of a prion: spontaneous generation revisited. Cell 122, 165-8.

[37] Collinge, J. \& Clarke, A. R. (2007). A general model of prion strains and their pathogenicity. Science 318, 930-6.

[38] Toyama, B. H., Kelly, M. J. S., Gross, J. D. \& Weissman, J. S. (2007). The structural basis of yeast prion strain variants. Nature $449,233-7$.

[39] Makarava, N. \& Baskakov, I. V. (2008). The same primary structure of the prion protein yields two distinct self-propagating states. J Biol Chem 283, 15988-96.

[40] Wiltzius, J. J. W., Landau, M., Nelson, R., Sawaya, M. R., Apostol, M. I., Goldschmidt, L., Soriaga, A. B., Cascio, D., Rajashankar, K. \& Eisenberg, D. (2009). Molecular mechanisms for protein-encoded inheritance. Nat Struct Mol Biol 16, 973-8.

[41] Collinge, J. (2010). Prion strain mutation and selection. Science 328, 1111-2.

[42] Greenwald, J. \& Riek, R. (2010). Biology of amyloid: structure, function, and regulation. Structure 18, 1244-60.

[43] Cushman, M., Johnson, B. S., King, O. D., Gitler, A. D. \& Shorter, J. (2010). Prion-like disorders: blurring the divide between transmissibility and infectivity. J Cell Sci 123, 1191201.

[44] Toyama, B. H. \& Weissman, J. S. (2011). Amyloid structure: conformational diversity and consequences. Annu Rev Biochem 80, 557-85.

[45] Poggiolini, I., Saverioni, D. \& Parchi, P. (2013). Prion protein misfolding, strains, and neurotoxicity: an update from studies on mammalian prions. Int J Cell Biol 2013, 910314.

[46] Gill, A. C. (2014). beta-hairpin-mediated formation of structurally distinct multimers of neurotoxic prion peptides. PLoS One 9, e87354. 
bioRxiv preprint doi: https://doi.org/10.1101/054734; this version posted May 21, 2016. The copyright holder for this preprint (which was not certified by peer review) is the author/funder, who has granted bioRxiv a license to display the preprint in perpetuity. It is made available under aCC-BY 4.0 International license.

[47] Sano, K., Atarashi, R., Ishibashi, D., Nakagaki, T., Satoh, K. \& Nishida, N. (2014). Conformational properties of prion strains can be transmitted to recombinant prion protein fibrils in real-time quaking-induced conversion. $J$ Virol 88, 11791-801.

[48] Wickner, R. B., Edskes, H. K., Bateman, D. A., Kelly, A. C., Gorkovskiy, A., Dayani, Y. \& Zhou, A. (2014). Amyloid diseases of yeast: prions are proteins acting as genes. Essays Biochem 56, 193-205.

[49] Le, N. T., Narkiewicz, J., Aulic, S., Salzano, G., Tran, H. T., Scaini, D., Moda, F., Giachin, G. \& Legname, G. (2015). Synthetic prions and other human neurodegenerative proteinopathies. Virus Res 207, 25-37.

[50] Moda, F., Le, T. N., Aulic, S., Bistaffa, E., Campagnani, I., Virgilio, T., Indaco, A., Palamara, L., Andreoletti, O., Tagliavini, F. \& Legname, G. (2015). Synthetic prions with novel strainspecified properties. PLoS Pathog 11, e1005354.

[51] Tycko, R. (2015). Amyloid polymorphism: structural basis and neurobiological relevance. Neuron 86, 632-45.

[52] Fändrich, M., Meinhardt, J. \& Grigorieff, N. (2009). Structural polymorphism of Alzheimer Abeta and other amyloid fibrils. Prion 3, 89-93.

[53] Meinhardt, J., Sachse, C., Hortschansky, P., Grigorieff, N. \& Fändrich, M. (2009). Abeta(1-40) fibril polymorphism implies diverse interaction patterns in amyloid fibrils. $\mathrm{J} \mathrm{Mol} \mathrm{Biol} \mathrm{386,}$ 869-77.

[54] Kodali, R., Williams, A. D., Chemuru, S. \& Wetzel, R. (2010). Abeta(1-40) forms five distinct amyloid structures whose beta-sheet contents and fibril stabilities are correlated. $\mathrm{J} \mathrm{Mol} \mathrm{Biol}$ 401, 503-17.

[55] Reinke, A. A. \& Gestwicki, J. E. (2011). Insight into amyloid structure using chemical probes. Chem Biol Drug Des 77, 399-411.

[56] Kammerer, R. A., Kostrewa, D., Zurdo, J., Detken, A., Garcia-Echeverría, C., Green, J. D., Müller, S. A., Meier, B. H., Winkler, F. K., Dobson, C. M. \& Steinmetz, M. O. (2004). Exploring amyloid formation by a de novo design. Proc Natl Acad Sci U S A 101, 4435-40.

[57] Kammerer, R. A. \& Steinmetz, M. O. (2006). De novo design of a two-stranded coiled-coil switch peptide. J Struct Biol 155, 146-53.

[58] Verel, R., Tomka, I. T., Bertozzi, C., Cadalbert, R., Kammerer, R. A., Steinmetz, M. O. \& Meier, B. H. (2008). Polymorphism in an amyloid-like fibril-forming model peptide. Angew Chem Int Ed Engl 47, 5842-5.

[59] Maji, S. K., Wang, L., Greenwald, J. \& Riek, R. (2009). Structure-activity relationship of amyloid fibrils. FEBS Lett 583, 2610-7.

[60] Chiti, F. \& Dobson, C. M. (2006). Protein misfolding, functional amyloid, and human disease. Annu Rev Biochem 75, 333-66.

[61] Herczenik, E. \& Gebbink, M. F. B. G. (2008). Molecular and cellular aspects of protein misfolding and disease. FASEB J 22, 2115-33.

[62] Rambaran, R. N. \& Serpell, L. C. (2008). Amyloid fibrils: abnormal protein assembly. Prion 2, 112-7.

[63] Moreno-Gonzalez, I. \& Soto, C. (2011). Misfolded protein aggregates: Mechanisms, structures and potential for disease transmission. Seminars in Cell \& Developmental Biology 22, 482487.

[64] Olanow, C. W. \& Brundin, P. (2013). Parkinson's disease and alpha synuclein: is Parkinson's disease a prion-like disorder? Mov Disord 28, 31-40.

[65] Knowles, T. P. J., Vendruscolo, M. \& Dobson, C. M. (2014). The amyloid state and its association with protein misfolding diseases. Nature Reviews Molecular Cell Biology 15, 384-396.

[66] Tipping, K. W., van Oosten-Hawle, P., Hewitt, E. W. \& Radford, S. E. (2015). Amyloid Fibres: Inert End-Stage Aggregates or Key Players in Disease? Trends Biochem Sci 40, 719-27.

[67] Lundmark, K., Westermark, G. T., Olsen, A. \& Westermark, P. (2005). Protein fibrils in nature can enhance amyloid protein $A$ amyloidosis in mice: Cross-seeding as a disease mechanism. Proc Natl Acad Sci U S A 102, 6098-102.

[68] Soto, C., Estrada, L. \& Castilla, J. (2006). Amyloids, prions and the inherent infectious nature of misfolded protein aggregates. Trends Biochem Sci 31, 150-5. 
bioRxiv preprint doi: https://doi.org/10.1101/054734; this version posted May 21, 2016. The copyright holder for this preprint (which was not certified by peer review) is the author/funder, who has granted bioRxiv a license to display the preprint in perpetuity. It is made available under aCC-BY 4.0 International license.

[69] Liu, Y., Cui, D., Hoshii, Y., Kawano, H., Une, Y., Gondo, T. \& Ishihara, T. (2007). Induction of murine AA amyloidosis by various homogeneous amyloid fibrils and amyloid-like synthetic peptides. Scand J Immunol 66, 495-500.

[70] Westermark, P., Lundmark, K. \& Westermark, G. T. (2009). Fibrils from designed non-amyloidrelated synthetic peptides induce AA-amyloidosis during inflammation in an animal model. PLoS One 4, e6041.

[71] Frost, B. \& Diamond, M. I. (2010). Prion-like mechanisms in neurodegenerative diseases. Nat Rev Neurosci 11, 155-9.

[72] Ono, K., Takahashi, R., Ikeda, T. \& Yamada, M. (2012). Cross-seeding effects of amyloid beta-protein and alpha-synuclein. J Neurochem 122, 883-90.

[73] Morales, R., Moreno-Gonzalez, I. \& Soto, C. (2013). Cross-Seeding of Misfolded Proteins: Implications for Etiology and Pathogenesis of Protein Misfolding Diseases. PLoS Pathog 9.

[74] Hu, R., Zhang, M., Chen, H., Jiang, B. \& Zheng, J. (2015). Cross-Seeding Interaction between beta-Amyloid and Human Islet Amyloid Polypeptide. ACS Chem Neurosci 6, 1759-68.

[75] Murakami, T., Ishiguro, N. \& Higuchi, K. (2014). Transmission of systemic AA amyloidosis in animals. Vet Pathol 51, 363-71.

[76] Morales, R., Callegari, K. \& Soto, C. (2015). Prion-like features of misfolded Abeta and tau aggregates. Virus Res 207, 106-12.

[77] Murakami, T., Inoshima, Y. \& Ishiguro, N. (2015). Systemic AA amyloidosis as a prion-like disorder. Virus Res 207, 76-81.

[78] Zhang, M., Hu, R., Chen, H., Chang, Y., Ma, J., Liang, G., Mi, J., Wang, Y. \& Zheng, J. (2015). Polymorphic cross-seeding amyloid assemblies of amyloid-beta and human islet amyloid polypeptide. Phys Chem Chem Phys 17, 23245-56.

[79] Aguzzi, A. \& Haass, C. (2003). Games played by rogue proteins in prion disorders and Alzheimer's disease. Science 302, 814-8.

[80] Prusiner, S. B., Woerman, A. L., Mordes, D. A., Watts, J. C., Rampersaud, R., Berry, D. B., Patel, S., Oehler, A., Lowe, J. K., Kravitz, S. N., Geschwind, D. H., Glidden, D. V., Halliday, G. M., Middleton, L. T., Gentleman, S. M., Grinberg, L. T. \& Giles, K. (2015). Evidence for alpha-synuclein prions causing multiple system atrophy in humans with parkinsonism. Proc Natl Acad Sci U S A 112, E5308-17.

[81] Ashe, K. H. \& Aguzzi, A. (2013). Prions, prionoids and pathogenic proteins in Alzheimer disease. Prion 7, 55-9.

[82] Aguzzi, A. \& Lakkaraju, A. K. K. (2016). Cell Biology of Prions and Prionoids: A Status Report. Trends Cell Biol 26, 40-51.

[83] Sponarova, J., Nyström, S. N. \& Westermark, G. T. (2008). AA-amyloidosis can be transferred by peripheral blood monocytes. PLoS One 3, e3308.

[84] Eisele, Y. S., Monteiro, C., Fearns, C., Encalada, S. E., Wiseman, R. L., Powers, E. T. \& Kelly, J. W. (2015). Targeting protein aggregation for the treatment of degenerative diseases. Nat Rev Drug Discov 14, 759-80.

[85] Soto, C. (2012). Transmissible Proteins: Expanding the Prion Heresy. Cell 149, 968-977.

[86] Nielsen, L., Frokjaer, S., Carpenter, J. F. \& Brange, J. (2001). Studies of the structure of insulin fibrils by Fourier transform infrared (FTIR) spectroscopy and electron microscopy. $J$ Pharm Sci 90, 29-37.

[87] Nielsen, L., Khurana, R., Coats, A., Frokjaer, S., Brange, J., Vyas, S., Uversky, V. N. \& Fink, A. L. (2001). Effect of environmental factors on the kinetics of insulin fibril formation: elucidation of the molecular mechanism. Biochemistry 40, 6036-46.

[88] Nielsen, L., Frokjaer, S., Brange, J., Uversky, V. N. \& Fink, A. L. (2001). Probing the mechanism of insulin fibril formation with insulin mutants. Biochemistry 40, 8397-409.

[89] Wang, W. (2005). Protein aggregation and its inhibition in biopharmaceutics. Int J Pharm 289, 1-30.

[90] Ventura, S. \& Villaverde, A. (2006). Protein quality in bacterial inclusion bodies. Trends Biotechnol 24, 179-85.

[91] Morell, M., Bravo, R., Espargaró, A., Sisquella, X., Avilés, F. X., Fernàndez-Busquets, X. \& Ventura, S. (2008). Inclusion bodies: specificity in their aggregation process and amyloidlike structure. Biochim Biophys Acta 1783, 1815-25.

[92] Wang, L., Maji, S. K., Sawaya, M. R., Eisenberg, D. \& Riek, R. (2008). Bacterial inclusion bodies contain amyloid-like structure. PLoS Biol 6, e195. 
bioRxiv preprint doi: https://doi.org/10.1101/054734; this version posted May 21, 2016. The copyright holder for this preprint (which was not certified by peer review) is the author/funder, who has granted bioRxiv a license to display the preprint in perpetuity. It is made available under aCC-BY 4.0 International license.

[93] de Groot, N. S., Sabate, R. \& Ventura, S. (2009). Amyloids in bacterial inclusion bodies. Trends Biochem Sci 34, 408-16.

[94] Wang, L. (2009). Towards revealing the structure of bacterial inclusion bodies. Prion 3, 13945.

[95] Fowler, D. M., Koulov, A. V., Balch, W. E. \& Kelly, J. W. (2007). Functional amyloid--from bacteria to humans. Trends Biochem Sci 32, 217-24.

[96] Tsemekhman, K., Goldschmidt, L., Eisenberg, D. \& Baker, D. (2007). Cooperative hydrogen bonding in amyloid formation. Protein Sci 16, 761-4.

[97] Serpell, L. C. (2000). Alzheimer's amyloid fibrils: structure and assembly. Biochim Biophys Acta 1502, 16-30.

[98] Stromer, T. \& Serpell, L. C. (2005). Structure and morphology of the Alzheimer's amyloid fibril. Microscopy Research and Technique 67, 210-217.

[99] Morris, K. L. \& Serpell, L. C. (2012). X-ray fibre diffraction studies of amyloid fibrils. Methods Mol Biol 849, 121-35.

[100] Langkilde, A. E., Morris, K. L., Serpell, L. C., Svergun, D. I. \& Vestergaard, B. (2015). The architecture of amyloid-like peptide fibrils revealed by X-ray scattering, diffraction and electron microscopy. Acta Crystallogr D Biol Crystallogr 71, 882-95.

[101] Alexander, P. A., He, Y., Chen, Y., Orban, J. \& Bryan, P. N. (2009). A minimal sequence code for switching protein structure and function. Proc Natl Acad Sci 106, 21149-54.

[102] Silva, J. L., Vieira, T. C. R. G., Gomes, M. P. B., Rangel, L. P., Scapin, S. M. N. \& Cordeiro, Y. (2011). Experimental approaches to the interaction of the prion protein with nucleic acids and glycosaminoglycans: Modulators of the pathogenic conversion. Methods 53, 306-17.

[103] Groveman, B. R., Kraus, A., Raymond, L. D., Dolan, M. A., Anson, K. J., Dorward, D. W. \& Caughey, B. (2015). Charge neutralization of the central lysine cluster in prion protein (PrP) promotes PrP(Sc)-like folding of recombinant PrP amyloids. J Biol Chem 290, 1119-28.

[104] Ladner-Keay, C. L., Griffith, B. J. \& Wishart, D. S. (2014). Shaking alone induces de novo conversion of recombinant prion proteins to beta-sheet rich oligomers and fibrils. PLoS One 9, e98753.

[105] Klement, K., Wieligmann, K., Meinhardt, J., Hortschansky, P., Richter, W. \& Fändrich, M. (2007). Effect of different salt ions on the propensity of aggregation and on the structure of Alzheimer's abeta(1-40) amyloid fibrils. J Mol Biol 373, 1321-33.

[106] Gursky, O. (2015). Lipids in protein misfolding. In Adv Exp Med Biol, vol. 855. Springer, New York.

[107] Levine, D. J., Stöhr, J., Falese, L. E., Ollesch, J., Wille, H., Prusiner, S. B. \& Long, J. R. (2015). Mechanism of scrapie prion precipitation with phosphotungstate anions. ACS Chem Biol 10, 1269-77.

[108] Chiti, F., Webster, P., Taddei, N., Clark, A., Stefani, M., Ramponi, G. \& Dobson, C. M. (1999). Designing conditions for in vitro formation of amyloid protofilaments and fibrils. Proc Natl Acad Sci U S A 96, 3590-4.

[109] Doig, A. J. \& Derreumaux, P. (2015). Inhibition of protein aggregation and amyloid formation by small molecules. Curr Opin Struct Biol 30, 50-6.

[110] Krishnan, R., Tsubery, H., Proschitsky, M. Y., Asp, E., Lulu, M., Gilead, S., Gartner, M., Waltho, J. P., Davis, P. J., Hounslow, A. M., Kirschner, D. A., Inouye, H., Myszka, D. G., Wright, J., Solomon, B. \& Fisher, R. A. (2014). A bacteriophage capsid protein provides a general amyloid interaction motif (GAIM) that binds and remodels misfolded protein assemblies. J Mol Biol 426, 2500-19.

[111] Jucker, M. \& Walker, L. C. (2013). Self-propagation of pathogenic protein aggregates in neurodegenerative diseases. Nature 501, 45-51.

[112] Walton, B. L., Byrnes, J. R. \& Wolberg, A. S. (2015). Fibrinogen, red blood cells, and factor XIII in venous thrombosis. J Thromb Haemost 13 Suppl 1, S208-15.

[113] Neeves, K. B., Illing, D. A. \& Diamond, S. L. (2010). Thrombin flux and wall shear rate regulate fibrin fiber deposition state during polymerization under flow. Biophys $\mathrm{J}$ 98, 134452.

[114] Ferri, F., Greco, M., Arcovito, G., De Spirito, M. \& Rocco, M. (2002). Structure of fibrin gels studied by elastic light scattering techniques: dependence of fractal dimension, gel crossover length, fiber diameter, and fiber density on monomer concentration. Phys Rev $E$ 66, 011913. 
bioRxiv preprint doi: https://doi.org/10.1101/054734; this version posted May 21, 2016. The copyright holder for this preprint (which was not certified by peer review) is the author/funder, who has granted bioRxiv a license to display the preprint in perpetuity. It is made available under aCC-BY 4.0 International license.

[115] Guthold, M., Liu, W., Sparks, E. A., Jawerth, L. M., Peng, L., Falvo, M., Superfine, R., Hantgan, R. R. \& Lord, S. T. (2007). A comparison of the mechanical and structural properties of fibrin fibers with other protein fibers. Cell Biochem Biophys 49, 165-81.

[116] Undas, A. \& Ariëns, R. A. S. (2011). Fibrin clot structure and function: a role in the pathophysiology of arterial and venous thromboembolic diseases. Arterioscler Thromb Vasc Biol 31, e88-99.

[117] Litvinov, R. I., Yakovlev, S., Tsurupa, G., Gorkun, O. V., Medved, L. \& Weisel, J. W. (2007). Direct evidence for specific interactions of the fibrinogen alphaC-domains with the central $E$ region and with each other. Biochemistry 46, 9133-42.

[118] Litvinov, R. I., Faizullin, D. A., Zuev, Y. F. \& Weisel, J. W. (2012). The alpha-helix to betasheet transition in stretched and compressed hydrated fibrin clots. Biophys J 103, 1020-7.

[119] Yeromonahos, C., Polack, B. \& Caton, F. (2010). Nanostructure of the fibrin clot. Biophys J 99, 2018-27.

[120] Yang, Z., Kollman, J. M., Pandi, L. \& Doolittle, R. F. (2001). Crystal structure of native chicken fibrinogen at $2.7 \AA$ resolution. Biochemistry 40, 12515-23.

[121] Weisel, J. W. (1986). Fibrin assembly. Lateral aggregation and the role of the two pairs of fibrinopeptides. Biophys J 50, 1079-93.

[122] Ferry, J. D. \& Morrison, P. R. (1947). Preparation and properties of serum and plasma proteins. IX. Human fibrin in the form of an elastic film. J Am Chem Soc 69, 400-9.

[123] Fowler, W. E., Hantgan, R. R., Hermans, J. \& Erickson, H. P. (1981). Structure of the fibrin protofibril. Proc Natl Acad Sci U S A 78, 4872-6.

[124] Dickneite, G., Herwald, H., Korte, W., Allanore, Y., Denton, C. P. \& Matucci Cerinic, M. (2015). Coagulation factor XIII: a multifunctional transglutaminase with clinical potential in a range of conditions. Thromb Haemost 113, 686-97.

[125] Phillips, M., Dickneite, G. \& Metzner, H. (2003). Fibrin sealants in supporting surgical techniques: strength in factor XIII. Cardiovasc Surg 11 Suppl 1, 13-6.

[126] Standeven, K. F., Carter, A. M., Grant, P. J., Weisel, J. W., Chernysh, I., Masova, L., Lord, S. T. \& Ariëns, R. A. S. (2007). Functional analysis of fibrin \{gamma\}-chain cross-linking by activated factor XIII: determination of a cross-linking pattern that maximizes clot stiffness. Blood 110, 902-7.

[127] Richardson, V. R., Cordell, P., Standeven, K. F. \& Carter, A. M. (2013). Substrates of Factor XIII-A: roles in thrombosis and wound healing. Clin Sci (Lond) 124, 123-37.

[128] Zhmurov, A., Brown, A. E., Litvinov, R. I., Dima, R. I., Weisel, J. W. \& Barsegov, V. (2011). Mechanism of fibrin(ogen) forced unfolding. Structure 19, 1615-24.

[129] Zhmurov, A., Kononova, O., Litvinov, R. I., Dima, R. I., Barsegov, V. \& Weisel, J. W. (2012). Mechanical transition from alpha-helical coiled coils to beta-sheets in fibrin(ogen). $\mathrm{J} \mathrm{Am}$ Chem Soc 134, 20396-402.

[130] Weisel, J. W. (2005). Fibrinogen and fibrin. Adv Protein Chem 70, 247-99.

[131] Weisel, J. W. (2007). Structure of fibrin: impact on clot stability. J Thromb Haemost 5 Suppl 1, 116-24.

[132] Wolberg, A. S. (2007). Thrombin generation and fibrin clot structure. Blood Rev 21, 131-42.

[133] Cilia La Corte, A. L., Philippou, H. \& Ariëns, R. A. S. (2011). Role of fibrin structure in thrombosis and vascular disease. Adv Protein Chem Struct Biol 83, 75-127.

[134] Undas, A., Nowakowski, T., Cieśla-Dul, M. \& Sadowski, J. (2011). Abnormal plasma fibrin clot characteristics are associated with worse clinical outcome in patients with peripheral arterial disease and thromboangiitis obliterans. Atherosclerosis 215, 481-6.

[135] Wolberg, A. S. (2012). Determinants of fibrin formation, structure, and function. Curr Opin Hematol 19, 349-56.

[136] Undas, A. (2014). Fibrin clot properties and their modulation in thrombotic disorders. Thromb Haemost 112, 32-42.

[137] Undas, A., Szuldrzynski, K., Stepien, E., Zalewski, J., Godlewski, J., Tracz, W., Pasowicz, M. \& Zmudka, K. (2008). Reduced clot permeability and susceptibility to lysis in patients with acute coronary syndrome: effects of inflammation and oxidative stress. Atherosclerosis 196, 551-7.

[138] Chapin, J. W., Becker, G. L., Hulbert, B. J., Newland, M. C., Cuka, D. J., Wood, R. P. \& Shaw, B. W., Jr. (1989). Comparison of Thromboelastograph and Sonoclot coagulation 
bioRxiv preprint doi: https://doi.org/10.1101/054734; this version posted May 21, 2016. The copyright holder for this preprint (which was not certified by peer review) is the author/funder, who has granted bioRxiv a license to display the preprint in perpetuity. It is made available under aCC-BY 4.0 International license.

analyzer for assessing coagulation status during orthotopic liver transplantation. Transplant Proc 21, 3539.

[139] Longstaff, C. \& Kolev, K. (2015). Basic mechanisms and regulation of fibrinolysis. J Thromb Haemost 13 Suppl 1, S98-105.

[140] Ariëns, R. A. S. (2011). Elevated fibrinogen causes thrombosis. Blood 117, 4687-8.

[141] Ariëns, R. A. S. (2013). Fibrin(ogen) and thrombotic disease. J Thromb Haemost 11 Suppl 1, 294-305.

[142] Bridge, K. I., Philippou, H. \& Ariëns, R. A. S. (2014). Clot properties and cardiovascular disease. Thromb Haemost 112, 901-8.

[143] Bates, S. M. \& Weitz, J. I. (2005). Coagulation assays. Circulation 112, e53-60.

[144] Berntorp, E. \& Salvagno, G. L. (2008). Standardization and clinical utility of thrombingeneration assays. Semin Thromb Hemost 34, 670-82.

[145] Ganter, M. T. \& Hofer, C. K. (2008). Coagulation monitoring: Current techniques and clinical use of viscoelastic point-of-care coagulation devices. Anesthes Analges 106, 1366-1375.

[146] McMichael, M. A. \& Smith, S. A. (2011). Viscoelastic coagulation testing: technology, applications, and limitations. Veterinary clinical pathology / American Society for Veterinary Clinical Pathology 40, 140-53.

[147] Chitlur, M. (2012). Challenges in the laboratory analyses of bleeding disorders. Thromb Res 130, 1-6.

[148] Kell, D. B. \& Pretorius, E. (2015). The simultaneous occurrence of both hypercoagulability and hypofibrinolysis in blood and serum during systemic inflammation, and the roles of iron and fibrin(ogen). Integr Biol 7, 24-52.

[149] Johansson, P. I., Stissing, T., Bochsen, L. \& Ostrowski, S. R. (2009). Thrombelastography and tromboelastometry in assessing coagulopathy in trauma. Scand J Trauma Resusc Emerg Med 17, 45.

[150] Chee, Y. L. (2014). Coagulation. J R Coll Physicians Edinb 44, 42-5.

[151] Reikvam, H., Steien, E., Hauge, B., Liseth, K., Hagen, K. G., Storkson, R. \& Hervig, T. (2009). Thrombelastography. Transfus Apher Sci 40, 119-23.

[152] Afshari, A., Wikkelsø, A., Brok, J., Moller, A. M. \& Wetterslev, J. (2011). Thrombelastography (TEG) or thromboelastometry (ROTEM) to monitor haemotherapy versus usual care in patients with massive transfusion. Cochrane Database Syst Rev, CD007871.

[153] Bolliger, D., Seeberger, M. D. \& Tanaka, K. A. (2012). Principles and practice of thromboelastography in clinical coagulation management and transfusion practice. Transfus Med Rev 26, 1-13.

[154] Sankarankutty, A., Nascimento, B., Teodoro da Luz, L. \& Rizoli, S. (2012). TEG(R) and ROTEM(R) in trauma: similar test but different results? World J Emerg Surg 7 Suppl 1, S3.

[155] Sørensen, B. \& Ingerslev, J. (2005). Tailoring haemostatic treatment to patient requirements an update on monitoring haemostatic response using thrombelastography. Haemophilia 11 Suppl 1, 1-6.

[156] van Veen, J. J., Gatt, A., Bowyer, A. E., Cooper, P. C., Kitchen, S. \& Makris, M. (2009). Calibrated automated thrombin generation and modified thromboelastometry in haemophilia A. Thromb Res 123, 895-901.

[157] Kjellberg, U. \& Hellgren, M. (2000). Sonoclot signature during normal pregnancy. Intensive care medicine 26, 206-211.

[158] Hett, D. A., Walker, D., Pilkington, S. N. \& Smith, D. C. (1995). Sonoclot analysis. British journal of anaesthesia 75, 771-6.

[159] Sharma, S., Uprichard, J., Moretti, A., Boyce, H., Szydlo, R. \& Stocks, G. (2013). Use of thromboelastography to assess the combined role of pregnancy and obesity on coagulation: a prospective study. Int J Obstet Anesth 22, 113-118.

[160] Bester, J., Soma, P., Kell, D. B. \& Pretorius, E. (2015). Viscoelastic and ultrastructural characteristics of whole blood and plasma in Alzheimer-type dementia, and the possible role of bacterial lipopolysaccharides (LPS). Oncotarget Gerontology 6, 35284-35303.

[161] de Villiers, S., Swanepoel, A., Bester, J. \& Pretorius, E. (2016). Novel Diagnostic and Monitoring Tools in Stroke: an Individualized Patient-Centered Precision Medicine Approach. J Atheroscler Thromb 23, 493-504. 
bioRxiv preprint doi: https://doi.org/10.1101/054734; this version posted May 21, 2016. The copyright holder for this preprint (which was not certified by peer review) is the author/funder, who has granted bioRxiv a license to display the preprint in perpetuity. It is made available under aCC-BY 4.0 International license.

[162] Nielsen, V. G., Pretorius, E., Bester, J., Jacobsen, W. K., Boyle, P. K. \& Reinhard, J. P. (2015). Carbon Monoxide and Iron Modulate Plasmatic Coagulation in Alzheimer's Disease. Curr Neurovasc Res 12, 31-39.

[163] Nielsen, V. G. \& Pretorius, E. (2014). Iron and carbon monoxide enhance coagulation and attenuate fibrinolysis by different mechanisms. Blood Coagul Fibrinolysis 25, 695-702.

[164] Nielsen, V. G. \& Pretorius, E. (2014). Iron-enhanced coagulation is attenuated by chelation: thrombelastographic and ultrastructural analysis. Blood Coagul Fibrinolysis 25, 845-50.

[165] Swanepoel, A. C., Nielsen, V. G. \& Pretorius, E. (2015). Viscoelasticity and Ultrastructure in Coagulation and Inflammation: Two Diverse Techniques, One Conclusion. Inflammation 38, 1707-1726.

[166] Kell, D. B. \& Pretorius, E. (2015). On the translocation of bacteria and their lipopolysaccharides between blood and peripheral locations in chronic, inflammatory diseases: the central roles of LPS and LPS-induced cell death Integr Biol 7, 1339-1377.

[167] Potgieter, M., Bester, J., Kell, D. B. \& Pretorius, E. (2015). The dormant blood microbiome in chronic, inflammatory diseases. FEMS Microbiol Rev 39, 567-591.

[168] Pretorius, E., Bester, J., Vermeulen, N., Lipinski, B., Gericke, G. S. \& Kell, D. B. (2014). Profound morphological changes in the erythrocytes and fibrin networks of patients with hemochromatosis or with hyperferritinemia, and their normalization by iron chelators and other agents. PLoS One 9, e85271.

[169] Pretorius, E. \& Kell, D. B. (2014). Diagnostic morphology: biophysical indicators for irondriven inflammatory diseases. Integrative Biol 6, 486-510.

[170] Pretorius, E., Mbotwe, S., Bester, J., Robinson, C. \& Kell, D. B. (2016). Acute induction of anomalous blood clotting by highly substoichiometric levels of bacterial lipopolysaccharide (LPS). bioRXiv, 2016-053538v1.

[171] Pretorius, E., Vermeulen, N., Bester, J., Lipinski, B. \& Kell, D. B. (2013). A novel method for assessing the role of iron and its functional chelation in fibrin fibril formation: the use of scanning electron microscopy. Toxicol Mech Methods 23, 352-359.

[172] Pretorius, E., Olumuyiwa-Akeredolu, O. O., Mbotwe, S. \& Bester, J. (2016). Erythrocytes and their role as health indicator: Using structure in a patient-orientated precision medicine approach. Blood Rev.

[173] Bély, M. \& Makovitzky, J. (2006). Sensitivity and specificity of Congo red staining according to Romhányi. Comparison with Puchtler's or Bennhold's methods. Acta Histochem 108, 175-80.

[174] Frid, P., Anisimov, S. V. \& Popovic, N. (2007). Congo red and protein aggregation in neurodegenerative diseases. Brain Res Rev 53, 135-60.

[175] Howie, A. J., Brewer, D. B., Howell, D. \& Jones, A. P. (2008). Physical basis of colors seen in Congo red-stained amyloid in polarized light. Lab Invest 88, 232-42.

[176] Howie, A. J. \& Brewer, D. B. (2009). Optical properties of amyloid stained by Congo red: history and mechanisms. Micron 40, 285-301.

[177] Howie, A. J. \& Owen-Casey, M. P. (2010). Discrepancies between descriptions and illustrations of colours in Congo red-stained amyloid, and explanation of discrepant colours. Amyloid 17, 109-17.

[178] Inouye, H. \& Kirschner, D. A. (2005). Alzheimer's beta-amyloid: insights into fibril formation and structure from Congo red binding. Subcell Biochem 38, 203-24.

[179] Kelényi, G. (1967). Thioflavin S fluorescent and Congo red anisotropic stainings in the histologic demonstration of amyloid. Acta Neuropathol 7, 336-48.

[180] Maezawa, I., Hong, H. S., Liu, R., Wu, C. Y., Cheng, R. H., Kung, M. P., Kung, H. F., Lam, K. S., Oddo, S., Laferla, F. M. \& Jin, L. W. (2008). Congo red and thioflavin-T analogs detect Abeta oligomers. J Neurochem 104, 457-68.

[181] Wu, C., Scott, J. \& Shea, J. E. (2012). Binding of Congo red to amyloid protofibrils of the Alzheimer Abeta(9-40) peptide probed by molecular dynamics simulations. Biophysical journal 103, 550-7.

[182] Nilsson, M. R. (2004). Techniques to study amyloid fibril formation in vitro. Methods 34, 15160.

[183] Puchtler, H. \& Sweat, F. (1966). A review of early concepts of amyloid in context with contemporary chemical literature from 1839 to 1859. J Histochem Cytochem 14, 123-34.

[184] Steensma, D. P. (2001). "Congo" red: out of Africa? Arch Pathol Lab Med 125, 250-2. 
bioRxiv preprint doi: https://doi.org/10.1101/054734; this version posted May 21, 2016. The copyright holder for this preprint (which was not certified by peer review) is the author/funder, who has granted bioRxiv a license to display the preprint in perpetuity. It is made available under aCC-BY 4.0 International license.

[185] Bennhold, H. (1922). Eine spezifische Amyloidfärbung mit Kongorot Münch. Med. Woch. 69, 1537-1538.

[186] Howie, A. J. (2015). "Green (or apple-green) birefringence" of Congo red-stained amyloid. Amyloid 22, 205-6.

[187] Inouye, H., Nguyen, J. T., Fraser, P. E., Shinchuk, L. M., Packard, A. B. \& Kirschner, D. A. (2000). Histidine residues underlie Congo red binding to A beta analogs. Amyloid 7, 17988.

[188] Groenning, M. (2010). Binding mode of Thioflavin T and other molecular probes in the context of amyloid fibrils-current status. J Chem Biol 3, 1-18.

[189] Khurana, R., Coleman, C., Ionescu-Zanetti, C., Carter, S. A., Krishna, V., Grover, R. K., Roy, R. \& Singh, S. (2005). Mechanism of thioflavin T binding to amyloid fibrils. J Struct Biol 151, 229-38.

[190] Kuznetsova, I. M., Sulatskaya, A. I., Uversky, V. N. \& Turoverov, K. K. (2012). Analyzing thioflavin T binding to amyloid fibrils by an equilibrium microdialysis-based technique. PLoS One 7, e30724.

[191] Kuznetsova, I. M., Sulatskaya, A. I., Uversky, V. N. \& Turoverov, K. K. (2012). A new trend in the experimental methodology for the analysis of the thioflavin $\mathrm{T}$ binding to amyloid fibrils. Mol Neurobiol 45, 488-98.

[192] Kuznetsova, I. M., Sulatskaya, A. I., Maskevich, A. A., Uversky, V. N. \& Turoverov, K. K. (2016). High Fluorescence Anisotropy of Thioflavin T in Aqueous Solution Resulting from Its Molecular Rotor Nature. Anal Chem 88, 718-24.

[193] LeVine, H., 3rd. (1997). Stopped-flow kinetics reveal multiple phases of thioflavin T binding to Alzheimer beta (1-40) amyloid fibrils. Arch Biochem Biophys 342, 306-16.

[194] LeVine, H., 3rd. (1999). Quantification of beta-sheet amyloid fibril structures with thioflavin T. Methods Enzymol 309, 274-84.

[195] Lindberg, D. J., Wranne, M. S., Gilbert Gatty, M., Westerlund, F. \& Esbjörner, E. K. (2015). Steady-state and time-resolved Thioflavin-T fluorescence can report on morphological differences in amyloid fibrils formed by Abeta(1-40) and Abeta(1-42). Biochem Biophys Res Commun 458, 418-23.

[196] Naiki, H., Higuchi, K., Hosokawa, M. \& Takeda, T. (1989). Fluorometric determination of amyloid fibrils in vitro using the fluorescent dye, thioflavin T1. Anal Biochem 177, 244-9.

[197] Picken, M. M. \& Herrera, G. A. (2012). Thioflavin T Stain: An Easier and More Sensitive Method for Amyloid Detection. Curr Clin Pathol, 187-189.

[198] Robbins, K. J., Liu, G., Selmani, V. \& Lazo, N. D. (2012). Conformational analysis of thioflavin T bound to the surface of amyloid fibrils. Langmuir 28, 16490-5.

[199] Sulatskaya, A. I., Kuznetsova, I. M. \& Turoverov, K. K. (2011). Interaction of thioflavin T with amyloid fibrils: stoichiometry and affinity of dye binding, absorption spectra of bound dye. $J$ Phys Chem B 115, 11519-24.

[200] Sulatskaya, A. I., Kuznetsova, I. M. \& Turoverov, K. K. (2012). Interaction of thioflavin T with amyloid fibrils: fluorescence quantum yield of bound dye. J Phys Chem B 116, 2538-44.

[201] Wolfe, L. S., Calabrese, M. F., Nath, A., Blaho, D. V., Miranker, A. D. \& Xiong, Y. (2010). Protein-induced photophysical changes to the amyloid indicator dye thioflavin T. Proc Natl Acad Sci U S A 107, 16863-8.

[202] Palhano, F. L., Lee, J., Grimster, N. P. \& Kelly, J. W. (2013). Toward the molecular mechanism(s) by which EGCG treatment remodels mature amyloid fibrils. J Am Chem Soc 135, 7503-10.

[203] Younan, N. D. \& Viles, J. H. (2015). A Comparison of Three Fluorophores for the Detection of Amyloid Fibers and Prefibrillar Oligomeric Assemblies. ThT (Thioflavin T); ANS (1Anilinonaphthalene-8-sulfonic Acid); and bisANS (4,4'-Dianilino-1,1'-binaphthyl-5,5'disulfonic Acid). Biochemistry 54, 4297-306.

[204] Zhang, X. \& Ran, C. (2013). Dual Functional Small Molecule Probes as Fluorophore and Ligand for Misfolding Proteins. Curr Org Chem 17.

[205] Ban, T., Hamada, D., Hasegawa, K., Naiki, H. \& Goto, Y. (2003). Direct observation of amyloid fibril growth monitored by thioflavin T fluorescence. J Biol Chem 278, 16462-5.

[206] Berthoumieu, O., Nguyen, P. H., Castillo-Frias, M. P., Ferre, S., Tarus, B., Nasica-Labouze, J., Noel, S., Saurel, O., Rampon, C., Doig, A. J., Derreumaux, P. \& Faller, P. (2015). 
bioRxiv preprint doi: https://doi.org/10.1101/054734; this version posted May 21, 2016. The copyright holder for this preprint (which was not certified by peer review) is the author/funder, who has granted bioRxiv a license to display the preprint in perpetuity. It is made available under aCC-BY 4.0 International license.

Combined experimental and simulation studies suggest a revised mode of action of the anti-Alzheimer disease drug NQ-Trp. Chemistry 21, 12657-66.

[207] Biancalana, M., Makabe, K., Koide, A. \& Koide, S. (2009). Molecular mechanism of thioflavinT binding to the surface of beta-rich peptide self-assemblies. $J$ Mol Biol 385, 1052-63.

[208] Di Carlo, M. G., Minicozzi, V., Fodera, V., Militello, V., Vetri, V., Morante, S. \& Leone, M. (2015). Thioflavin T templates amyloid beta(1-40) conformation and aggregation pathway. Biophys Chem 206, 1-11.

[209] Groenning, M., Olsen, L., van de Weert, M., Flink, J. M., Frokjaer, S. \& Jorgensen, F. S. (2007). Study on the binding of Thioflavin T to beta-sheet-rich and non-beta-sheet cavities. J Struct Biol 158, 358-69.

[210] Jha, S., Patil, S. M., Gibson, J., Nelson, C. E., Alder, N. N. \& Alexandrescu, A. T. (2011). Mechanism of Amylin Fibrillization Enhancement by Heparin. J Biol Chem 286, 2289422904.

[211] Jha, S., Snell, J. M., Sheftic, S. R., Patil, S. M., Daniels, S. B., Kolling, F. W. \& Alexandrescu, A. T. (2014). pH Dependence of Amylin Fibrillization. Biochemistry 53, 300-310.

[212] LeVine, H., 3rd. (1993). Thioflavine T interaction with synthetic Alzheimer's disease betaamyloid peptides: detection of amyloid aggregation in solution. Protein Sci 2, 404-10.

[213] Ozawa, D., Kaji, Y., Yagi, H., Sakurai, K., Kawakami, T., Naiki, H. \& Goto, Y. (2011). Destruction of amyloid fibrils of keratoepithelin peptides by laser irradiation coupled with amyloid-specific thioflavin T. J Biol Chem 286, 10856-63.

[214] Sabaté, R. \& Ventura, S. (2013). Cross-beta-sheet supersecondary structure in amyloid folds: techniques for detection and characterization. Methods Mol Biol 932, 237-57.

[215] Wu, C., Wei, J., Gao, K. \& Wang, Y. (2007). Dibenzothiazoles as novel amyloid-imaging agents. Bioorg Med Chem 15, 2789-96.

[216] Sun, A., Nguyen, X. V. \& Bing, G. (2002). Comparative analysis of an improved thioflavin-S stain, Gallyas silver stain, and immunohistochemistry for neurofibrillary tangle demonstration on the same sections. J Histochem Cytochem 50, 463-72.

[217] Dobson, P. D. \& Kell, D. B. (2008). Carrier-mediated cellular uptake of pharmaceutical drugs: an exception or the rule? Nat Rev Drug Disc 7, 205-220.

[218] Kell, D. B., Dobson, P. D. \& Oliver, S. G. (2011). Pharmaceutical drug transport: the issues and the implications that it is essentially carrier-mediated only. Drug Disc Today 16, 704714.

[219] Kell, D. B., Dobson, P. D., Bilsland, E. \& Oliver, S. G. (2013). The promiscuous binding of pharmaceutical drugs and their transporter-mediated uptake into cells: what we (need to) know and how we can do so. Drug Disc Today 18, 218-239.

[220] Kell, D. B. \& Oliver, S. G. (2014). How drugs get into cells: tested and testable predictions to help discriminate between transporter-mediated uptake and lipoidal bilayer diffusion. Front Pharmacol 5, 231.

[221] Mathis, C. A., Wang, Y., Holt, D. P., Huang, G. F., Debnath, M. L. \& Klunk, W. E. (2003). Synthesis and evaluation of ${ }^{11} \mathrm{C}$-labeled 6-substituted 2-arylbenzothiazoles as amyloid imaging agents. J Med Chem 46, 2740-54.

[222] Wu, C., Bowers, M. T. \& Shea, J. E. (2011). On the origin of the stronger binding of PIB over thioflavin $T$ to protofibrils of the Alzheimer amyloid-beta peptide: a molecular dynamics study. Biophys J 100, 1316-24.

[223] Murray, M. E., Lowe, V. J., Graff-Radford, N. R., Liesinger, A. M., Cannon, A., Przybelski, S. A., Rawal, B., Parisi, J. E., Petersen, R. C., Kantarci, K., Ross, O. A., Duara, R., Knopman, D. S., Jack, C. R., Jr. \& Dickson, D. W. (2015). Clinicopathologic and ${ }^{11}$ C-Pittsburgh compound B implications of Thal amyloid phase across the Alzheimer's disease spectrum. Brain.

[224] O'Hagan, S., Swainston, N., Handl, J. \& Kell, D. B. (2015). A 'rule of 0.5' for the metabolite-likeness of approved pharmaceutical drugs. Metabolomics 11, 323-339.

[225] O'Hagan, S. \& Kell, D. B. (2015). Understanding the foundations of the structural similarities between marketed drugs and endogenous human metabolites. Front Pharmacol 6, 105.

[226] Thiele, I. G., Niezen-Koning, K. E., van Gennip, A. H. \& Aarnoudse, J. G. (2004). Increased plasma carnitine concentrations in preeclampsia. Obstet Gynecol 103, 876-80.

[227] Swainston, N., Mendes, P. \& Kell, D. B. (2013). An analysis of a 'community-driven' reconstruction of the human metabolic network. Metabolomics 9, 757-764. 
bioRxiv preprint doi: https://doi.org/10.1101/054734; this version posted May 21, 2016. The copyright holder for this preprint (which was not certified by peer review) is the author/funder, who has granted bioRxiv a license to display the preprint in perpetuity. It is made available under aCC-BY 4.0 International license.

[228] Swainston, N., Smallbone, K., Hefzi, H., Dobson, P. D., Brewer, J., Hanscho, M., Zielinski, D. C., Ang, K. S., Gardiner, N. J., Gutierrez, J. M., Kyriakopoulos, S., Lakshmanan, M., Li, S., Liu, J. K., Martínez, V. S., Orellana, C. A., Quek, L.-E., Thomas, A., Zanghellini, J., Borth, N., Lee, D.-Y., Nielsen, L. K., Kell, D. B., Lewis, N. E. \& Mendes, P. (2016). Recon 2.2: from reconstruction to model of human metabolism. Metabolomics, in press.

[229] Mathis, C. A., Lopresti, B. J. \& Klunk, W. E. (2007). Impact of amyloid imaging on drug development in Alzheimer's disease. Nucl Med Biol 34, 809-22.

[230] Grimmer, T., Henriksen, G., Wester, H. J., Förstl, H., Klunk, W. E., Mathis, C. A., Kurz, A. \& Drzezga, A. (2009). Clinical severity of Alzheimer's disease is associated with PIB uptake in PET. Neurobiol Aging 30, 1902-9.

[231] Resnick, S. M., Sojkova, J., Zhou, Y., An, Y., Ye, W., Holt, D. P., Dannals, R. F., Mathis, C. A., Klunk, W. E., Ferrucci, L., Kraut, M. A. \& Wong, D. F. (2010). Longitudinal cognitive decline is associated with fibrillar amyloid-beta measured by [11C]PiB. Neurology 74, 80715.

[232] Driscoll, I., Troncoso, J. C., Rudow, G., Sojkova, J., Pletnikova, O., Zhou, Y., Kraut, M. A., Ferrucci, L., Mathis, C. A., Klunk, W. E., O'Brien, R. J., Davatzikos, C., Wong, D. F. \& Resnick, S. M. (2012). Correspondence between in vivo (11)C-PiB-PET amyloid imaging and postmortem, region-matched assessment of plaques. Acta Neuropathol 124, 823-31.

[233] Durant, J. L., Leland, B. A., Henry, D. R. \& Nourse, J. G. (2002). Reoptimization of MDL keys for use in drug discovery. J Chem Inf Comput Sci 42, 1273-80.

[234] Styren, S. D., Hamilton, R. L., Styren, G. C. \& Klunk, W. E. (2000). X-34, a fluorescent derivative of Congo red: a novel histochemical stain for Alzheimer's disease pathology. $J$ Histochem Cytochem 48, 1223-32.

[235] Link, C. D., Johnson, C. J., Fonte, V., Paupard, M., Hall, D. H., Styren, S., Mathis, C. A. \& Klunk, W. E. (2001). Visualization of fibrillar amyloid deposits in living, transgenic Caenorhabditis elegans animals using the sensitive amyloid dye, X-34. Neurobiol Aging 22, 217-26.

[236] Ikonomovic, M. D., Abrahamson, E. E., Isanski, B. A., Debnath, M. L., Mathis, C. A., Dekosky, S. T. \& Klunk, W. E. (2006). X-34 labeling of abnormal protein aggregates during the progression of Alzheimer's disease. Methods Enzymol 412, 123-44.

[237] Klunk, W. E., Debnath, M. L. \& Pettegrew, J. W. (1994). Development of small molecule probes for the beta-amyloid protein of Alzheimer's disease. Neurobiol Aging 15, 691-8.

[238] Kang, J. \& Han, K. (2001). The amide derivatives of chrysamine $\mathrm{G}$ bind to the beta-amyloid fibril. Bulletin of the Korean Chemical Society 22, 1065-1066.

[239] Stefansson, S., Adams, D. L. \& Tang, C. M. (2012). Common benzothiazole and benzoxazole fluorescent DNA intercalators for studying Alzheimer Abeta1-42 and prion amyloid peptides. Biotechniques 52.

[240] Lindberg, D. J. \& Esbjorner, E. K. (2016). Detection of amyloid-beta fibrils using the DNAintercalating dye YOYO-1: Binding mode and fibril formation kinetics. Biochem Biophys Res Commun 469, 313-8.

[241] Reuter, M. \& Dryden, D. T. F. (2010). The kinetics of YOYO-1 intercalation into single molecules of double-stranded DNA. Biochem Biophys Res Commun 403, 225-229.

[242] Twist, C. R., Winson, M. K., Rowland, J. J. \& Kell, D. B. (2004). SNP detection using nanomolar nucleotides and single molecule fluorescence. Anal. Biochem. 327, 35-44.

[243] Chernysh, I. N., Nagaswami, C., Purohit, P. K. \& Weisel, J. W. (2012). Fibrin clots are equilibrium polymers that can be remodeled without proteolytic digestion. Sci Rep 2, 879.

[244] Averett, L. E., Geer, C. B., Fuierer, R. R., Akhremitchev, B. B., Gorkun, O. V. \& Schoenfisch, M. H. (2008). Complexity of "A-a" knob-hole fibrin interaction revealed by atomic force spectroscopy. Langmuir 24, 4979-88.

[245] Averett, L. E., Schoenfisch, M. H., Akhremitchev, B. B. \& Gorkun, O. V. (2009). Kinetics of the multistep rupture of fibrin 'A-a' polymerization interactions measured using atomic force microscopy. Biophys J 97, 2820-8.

[246] Yermolenko, I. S., Lishko, V. K., Ugarova, T. P. \& Magonov, S. N. (2011). High-resolution visualization of fibrinogen molecules and fibrin fibers with atomic force microscopy. Biomacromolecules 12, 370-9. 
bioRxiv preprint doi: https://doi.org/10.1101/054734; this version posted May 21, 2016. The copyright holder for this preprint (which was not certified by peer review) is the author/funder, who has granted bioRxiv a license to display the preprint in perpetuity. It is made available under aCC-BY 4.0 International license.

[247] Protopopova, A. D., Barinov, N. A., Zavyalova, E. G., Kopylov, A. M., Sergienko, V. I. \& Klinov, D. V. (2015). Visualization of fibrinogen alphaC regions and their arrangement during fibrin network formation by high-resolution AFM. J Thromb Haemost 13, 570-9.

[248] Benson, M. D., Liepnieks, J., Uemichi, T., Wheeler, G. \& Correa, R. (1993). Hereditary renal amyloidosis associated with a mutant fibrinogen alpha-chain. Nat Genet 3, 252-5.

[249] Hamidi Asl, L., Liepnieks, J. J., Uemichi, T., Rebibou, J. M., Justrabo, E., Droz, D., Mousson, C., Chalopin, J. M., Benson, M. D., Delpech, M. \& Grateau, G. (1997). Renal amyloidosis with a frame shift mutation in fibrinogen aalpha-chain gene producing a novel amyloid protein. Blood 90, 4799-805.

[250] Serpell, L. C., Benson, M., Liepnieks, J. J. \& Fraser, P. E. (2007). Structural analyses of fibrinogen amyloid fibrils. Amyloid 14, 199-203.

[251] Gillmore, J. D., Lachmann, H. J., Rowczenio, D., Gilbertson, J. A., Zeng, C. H., Liu, Z. H., Li, L. S., Wechalekar, A. \& Hawkins, P. N. (2009). Diagnosis, pathogenesis, treatment, and prognosis of hereditary fibrinogen A alpha-chain amyloidosis. J Am Soc Nephrol 20, 44451.

[252] Picken, M. M. (2010). Fibrinogen amyloidosis: the clot thickens! Blood 115, 2985-6.

[253] Stangou, A. J., Banner, N. R., Hendry, B. M., Rela, M., Portmann, B., Wendon, J., Monaghan, M., Maccarthy, P., Buxton-Thomas, M., Mathias, C. J., Liepnieks, J. J., O'Grady, J., Heaton, N. D. \& Benson, M. D. (2010). Hereditary fibrinogen A alpha-chain amyloidosis: phenotypic characterization of a systemic disease and the role of liver transplantation. Blood 115, 2998-3007.

[254] Haidinger, M., Werzowa, J., Kain, R., Antlanger, M., Hecking, M., Pfaffenberger, S., Mascherbauer, J., Gremmel, T., Gilbertson, J. A., Rowczenio, D., Weichhart, T., Kopecky, C., Hörl, W. H., Hawkins, P. N. \& Säemann, M. D. (2013). Hereditary amyloidosis caused by R554L fibrinogen Aalpha-chain mutation in a Spanish family and review of the literature. Amyloid 20, 72-9.

[255] Bramanti, E., Benedetti, E., Sagripanti, A., Papineschi, F. \& Benedetti, E. (1997). Determination of secondary structure of normal fibrin from human peripheral blood. Biopolymers 41, 545-53.

[256] Kreplak, L., Doucet, J., Dumas, P. \& Briki, F. (2004). New aspects of the alpha-helix to betasheet transition in stretched hard alpha-keratin fibers. Biophys $\mathrm{J}$ 87, 640-7.

[257] Liu, W., Carlisle, C. R., Sparks, E. A. \& Guthold, M. (2010). The mechanical properties of single fibrin fibers. J Thromb Haemost 8, 1030-6.

[258] Miserez, A. \& Guerette, P. A. (2013). Phase transition-induced elasticity of alpha-helical bioelastomeric fibres and networks. Chem Soc Rev 42, 1973-95.

[259] Münster, S., Jawerth, L. M., Fabry, B. \& Weitz, D. A. (2013). Structure and mechanics of fibrin clots formed under mechanical perturbation. J Thromb Haemost 11, 557-60.

[260] Kim, O. V., Litvinov, R. I., Weisel, J. W. \& Alber, M. S. (2014). Structural basis for the nonlinear mechanics of fibrin networks under compression. Biomaterials 35, 6739-49.

[261] Tao, W., Yoon, G., Cao, P., Eom, K. \& Park, H. S. (2015). beta-sheet-like formation during the mechanical unfolding of prion protein. J Chem Phys 143, 125101.

[262] Hearle, J. W. S. (2000). A critical review of the structural mechanics of wool and hair fibres. Int J Biol Macromol 27, 123-38.

[263] Feughelman, M. (2002). Natural protein fibers. J Appl Polymer Sci 83, 489-507.

[264] Qin, Z. \& Buehler, M. J. (2010). Molecular dynamics simulation of the alpha-helix to betasheet transition in coiled protein filaments: evidence for a critical filament length scale. Phys Rev Lett 104, 198304.

[265] Bendit, E. G. (1957). The alpha-beta transformation in keratin. Nature 179, 535.

[266] Bendit, E. G. (1960). A Quantitative X-Ray Diffraction Study of the Alpha-Beta Transformation in Wool Keratin. Textile Res $\mathrm{J}$ 30, 547-555.

[267] Paquin, R. \& Colomban, P. (2007). Nanomechanics of single keratin fibres: A Raman study of the alpha-helix ->beta-sheet transition and the effect of water. J Raman Spectrosc 38, 504-514.

[268] Varjú, I., Sótonyi, P., Machovich, R., Szabó, L., Tenekedjiev, K., Silva, M. M. C. G., Longstaff, C. \& Kolev, K. (2011). Hindered dissolution of fibrin formed under mechanical stress. J Thromb Haemost 9, 979-86. 
bioRxiv preprint doi: https://doi.org/10.1101/054734; this version posted May 21, 2016. The copyright holder for this preprint (which was not certified by peer review) is the author/funder, who has granted bioRxiv a license to display the preprint in perpetuity. It is made available under aCC-BY 4.0 International license.

[269] Badiei, N., Sowedan, A. M., Curtis, D. J., Brown, M. R., Lawrence, M. J., Campbell, A. I., Sabra, A., Evans, P. A., Weisel, J. W., Chernysh, I. N., Nagaswami, C., Williams, P. R. \& Hawkins, K. (2015). Effects of unidirectional flow shear stresses on the formation, fractal microstructure and rigidity of incipient whole blood clots and fibrin gels. Clin Hemorheol Microcirc 60, 451-64.

[270] Campbell, R. A., Aleman, M., Gray, L. D., Falvo, M. R. \& Wolberg, A. S. (2010). Flow profoundly influences fibrin network structure: implications for fibrin formation and clot stability in haemostasis. Thromb Haemost 104, 1281-4.

[271] Lipinski, B., Pretorius, E., Oberholzer, H. M. \& Van Der Spuy, W. J. (2012). Iron enhances generation of fibrin fibers in human blood: Implications for pathogenesis of stroke. Microsc Res Tech 75, 1185-1190.

[272] Lipinski, B. \& Pretorius, E. (2013). Iron-induced fibrin in cardiovascular disease. Curr neurovasc res 10, 269-274.

[273] Lipinski, B. \& Pretorius, E. (2013). The Role of Iron-Induced Fibrin in the Pathogenesis of Alzheimer's Disease and the Protective Role of Magnesium. Front Hum Neurosci 7, 735.

[274] Pretorius, E. \& Oberholzer, H. M. (2009). Ultrastructural changes of platelets and fibrin networks in human asthma: a qualitative case study. Blood Coag Fibrinol 20, 146-9.

[275] Pretorius, E., Windberger, U. B., Oberholzer, H. M. \& Auer, R. E. (2010). Comparative ultrastructure of fibrin networks of a dog after thrombotic ischaemic stroke. Onderstepoort $\mathrm{J}$ Vet Res 77, E1-4.

[276] Pretorius, E., Oberholzer, H. M., van der Spuy, W. J. \& Meiring, J. H. (2010). The changed ultrastructure of fibrin networks during use of oral contraception and hormone replacement. J Thromb Thrombolysis 30, 502-6.

[277] Pretorius, E. (2011). The use of a desktop scanning electron microscope as a diagnostic tool in studying fibrin networks of thrombo-embolic ischemic stroke. Ultrastruct Pathol 35, 24550 .

[278] Pretorius, E., Oberholzer, H. M., van der Spuy, W. J., Swanepoel, A. C. \& Soma, P. (2011). Qualitative scanning electron microscopy analysis of fibrin networks and platelet abnormalities in diabetes. Blood Coagul Fibrinol 22, 463-7.

[279] Pretorius, E., Olivier, J., Oberholzer, H. M. \& Van der Spuy, W. J. (2011). Scanning electron microscopy investigation of fibrin networks after thermal injury. Onderstepoort $\mathrm{J}$ Vet Res 78, 244.

[280] Pretorius, E. \& Lipinski, B. (2013). Differences in morphology of fibrin clots induced with thrombin and ferric ions and its pathophysiological consequences. Heart Lung Circ 22, 447449.

[281] Pretorius, E., Steyn, H., Engelbrecht, M., Swanepoel, A. C. \& Oberholzer, H. M. (2011). Differences in fibrin fiber diameters in healthy individuals and thromboembolic ischemic stroke patients. Blood Coagul Fibrinolysis 22, 696-700.

[282] Weigandt, K. M., White, N., Chung, D., Ellingson, E., Wang, Y., Fu, X. Y. \& Pozzo, D. C. (2012). Fibrin Clot Structure and Mechanics Associated with Specific Oxidation of Methionine Residues in Fibrinogen. Biophysical journal 103, 2399-2407.

[283] Bucay, I., O'Brien, E. T., 3rd, Wulfe, S. D., Superfine, R., Wolberg, A. S., Falvo, M. R. \& Hudson, N. E. (2015). Physical determinants of fibrinolysis in single fibrin fibers. PLoS One 10, e0116350.

[284] Draxler, D. F. \& Medcalf, R. L. (2015). The fibrinolytic system-more than fibrinolysis? Transfus Med Rev 29, 102-9.

[285] Walker, J. B. \& Nesheim, M. E. (1999). The molecular weights, mass distribution, chain composition, and structure of soluble fibrin degradation products released from a fibrin clot perfused with plasmin. J Biol Chem 274, 5201-12.

[286] Adam, S. S., Key, N. S. \& Greenberg, C. S. (2009). D-dimer antigen: current concepts and future prospects. Blood 113, 2878-87.

[287] Suga, N., Miura, N., Kitagawa, W., Morita, H., Banno, S. \& Imai, H. (2012). Differential diagnosis of localized and systemic amyloidosis based on coagulation and fibrinolysis parameters. Amyloid 19, 61-5.

[288] Medved, L. \& Nieuwenhuizen, W. (2003). Molecular mechanisms of initiation of fibrinolysis by fibrin. Thromb Haemost 89, 409-19. 
bioRxiv preprint doi: https://doi.org/10.1101/054734; this version posted May 21, 2016. The copyright holder for this preprint (which was not certified by peer review) is the author/funder, who has granted bioRxiv a license to display the preprint in perpetuity. It is made available under aCC-BY 4.0 International license.

[289] Nieuwenhuizen, W. (2001). Fibrin-mediated plasminogen activation. Ann N Y Acad Sci 936, 237-46.

[290] Collet, J. P., Lesty, C., Montalescot, G. \& Weisel, J. W. (2003). Dynamic changes of fibrin architecture during fibrin formation and intrinsic fibrinolysis of fibrin-rich clots. $J$ Biol Chem 278, 21331-5.

[291] Veklich, Y., Francis, C. W., White, J. \& Weisel, J. W. (1998). Structural studies of fibrinolysis by electron microscopy. Blood 92, 4721-9.

[292] Weisel, J. W. \& Litvinov, R. I. (2008). The biochemical and physical process of fibrinolysis and effects of clot structure and stability on the lysis rate. Cardiovasc Hematol Agents Med Chem 6, 161-80.

[293] Collet, J. P., Park, D., Lesty, C., Soria, J., Soria, C., Montalescot, G. \& Weisel, J. W. (2000). Influence of fibrin network conformation and fibrin fiber diameter on fibrinolysis speed: dynamic and structural approaches by confocal microscopy. Arterioscler Thromb Vasc Biol 20, 1354-61.

[294] Asakura, H. (2014). Classifying types of disseminated intravascular coagulation: clinical and animal models. J Intensive Care 2, 20.

[295] Bick, R. L. (2002). Disseminated intravascular coagulation: a review of etiology, pathophysiology, diagnosis, and management: guidelines for care. Clin Appl Thromb Hemost 8, 1-31.

[296] Kaneko, T. \& Wada, H. (2011). Diagnostic criteria and laboratory tests for disseminated intravascular coagulation. J Clin Exp Hematop 51, 67-76.

[297] Levi, M. \& van der Poll, T. (2013). Disseminated intravascular coagulation: a review for the internist. Int Emerg Med 8, 23-32.

[298] Wada, H., Matsumoto, T., Yamashita, Y. \& Hatada, T. (2014). Disseminated intravascular coagulation: testing and diagnosis. Clin Chim Acta 436, 130-4.

[299] Duburcq, T., Tournoys, A., Gnemmi, V., Hubert, T., Gmyr, V., Pattou, F. \& Jourdain, M. (2015). Impact of Obesity on Endotoxin-Induced Disseminated Intravascular Coagulation. Shock 44, 341-7.

[300] Wu, L. C., Lin, X. \& Sun, H. (2012). Tanshinone IIA protects rabbits against LPS-induced disseminated intravascular coagulation (DIC). Acta Pharmacol Sin 33, 1254-9.

[301] Wu, Z., Li, J. N., Bai, Z. Q. \& Lin, X. (2014). Antagonism by salvianolic acid B of lipopolysaccharide-induced disseminated intravascular coagulation in rabbits. Clin Exp Pharmacol Physiol 41, 502-8.

[302] Yu, P. X., Zhou, Q. J., Zhu, W. W., Wu, Y. H., Wu, L. C., Lin, X., Chen, M. H. \& Qiu, B. T. (2013). Effects of quercetin on LPS-induced disseminated intravascular coagulation (DIC) in rabbits. Thromb Res 131, e270-3.

[303] Gando, S. (2010). Microvascular thrombosis and multiple organ dysfunction syndrome. Crit Care Med 38, S35-S42.

[304] Cines, D. B., Lebedeva, T., Nagaswami, C., Hayes, V., Massefski, W., Litvinov, R. I., Rauova, L., Lowery, T. J. \& Weisel, J. W. (2014). Clot contraction: compression of erythrocytes into tightly packed polyhedra and redistribution of platelets and fibrin. Blood 123, 1596-603.

[305] Kasahara, K., Souri, M., Kaneda, M., Miki, T., Yamamoto, N. \& Ichinose, A. (2010). Impaired clot retraction in factor XIII A subunit-deficient mice. Blood 115, 1277-9.

[306] Kasahara, K., Kaneda, M., Miki, T., lida, K., Sekino-Suzuki, N., Kawashima, I., Suzuki, H., Shimonaka, M., Arai, M., Ohno-Iwashita, Y., Kojima, S., Abe, M., Kobayashi, T., Okazaki, T., Souri, M., Ichinose, A. \& Yamamoto, N. (2013). Clot retraction is mediated by factor XIIIdependent fibrin-alphallbbeta3-myosin axis in platelet sphingomyelin-rich membrane rafts. Blood 122, 3340-8.

[307] Hethershaw, E. L., La Corte, A. L. C., Duval, C., Ali, M., Grant, P. J., Ariëns, R. A. S. \& Philippou, H. (2014). The effect of blood coagulation factor XIII on fibrin clot structure and fibrinolysis. J Thromb Haemost 12, 197-205.

[308] Sabovic, M., Lijnen, H. R., Keber, D. \& Collen, D. (1989). Effect of retraction on the lysis of human clots with fibrin specific and non-fibrin specific plasminogen activators. Thromb Haemost 62, 1083-7. 
bioRxiv preprint doi: https://doi.org/10.1101/054734; this version posted May 21, 2016. The copyright holder for this preprint (which was not certified by peer review) is the author/funder, who has granted bioRxiv a license to display the preprint in perpetuity. It is made available under aCC-BY 4.0 International license.

[309] Kunitada, S., FitzGerald, G. A. \& Fitzgerald, D. J. (1992). Inhibition of clot lysis and decreased binding of tissue-type plasminogen activator as a consequence of clot retraction. Blood 79, 1420-7.

[310] Šabovič, M. \& Blinc, A. (2000). Biochemical and biophysical conditions for blood clot lysis. Pflugers Arch 440, R134-6.

[311] Lackner, H., Hunt, V., Zucker, M. B. \& Pearson, J. (1970). Abnormal fibrin ultrastructure, polymerization, and clot retraction in multiple myeloma. $\mathrm{Br} J$ Haematol 18, 625-36.

[312] Carr, M. E., Jr. \& Zekert, S. L. (1994). Abnormal clot retraction, altered fibrin structure, and normal platelet function in multiple myeloma. Am J Physiol 266, H1195-201.

[313] Ahn, H. J., Zamolodchikov, D., Cortes-Canteli, M., Norris, E. H., Glickman, J. F. \& Strickland, S. (2010). Alzheimer's disease peptide beta-amyloid interacts with fibrinogen and induces its oligomerization. Proc Natl Acad Sci 107, 21812-21817.

[314] Ahn, H. J., Glickman, J. F., Poon, K. L., Zamolodchikov, D., Jno-Charles, O. C., Norris, E. H. \& Strickland, S. (2014). A novel Abeta-fibrinogen interaction inhibitor rescues altered thrombosis and cognitive decline in Alzheimer's disease mice. J Exp Med 211, 1049-62.

[315] Cortes-Canteli, M. \& Strickland, S. (2009). Fibrinogen, a possible key player in Alzheimer's disease. J Thromb Haemost 7, 146-150.

[316] Cortes-Canteli, M., Paul, J., Norris, E. H., Bronstein, R., Ahn, H. J., Zamolodchikov, D., Bhuvanendran, S., Fenz, K. M. \& Strickland, S. (2010). Fibrinogen and beta-amyloid association alters thrombosis and fibrinolysis: a possible contributing factor to Alzheimer's disease. Neuron 66, 695-709.

[317] Cortes-Canteli, M., Zamolodchikov, D., Ahn, H. J., Strickland, S. \& Norris, E. H. (2012). Fibrinogen and Altered Hemostasis in Alzheimer's Disease. J Alzheimers Dis 32, 599-608.

[318] Cortes-Canteli, M., Mattei, L., Richards, A. T., Norris, E. H. \& Strickland, S. (2015). Fibrin deposited in the Alzheimer's disease brain promotes neuronal degeneration. Neurobiol Aging 36, 608-17.

[319] Paul, J., Strickland, S. \& Melchor, J. P. (2007). Fibrin deposition accelerates neurovascular damage and neuroinflammation in mouse models of Alzheimer's disease. J Exp Med 204, 1999-2008.

[320] Zamolodchikov, D. \& Strickland, S. (2012). Abeta delays fibrin clot lysis by altering fibrin structure and attenuating plasminogen binding to fibrin. Blood 119, 3342-51.

[321] Fiala, M., Liu, Q. N., Sayre, J., Pop, V., Brahmandam, V., Graves, M. C. \& Vinters, H. V. (2002). Cyclooxygenase-2-positive macrophages infiltrate the Alzheimer's disease brain and damage the blood-brain barrier. Eur J Clin Invest 32, 360-71.

[322] Hardy, J. A. \& Higgins, G. A. (1992). Alzheimer's disease: the amyloid cascade hypothesis. Science 256, 184-5.

[323] Hardy, J. \& Selkoe, D. J. (2002). The amyloid hypothesis of Alzheimer's disease: progress and problems on the road to therapeutics. Science 297, 353-6.

[324] Jonsson, T., Atwal, J. K., Steinberg, S., Snaedal, J., Jonsson, P. V., Bjornsson, S., Stefansson, H., Sulem, P., Gudbjartsson, D., Maloney, J., Hoyte, K., Gustafson, A., Liu, Y., Lu, Y., Bhangale, T., Graham, R. R., Huttenlocher, J., Bjornsdottir, G., Andreassen, O. A., Jonsson, E. G., Palotie, A., Behrens, T. W., Magnusson, O. T., Kong, A., Thorsteinsdottir, U., Watts, R. J. \& Stefansson, K. (2012). A mutation in APP protects against Alzheimer's disease and age-related cognitive decline. Nature 488, 96-9.

[325] Minter, M. R., Taylor, J. M. \& Crack, P. J. (2016). The contribution of neuroinflammation to amyloid toxicity in Alzheimer's disease. $J$ Neurochem 136, 457-74.

[326] Selkoe, D. J. \& Hardy, J. (2016). The amyloid hypothesis of Alzheimer's disease at 25 years. EMBO Mol Med.

[327] Hardy, J. (2009). The amyloid hypothesis for Alzheimer's disease: a critical reappraisal. J Neurochem 110, 1129-34.

[328] Karran, E., Mercken, M. \& De Strooper, B. (2011). The amyloid cascade hypothesis for Alzheimer's disease: an appraisal for the development of therapeutics. Nat Rev Drug Discov 10, 698-712.

[329] Karran, E. \& Hardy, J. (2014). A critique of the drug discovery and phase 3 clinical programs targeting the amyloid hypothesis for Alzheimer disease. Ann Neurol 76, 185-205.

[330] Herrup, K. (2015). The case for rejecting the amyloid cascade hypothesis. Nat Neurosci 18, 794-9. 
bioRxiv preprint doi: https://doi.org/10.1101/054734; this version posted May 21, 2016. The copyright holder for this preprint (which was not certified by peer review) is the author/funder, who has granted bioRxiv a license to display the preprint in perpetuity. It is made available under aCC-BY 4.0 International license.

[331] Itzhaki, R. F., Lathe, R., Balin, B. J., Ball, M. J., Braak, H., Bearer, E. L., Bullido, M. J., Carter, C., Clerici, M., Cosby, S. L., Del Tredici, K., Field, H., Fulop, T., Grassi, C., Griffin, W. S. T., Haas, J., Hudson, A. P., Kamer, A., Kell, D. B., Licastro, F., Letenneur, L., Lövheim, H., Mancuso, R., Miklossy, J., Otth, C., Palamara, A. T., Perry, G., Preston, C., Pretorius, E., Strandberg, T., Tabet, N., Taylor-Robinson, S. D. \& Whittum-Hudson, J. A. (2016). Microbes and Alzheimer's Disease. J Alzheimers Dis 51, 979-984.

[332] Nussbaum, J. M., Seward, M. E. \& Bloom, G. S. (2013). Alzheimer disease: a tale of two prions. Prion 7, 14-9.

[333] Crapper McLachlan, D. R., Dalton, A. J., Kruck, T. P., Bell, M. Y., Smith, W. L., Kalow, W. \& Andrews, D. F. (1991). Intramuscular desferrioxamine in patients with Alzheimer's disease. Lancet 337, 1304-8.

[334] Smith, M. A., Harris, P. L. R., Sayre, L. M. \& Perry, G. (1997). Iron accumulation in Alzheimer disease is a source of redox-generated free radicals. Proc Natl Acad Sci 94, 9866-9868.

[335] Malecki, E. A. \& Connor, J. R. (2002). The case for iron chelation and/or antioxidant therapy in Alzheimer's disease. Drug Development Research 56, 526-530.

[336] Bush, A. I. (2003). The metallobiology of Alzheimer's disease. Trends Neurosci 26, 207-214.

[337] Bush, A. I. \& Tanzi, R. E. (2008). Therapeutics for Alzheimer's disease based on the metal hypothesis. Neurotherapeutics 5, 421-32.

[338] Kell, D. B. (2009). Iron behaving badly: inappropriate iron chelation as a major contributor to the aetiology of vascular and other progressive inflammatory and degenerative diseases. BMC Med Genom 2, 2

[339] Kell, D. B. (2010). Towards a unifying, systems biology understanding of large-scale cellular death and destruction caused by poorly liganded iron: Parkinson's, Huntington's,

Alzheimer's, prions, bactericides, chemical toxicology and others as examples. Arch Toxicol 577, 825-889. .

[340] Jomova, K. \& Valko, M. (2011). Importance of iron chelation in free radical-induced oxidative stress and human disease. Curr Pharm Des 17, 3460-3473.

[341] Smith, M. A., Zhu, X., Tabaton, M., Liu, G., McKeel, D. W., Jr., Cohen, M. L., Wang, X., Siedlak, S. L., Dwyer, B. E., Hayashi, T., Nakamura, M., Nunomura, A. \& Perry, G. (2010). Increased iron and free radical generation in preclinical Alzheimer disease and mild cognitive impairment. J Alzheimers Dis 19, 363-72.

[342] Guo, C., Wang, P., Zhong, M. L., Wang, T., Huang, X. S., Li, J. Y. \& Wang, Z. Y. (2013). Deferoxamine inhibits iron induced hippocampal tau phosphorylation in the Alzheimer transgenic mouse brain. Neurochem Int 62, 165-172.

[343] Pretorius, E., Bester, J. \& Kell, D. B. (2016). A bacterial component to Alzheimer-type dementia seen via a systems biology approach that links iron dysregulation and inflammagen shedding to disease $J$ Alzheimers Dis, in press.

[344] Valko, M., Jomova, K., Rhodes, C. J., Kuča, K. \& Musílek, K. (2016). Redox- and non-redoxmetal-induced formation of free radicals and their role in human disease. Arch Toxicol 90, 1-37.

[345] Nielsen, V. G. \& Jacobsen, W. K. (2016). Iron modulates the alpha chain of fibrinogen. Biometals 29, 235-8.

[346] Okada, A., Yoshikawa, Y., Watanabe, K. \& Orino, K. (2015). Analysis of the binding of bovine and human fibrinogen to ferritin: evidence that fibrinogen is a common ferritin-binding protein in mammals. Biometals 28, 679-85.

[347] van Oijen, M., Witteman, J. C., Hofman, A., Koudstaal, P. J. \& Breteler, M. M. (2005). Fibrinogen is associated with an increased risk of Alzheimer disease and vascular dementia. Stroke 36, 2637-41.

[348] Lee, J. W., Namkoong, H., Kim, H. K., Kim, S., Hwang, D. W., Na, H. R., Ha, S. A., Kim, J. R. \& Kim, J. W. (2007). Fibrinogen gamma-A chain precursor in CSF: a candidate biomarker for Alzheimer's disease. BMC Neurol 7, 14.

[349] Xu, G., Zhang, H., Zhang, S., Fan, X. \& Liu, X. (2008). Plasma fibrinogen is associated with cognitive decline and risk for dementia in patients with mild cognitive impairment. Int $\mathrm{J}$ Clin Pract 62, 1070-5.

[350] Marioni, R. E., Stewart, M. C., Murray, G. D., Deary, I. J., Fowkes, F. G., Lowe, G. D., Rumley, A. \& Price, J. F. (2009). Peripheral levels of fibrinogen, C-reactive protein, and 
bioRxiv preprint doi: https://doi.org/10.1101/054734; this version posted May 21, 2016. The copyright holder for this preprint (which was not certified by peer review) is the author/funder, who has granted bioRxiv a license to display the preprint in perpetuity. It is made available under aCC-BY 4.0 International license.

plasma viscosity predict future cognitive decline in individuals without dementia.

Psychosom Med 71, 901-6.

[351] Davalos, D. \& Akassoglou, K. (2012). Fibrinogen as a key regulator of inflammation in disease. Semin Immunopathol 34, 43-62.

[352] Noguchi, M., Sato, T., Nagai, K., Utagawa, I., Suzuki, I., Arito, M., lizuka, N., Suematsu, N., Okamoto, K., Kato, T., Yamaguchi, N. \& Kurokawa, M. S. (2014). Roles of serum fibrinogen alpha chain-derived peptides in Alzheimer's disease. Int J Geriatr Psychiatry 29, 808-18.

[353] Gupta, A., Watkins, A., Thomas, P., Majer, R., Habubi, N., Morris, G. \& Pansari, K. (2005). Coagulation and inflammatory markers in Alzheimer's and vascular dementia. Int J Clin Pract 59, 52-7.

[354] Ryu, J. K. \& McLarnon, J. G. (2009). A leaky blood-brain barrier, fibrinogen infiltration and microglial reactivity in inflamed Alzheimer's disease brain. J Cell Mol Med 13, 2911-25.

[355] Vinters, H. V. (1987). Cerebral amyloid angiopathy. A critical review. Stroke 18, 311-24.

[356] Kranenburg, O., Bouma, B., Kroon-Batenburg, L. M. J., Reijerkerk, A., Wu, Y. P., Voest, E. E. \& Gebbink, M. F. B. G. (2002). Tissue-type plasminogen activator is a multiligand crossbeta structure receptor. Curr Biol 12, 1833-9.

[357] Bussière, T., Bard, F., Barbour, R., Grajeda, H., Guido, T., Khan, K., Schenk, D., Games, D., Seubert, P. \& Buttini, M. (2004). Morphological characterization of Thioflavin-S-positive amyloid plaques in transgenic Alzheimer mice and effect of passive Abeta immunotherapy on their clearance. Am J Pathol 165, 987-95.

[358] Ly, P. T. T., Cai, F. \& Song, W. (2011). Detection of neuritic plaques in Alzheimer's disease mouse model. $J$ Vis Exp.

[359] Hultman, K., Strickland, S. \& Norris, E. H. (2013). The APOE $\varepsilon 4 / \varepsilon 4$ genotype potentiates vascular fibrin(ogen) deposition in amyloid-laden vessels in the brains of Alzheimer's disease patients. J Cereb Blood Flow Metab 33, 1251-8.

[360] Bhattacharjee, P. \& Bhattacharyya, D. (2015). An Enzyme from Aristolochia indica Destabilizes Fibrin-beta Amyloid Co-Aggregate: Implication in Cerebrovascular Diseases. PLoS One 10, e0141986.

[361] Austin, A. W., Wissmann, T. \& von Kanel, R. (2013). Stress and hemostasis: an update. Semin Thromb Hemost 39, 902-12.

[362] von Känel, R. (2015). Acute mental stress and hemostasis: When physiology becomes vascular harm. Thromb Res 135 Suppl 1, S52-5.

[363] Shah, N., Welsby, I. J., Fielder, M. A., Jacobsen, W. K. \& Nielsen, V. G. (2015). Sickle cell disease is associated with iron mediated hypercoagulability. J Thromb Thrombolysis 40, 182-5.

[364] Borgna-Pignatti, C. \& Gamberini, M. R. (2011). Complications of thalassemia major and their treatment. Expert Rev Hematol 4, 353-66.

[365] Reese, J. A., Bougie, D. W., Curtis, B. R., Terrell, D. R., Vesely, S. K., Aster, R. H. \& George, J. N. (2015). Drug-induced thrombotic microangiopathy: Experience of the Oklahoma Registry and the BloodCenter of Wisconsin. Am J Hematol 90, 406-10.

[366] Rosove, M. H. (2014). Thrombotic microangiopathies. Semin Arthritis Rheum 43, 797-805.

[367] O'Brien, S. H. (2014). Contraception-related venous thromboembolism in adolescents. Semin Thromb Hemost 40, 66-71.

[368] ESHRE CAPRI Workshop Group. (2013). Venous thromboembolism in women: a specific reproductive health risk. Hum Reprod Update 19, 471-82.

[369] Bateman, R. M., Ellis, C. G., Suematsu, M. \& Walley, K. R. (2012). S-nitrosoglutathione acts as a small molecule modulator of human fibrin clot architecture. PLoS One 7, e43660.

[370] Swanepoel, A. C., Lindeque, B. G., Swart, P. J., Abdool, Z. \& Pretorius, E. (2014). Estrogen causes ultrastructural changes of fibrin networks during the menstrual cycle: a qualitative investigation. Microsc Res Tech 77, 594-601.

[371] Lipinski, B. \& Pretorius, E. (2012). Hydroxyl radical-modified fibrinogen as a marker of thrombosis: the role of iron. Hematology 17, 241-7.

[372] Lipinski, B., Pretorius, E., Oberholzer, H. M. \& van der Spuy, W. J. (2012). Interaction of fibrin with red blood cells: the role of iron. Ultrastruct Pathol 36, 79-84.

[373] Bester, J., Buys, A. V., Lipinski, B., Kell, D. B. \& Pretorius, E. (2013). High ferritin levels have major effects on the morphology of erythrocytes in Alzheimer's disease. Front Aging Neurosci 5, 00088. 
bioRxiv preprint doi: https://doi.org/10.1101/054734; this version posted May 21, 2016. The copyright holder for this preprint (which was not certified by peer review) is the author/funder, who has granted bioRxiv a license to display the preprint in perpetuity. It is made available under aCC-BY 4.0 International license.

[374] Chu, A. J., Rauci, M., Nwobi, O. I., Mathews, S. T. \& Beydoun, S. (2003). Novel anticoagulant activity of polyamino acid offsets bacterial endotoxin-induced extrinsic hypercoagulation: downregulation of monocytic tissue factor-dependent FVII activation. $J$ Cardiovasc Pharmacol 42, 477-83.

[375] Chu, A. J., Wang, Z. G., Raicu, M., Beydoun, S. \& Ramos, N. (2001). Protamine inhibits tissue factor-initiated extrinsic coagulation. $\mathrm{Br} \mathrm{J}$ Haematol 115, 392-9.

[376] Slotta, J. E., Braun, O. Ö., Menger, M. D. \& Thorlacius, H. (2008). Central role of rho kinase in lipopolysaccharide-induced platelet capture on venous endothelium. J Investig Med 56, 720-5.

[377] Monroe, D. M. \& Key, N. S. (2007). The tissue factor-factor VIla complex: procoagulant activity, regulation, and multitasking. J Thromb Haemost 5, 1097-105.

[378] Koch, L., Hofer, S., Weigand, M. A., Frommhold, D. \& Poeschl, J. (2009). Lipopolysaccharide-induced activation of coagulation in neonatal cord and adult blood monitored by thrombelastography. Thromb Res 124, 463-7.

[379] Landsem, A., Fure, H., Christiansen, D., Nielsen, E. W., Østerud, B., Mollnes, T. E. \& Brekke, O. L. (2015). The key roles of complement and tissue factor in Escherichia coli-induced coagulation in human whole blood. Clin Exp Immunol 182, 81-89.

[380] Kaprelyants, A. S. \& Kell, D. B. (1992). Rapid assessment of bacterial viability and vitality using rhodamine 123 and flow cytometry. J. Appl. Bacteriol. 72, 410-422.

[381] Kaprelyants, A. S., Gottschal, J. C. \& Kell, D. B. (1993). Dormancy in non-sporulating bacteria. FEMS Microbiol. Rev. 10, 271-286.

[382] Kaprelyants, A. S. \& Kell, D. B. (1993). Dormancy in stationary-phase cultures of Micrococcus luteus: flow cytometric analysis of starvation and resuscitation. Appl. Env. Microbiol. 59, 3187-3196.

[383] Votyakova, T. V., Kaprelyants, A. S. \& Kell, D. B. (1994). Influence of viable cells on the resuscitation of dormant cells in Micrococcus luteus cultures held in extended stationary phase. The population effect. Appl. Env. Microbiol. 60, 3284-3291.

[384] Mukamolova, G. V., Kaprelyants, A. S., Young, D. I., Young, M. \& Kell, D. B. (1998). A bacterial cytokine. Proc. Natl. Acad. Sci. 95, 8916-8921.

[385] Mukamolova, G. V., Turapov, O. A., Young, D. I., Kaprelyants, A. S., Kell, D. B. \& Young, M. (2002). A family of autocrine growth factors in Mycobacterium tuberculosis. Mol Microbiol 46, 623-35.

[386] Mukamolova, G. V., Turapov, O. A., Kazarian, K., Telkov, M., Kaprelyants, A. S., Kell, D. B. \& Young, M. (2002). The rpf gene of Micrococcus luteus encodes an essential secreted growth factor. Mol Microbiol 46, 611-21.

[387] Mukamolova, G. V., Kaprelyants, A. S., Kell, D. B. \& Young, M. (2003). Adoption of the transiently non-culturable state - a bacterial survival strategy? Adv. Micr. Physiol. 47, 65129.

[388] Mukamolova, G. V., Murzin, A. G., Salina, E. G., Demina, G. R., Kell, D. B., Kaprelyants, A. S. \& Young, M. (2006). Muralytic activity of Micrococcus luteus Rpf and its relationship to physiological activity in promoting bacterial growth and resuscitation. Mol Microbiol 59, 8498.

[389] Kell, D. B., Potgieter, M. \& Pretorius, E. (2015). Individuality, phenotypic differentiation, dormancy and 'persistence' in culturable bacterial systems: commonalities shared by environmental, laboratory, and clinical microbiology. F1000Research 4, 179.

[390] Biancalana, M. \& Koide, S. (2010). Molecular mechanism of Thioflavin-T binding to amyloid fibrils. Biochim Biophys Acta 1804, 1405-12.

[391] Krebs, M. R. H., Bromley, E. H. \& Donald, A. M. (2005). The binding of thioflavin-T to amyloid fibrils: localisation and implications. J Struct Biol 149, 30-7.

[392] Wu, C., Biancalana, M., Koide, S. \& Shea, J. E. (2009). Binding modes of thioflavin-T to the single-layer beta-sheet of the peptide self-assembly mimics. J Mol Biol 394, 627-33.

[393] Freire, S., de Araujo, M. H., Al-Soufi, W. \& Novo, M. (2014). Photophysical study of Thioflavin T as fluorescence marker of amyloid fibrils. Dyes and Pigments 110, 97-105.

[394] Pinotsi, D., Michel, C. H., Buell, A. K., Laine, R. F., Mahou, P., Dobson, C. M., Kaminski, C. F. \& Kaminski Schierle, G. S. (2016). Nanoscopic insights into seeding mechanisms and toxicity of alpha-synuclein species in neurons. Proc Natl Acad Sci U S A. 
bioRxiv preprint doi: https://doi.org/10.1101/054734; this version posted May 21, 2016. The copyright holder for this preprint (which was not certified by peer review) is the author/funder, who has granted bioRxiv a license to display the preprint in perpetuity. It is made available under aCC-BY 4.0 International license.

[395] Galant, N. J., Bugyei-Twum, A., Rakhit, R., Walsh, P., Sharpe, S., Arslan, P. E., Westermark, P., Higaki, J. N., Torres, R., Tapia, J. \& Chakrabartty, A. (2016). Substoichiometric inhibition of transthyretin misfolding by immune-targeting sparsely populated misfolding intermediates: a potential diagnostic and therapeutic for TTR amyloidoses. Sci Rep 6, 25080.

[396] Lin, I. H., Miller, D. S., Bertics, P. J., Murphy, C. J., de Pablo, J. J. \& Abbott, N. L. (2011). Endotoxin-induced structural transformations in liquid crystalline droplets. Science 332, 1297-300.

[397] Miller, D. S. \& Abbott, N. L. (2013). Influence of droplet size, pH and ionic strength on endotoxin-triggered ordering transitions in liquid crystalline droplets. Soft Matter 9, 374-382.

[398] Carter, M. C. D., Miller, D. S., Jennings, J., Wang, X. G., Mahanthappa, M. K., Abbott, N. L. \& Lynn, D. M. (2015). Synthetic Mimics of Bacterial Lipid A Trigger Optical Transitions in Liquid Crystal Microdroplets at Ultra low Picogram-per-Milliliter Concentrations. Langmuir 31, $12850-12855$.

[399] Lowe, A. M. \& Abbott, N. L. (2012). Liquid Crystalline Materials for Biological Applications. Chem Mater 24, 746-758.

[400] Sadati, M., Apik, A. I., Armas-Perez, J. C., Martinez-Gonzalez, J., Hernandez-Ortiz, J. P., Abbott, N. L. \& de Pablo, J. J. (2015). Liquid Crystal Enabled Early Stage Detection of Beta Amyloid Formation on Lipid Monolayers. Adv Funct Mater 25, 6050-6060.

[401] Das, D., Sidiq, S. \& Pal, S. K. (2015). A Simple Quantitative Method to Study ProteinLipopolysaccharide Interactions by Using Liquid Crystals. ChemPhysChem 16, 753-760.

[402] Tan, L. N., Wiepz, G. J., Miller, D. S., Shusta, E. V. \& Abbott, N. L. (2014). Liquid crystal droplet-based amplification of microvesicles that are shed by mammalian cells. Analyst 139, 2386-2396.

[403] Hann, M. M. (2011). Molecular obesity, potency and other addictions in drug discovery. MedChemComm 2, 349-355.

[404] Hobbs, J. R. \& Morgan, A. D. (1963). Fluorescence Microscopy with Thioflavine-T in the Diagnosis of Amyloid. J Pathol Bacteriol 86, 437-42.

[405] Hill, J. M. \& Lukiw, W. J. (2015). Microbial-generated amyloids and Alzheimer's disease (AD). Front Aging Neurosci 7, 9.

[406] Ebert, E. C. \& Nagar, M. (2008). Gastrointestinal manifestations of amyloidosis. Am J Gastroenterol 103, 776-87.

[407] Domingue, G. J. \& Woody, H. B. (1997). Bacterial persistence and expression of disease. Clin Microbiol Rev 10, 320-344.

[408] Mattman, L. (2001). Cell wall deficient forms: stealth pathogens, 3rd Ed. CRC Press, Boca Raton.

[409] Woolard, M. D. \& Frelinger, J. A. (2008). Outsmarting the host: bacteria modulating the immune response. Immunol Res 41, 188-202.

[410] Nicolson, G. L. \& Haier, J. (2009). Role of chronic bacterial and viral infections in neurodegenerative, neurobehavioural, psychiatric, autoimmune and fatiguing illnesses: part 1. Br J Med Pract 2, 20-28.

[411] Proal, A. D., Albert, P. J. \& Marshall, T. (2009). Autoimmune disease in the era of the metagenome. Autoimmun Rev 8, 677-81.

[412] Domingue, G. J. (2010). Demystifying pleomorphic forms in persistence and expression of disease: Are they bacteria, and is peptidoglycan the solution? Discov Med 10, 234-46.

[413] Nicolson, G. L. \& Haier, J. (2010). Role of chronic bacterial and viral infections in neurodegenerative, neurobehavioural, psychiatric, autoimmune and fatiguing illnesses: part 2. Br J Med Pract 3, 301-310.

[414] Proal, A. D., Albert, P. J., Blaney, G. P., Lindseth, I. A., Benediktsson, C. \& Marshall, T. G. (2011). Immunostimulation in the era of the metagenome. Cell Mol Immunol 8, 213-25.

[415] Proal, A. D., Albert, P. J. \& Marshall, T. G. (2013). The human microbiome and autoimmunity. Curr Opin Rheumatol 25, 234-40.

[416] Proal, A. D., Albert, P. J. \& Marshall, T. G. (2014). Inflammatory disease and the human microbiome. Discov Med 17, 257-65.

[417] Mangin, M., Sinha, R. \& Fincher, K. (2014). Inflammation and vitamin D: the infection connection. Inflamm Res 63, 803-19.

[418] Billings, F. (1915). Focal infection. Appleton, New York. 
bioRxiv preprint doi: https://doi.org/10.1101/054734; this version posted May 21, 2016. The copyright holder for this preprint (which was not certified by peer review) is the author/funder, who has granted bioRxiv a license to display the preprint in perpetuity. It is made available under aCC-BY 4.0 International license.

[419] Price, W. A. (1923). Dental infections oral and systemic, being a contribution to the pathology of dental infections, focal infections and the degenerative diseases, Parts I and II. Penton Press, Cleveland.

[420] Little, C. S., Hammond, C. J., MacIntyre, A., Balin, B. J. \& Appelt, D. M. (2004). Chlamydia pneumoniae induces Alzheimer-like amyloid plaques in brains of BALB/c mice. Neurobiol Aging 25, 419-29.

[421] Wozniak, M. A., Itzhaki, R. F., Shipley, S. J. \& Dobson, C. B. (2007). Herpes simplex virus infection causes cellular beta-amyloid accumulation and secretase upregulation. Neurosci Lett 429, 95-100.

[422] Miklossy, J., Kis, A., Radenovic, A., Miller, L., Forro, L., Martins, R., Reiss, K., Darbinian, N., Darekar, P., Mihaly, L. \& Khalili, K. (2006). Beta-amyloid deposition and Alzheimer's type changes induced by Borrelia spirochetes. Neurobiol Aging 27, 228-36.

[423] Miklossy, J. (2008). Chronic inflammation and amyloidogenesis in Alzheimer's disease -- role of Spirochetes. J Alzheimers Dis 13, 381-91.

[424] Miklossy, J. (2011). Alzheimer's disease - a neurospirochetosis. Analysis of the evidence following Koch's and Hill's criteria. J Neuroinflammation 8, 90.

[425] Blanco, L. P., Evans, M. L., Smith, D. R., Badtke, M. P. \& Chapman, M. R. (2012). Diversity, biogenesis and function of microbial amyloids. Trends Microbiol 20, 66-73.

[426] Zhou, Y., Blanco, L. P., Smith, D. R. \& Chapman, M. R. (2012). Bacterial amyloids. Methods Mol Biol 849, 303-20.

[427] Taylor, J. D. \& Matthews, S. J. (2015). New insight into the molecular control of bacterial functional amyloids. Front Cell Infect Microbiol 5, 33.

[428] Van Gerven, N., Klein, R. D., Hultgren, S. J. \& Remaut, H. (2015). Bacterial amyloid formation: structural insights into curli biogensis. Trends Microbiol 23, 693-706.

[429] Benditt, E. P., Eriksen, N., Hermodson, M. A. \& Ericsson, L. H. (1971). The major proteins of human and monkey amyloid substance: Common properties including unusual $\mathrm{N}$-terminal amino acid sequences. FEBS Lett 19, 169-173.

[430] Sipe, J. (1999). Revised nomenclature for serum amyloid A (SAA). Nomenclature Committee of the International Society of Amyloidosis. Part 2. Amyloid 6, 67-70.

[431] Nedelkov, D., Kiernan, U. A., Niederkofler, E. E., Tubbs, K. A. \& Nelson, R. W. (2005). Investigating diversity in human plasma proteins. Proc Natl Acad Sci U S A 102, 10852-7.

[432] Malle, E. \& De Beer, F. C. (1996). Human serum amyloid A (SAA) protein: a prominent acute-phase reactant for clinical practice. Eur J Clin Invest 26, 427-35.

[433] Sipe, J. D. (2000). Serum amyloid A: from fibril to function. Current status. Amyloid 7, 10-2.

[434] Röcken, C. \& Shakespeare, A. (2002). Pathology, diagnosis and pathogenesis of AA amyloidosis. Virchows Arch 440, 111-22.

[435] Derebe, M. G., Zlatkov, C. M., Gattu, S., Ruhn, K. A., Vaishnava, S., Diehl, G. E., MacMillan, J. B., Williams, N. S. \& Hooper, L. V. (2014). Serum amyloid A is a retinol binding protein that transports retinol during bacterial infection. Elife 3, e03206.

[436] Yamada, T. (1999). Serum amyloid A (SAA): a concise review of biology, assay methods and clinical usefulness. Clin Chem Lab Med 37, 381-8.

[437] Pizzini, C., Mussap, M., Plebani, M. \& Fanos, V. (2000). C-reactive protein and serum amyloid A protein in neonatal infections. Scand J Infect Dis 32, 229-35.

[438] Urieli-Shoval, S., Linke, R. P. \& Matzner, Y. (2000). Expression and function of serum amyloid A, a major acute-phase protein, in normal and disease states. Curr Opin Hematol 7, 64-9.

[439] Falsey, A. R., Walsh, E. E., Francis, C. W., Looney, R. J., Kolassa, J. E., Hall, W. J. \& Abraham, G. N. (2001). Response of C-reactive protein and serum amyloid $A$ to influenza $A$ infection in older adults. J Infect Dis 183, 995-9.

[440] Obici, L., Perfetti, V., Palladini, G., Moratti, R. \& Merlini, G. (2005). Clinical aspects of systemic amyloid diseases. Biochim Biophys Acta 1753, 11-22.

[441] Arnon, S., Litmanovitz, I., Regev, R. H., Bauer, S., Shainkin-Kestenbaum, R. \& Dolfin, T. (2007). Serum amyloid A: an early and accurate marker of neonatal early-onset sepsis. $J$ Perinatol 27, 297-302.

[442] Bozinovski, S., Hutchinson, A., Thompson, M., Macgregor, L., Black, J., Giannakis, E., Karlsson, A. S., Silvestrini, R., Smallwood, D., Vlahos, R., Irving, L. B. \& Anderson, G. P. 
bioRxiv preprint doi: https://doi.org/10.1101/054734; this version posted May 21, 2016. The copyright holder for this preprint (which was not certified by peer review) is the author/funder, who has granted bioRxiv a license to display the preprint in perpetuity. It is made available under aCC-BY 4.0 International license.

(2008). Serum amyloid a is a biomarker of acute exacerbations of chronic obstructive pulmonary disease. Am J Respir Crit Care Med 177, 269-78.

[443] Cicarelli, D. D., Vieira, J. E. \& Bensenor, F. E. (2008). Comparison of C-reactive protein and serum amyloid a protein in septic shock patients. Mediators Inflamm 2008, 631414.

[444] Lannergård, A., Larsson, A., Friman, G. \& Ewald, U. (2008). Human serum amyloid A (SAA) and high sensitive C-reactive protein (hSCRP) in preterm newborn infants with nosocomial infections. Acta Paediatr 97, 1061-5.

[445] Çetinkaya, M., Özkan, H., Köksal, N., Çelebi, S. \& Hacımustafaoğlu, M. (2009). Comparison of serum amyloid A concentrations with those of C-reactive protein and procalcitonin in diagnosis and follow-up of neonatal sepsis in premature infants. J Perinatol 29, 225-31.

[446] Lannergård, A., Viberg, A., Cars, O., Karlsson, M. O., Sandström, M. \& Larsson, A. (2009). The time course of body temperature, serum amyloid A protein, C-reactive protein and interleukin- 6 in patients with bacterial infection during the initial 3 days of antibiotic therapy. Scand J Infect Dis 41, 663-71.

[447] Yuan, H., Huang, J., Lv, B., Yan, W., Hu, G., Wang, J. \& Shen, B. (2013). Diagnosis value of the serum amyloid A test in neonatal sepsis: a meta-analysis. Biomed Res Int 2013, 520294.

[448] Lundmark, K., Westermark, G. T., Nystrom, S., Murphy, C. L., Solomon, A. \& Westermark, P. (2002). Transmissibility of systemic amyloidosis by a prion-like mechanism. Proc Natl Acad Sci U S A 99, 6979-84.

[449] Tasaki, M., Ueda, M., Ochiai, S., Tanabe, Y., Murata, S., Misumi, Y., Su, Y., Sun, X., Shinriki, S., Jono, H., Shono, M., Obayashi, K. \& Ando, Y. (2010). Transmission of circulating cellfree AA amyloid oligomers in exosomes vectors via a prion-like mechanism. Biochem Biophys Res Commun 400, 559-62.

[450] Estrada, L. D., Yowtak, J. \& Soto, C. (2006). Protein misfolding disorders and rational design of antimisfolding agents. Methods Mol Biol 340, 277-93.

[451] Hawkes, C. A., Ng, V. \& McLaurin, J. (2009). Small Molecule Inhibitors of A beta-Aggregation and Neurotoxicity. Drug Development Research 70, 111-124.

[452] Cheng, P. N., Liu, C., Zhao, M., Eisenberg, D. \& Nowick, J. S. (2012). Amyloid beta-sheet mimics that antagonize protein aggregation and reduce amyloid toxicity. Nat Chem 4, 92733.

[453] López, L. C., Dos-Reis, S., Espargaró, A., Carrodeguas, J. A., Maddelein, M. L., Ventura, S. \& Sancho, J. (2012). Discovery of novel inhibitors of amyloid beta-peptide 1-42 aggregation. J Med Chem 55, 9521-30.

[454] Bieschke, J. (2013). Natural Compounds May Open New Routes to Treatment of Amyloid Diseases. Neurotherapeutics 10, 429-439.

[455] Cheng, B., Gong, H., Xiao, H., Petersen, R. B., Zheng, L. \& Huang, K. (2013). Inhibiting toxic aggregation of amyloidogenic proteins: a therapeutic strategy for protein misfolding diseases. Biochim Biophys Acta 1830, 4860-71.

[456] Stamford, A. \& Strickland, C. (2013). Inhibitors of BACE for treating Alzheimer's disease: a fragment-based drug discovery story. Cur Opin Chem Biol 17, 320-8.

[457] Flemming, A. (2014). Alzheimer's disease: Abeta-fibrinogen interaction inhibitor improves cognition in AD. Nat Rev Drug Discov 13, 494.

[458] Murakami, K. (2014). Conformation-specific antibodies to target amyloid beta oligomers and their application to immunotherapy for Alzheimer's disease. Biosci Biotechnol Biochem 78, 1293-305.

[459] Brumshtein, B., Esswein, S. R., Salwinski, L., Phillips, M. L., Ly, A. T., Cascio, D., Sawaya, M. R. \& Eisenberg, D. S. (2015). Inhibition by small-molecule ligands of formation of amyloid fibrils of an immunoglobulin light chain variable domain. Elife 4, e10935.

[460] Hanaki, M., Murakami, K., Akagi, K. \& Irie, K. (2016). Structural insights into mechanisms for inhibiting amyloid beta42 aggregation by non-catechol-type flavonoids. Bioorg Med Chem 24, 304-13.

[461] Cegelski, L., Pinkner, J. S., Hammer, N. D., Cusumano, C. K., Hung, C. S., Chorell, E., Åberg, V., Walker, J. N., Seed, P. C., Almqvist, F., Chapman, M. R. \& Hultgren, S. J. (2009). Small-molecule inhibitors target Escherichia coli amyloid biogenesis and biofilm formation. Nat Chem Biol 5, 913-9. 
bioRxiv preprint doi: https://doi.org/10.1101/054734; this version posted May 21, 2016. The copyright holder for this preprint (which was not certified by peer review) is the author/funder, who has granted bioRxiv a license to display the preprint in perpetuity. It is made available under aCC-BY 4.0 International license.

[462] Klein, R. D. \& Hultgren, S. J. (2015). Chaos controlled: discovery of a powerful amyloid inhibitor. Mol Cell 57, 391-3.

[463] Evans, M. L., Chorell, E., Taylor, J. D., Aden, J., Gotheson, A., Li, F., Koch, M., Sefer, L., Matthews, S. J., Wittung-Stafshede, P., Almqvist, F. \& Chapman, M. R. (2015). The bacterial curli system possesses a potent and selective inhibitor of amyloid formation. $\mathrm{Mol}$ Cell 57, 445-55.

[464] Cheng, S. B., Nakashima, A. \& Sharma, S. (2016). Understanding Pre-Eclampsia Using Alzheimer's Etiology: An Intriguing Viewpoint. Am J Reprod Immunol 75, 372-81.

[465] Ankarcrona, M., Winblad, B., Monteiro, C., Fearns, C., Powers, E. T., Johansson, J., Westermark, G. T., Presto, J., Ericzon, B. G. \& Kelly, J. W. (2016). Current and future treatment of amyloid diseases. J Intern Med.

[466] Ratner, J., Rosenberg, G., Kral, V. A. \& Engelsmann, F. (1972). Anticoagulant therapy for senile dementia. J Am Geriatr Soc 20, 556-9.

[467] Walsh, A. C., Walsh, B. H. \& Melaney, C. (1978). Senile-presenile dementia: follow-up data on an effective psychotherapy-anticoagulant regimen. J Am Geriatr Soc 26, 467-70.

[468] Walsh, A. C. (1996). Anticoagulant therapy for Alzheimer's disease. J Neuropsychiatry Clin Neurosci 8, 361-2.

[469] Barber, M., Tait, R. C., Scott, J., Rumley, A., Lowe, G. D. \& Stott, D. J. (2004). Dementia in subjects with atrial fibrillation: hemostatic function and the role of anticoagulation. $J$ Thromb Haemost 2, 1873-8.

[470] Murthy, S. B., Jawaid, A., Qureshi, S. U., Schulz, P. E. \& Schulz, P. E. (2009). The apolipoprotein 2 allele in Alzheimer's disease: suggestions for a judicious use of antiplatelet and anticoagulant medications. J Am Geriatr Soc 57, 1124-5.

[471] Letcher, R. L., Chien, S., Pickering, T. G., Sealey, J. E. \& Laragh, J. H. (1981). Direct relationship between blood pressure and blood viscosity in normal and hypertensive subjects. Role of fibrinogen and concentration. Am J Med 70, 1195-1202.

[472] Haenni, A. \& Lithell, H. (1996). Urapidil treatment decreases plasma fibrinogen concentration in essential hypertension. Metabolism 45, 1221-9.

[473] Shankar, A., Wang, J. J., Rochtchina, E. \& Mitchell, P. (2006). Positive association between plasma fibrinogen level and incident hypertension among men: population-based cohort study. Hypertension 48, 1043-9.

[474] Bembde, A. S. (2012). A study of plasma fibrinogen level in type-2 diabetes mellitus and its relation to glycemic control. Indian J Hematol Blood Transfus 28, 105-8.

[475] Sawyer, E. B. \& Gras, S. L. (2013). Self-assembling nanomaterials: monitoring the formation of amyloid fibrils, with a focus on small-angle X-ray scattering. Methods Mol Biol 996, 77101.

[476] Colvin, M. T., Silvers, R., Frohm, B., Su, Y., Linse, S. \& Griffin, R. G. (2015). High resolution structural characterization of Abeta42 amyloid fibrils by magic angle spinning NMR. J Am Chem Soc 137, 7509-18.

[477] Su, Y., Andreas, L. \& Griffin, R. G. (2015). Magic angle spinning NMR of proteins: highfrequency dynamic nuclear polarization and (1)H detection. Annu Rev Biochem 84, 465-97.

[478] Hopkins, A. L. (2008). Network pharmacology: the next paradigm in drug discovery. Nat Chem Biol 4, 682-690.

[479] Berger, S. I. \& lyengar, R. (2009). Network analyses in systems pharmacology. Bioinformatics 25, 2466-72.

[480] van der Graaf, P. H. \& Benson, N. (2011). Systems pharmacology: bridging systems biology and pharmacokinetics-pharmacodynamics (PKPD) in drug discovery and development. Pharm Res 28, 1460-4.

[481] Cucurull-Sanchez, L., Spink, K. G. \& Moschos, S. A. (2012). Relevance of systems pharmacology in drug discovery. Drug Discov Today 17, 665-670.

[482] Kell, D. B. \& Goodacre, R. (2014). Metabolomics and systems pharmacology: why and how to model the human metabolic network for drug discovery. Drug Disc Today 19, 171-182.

[483] Achenbach, J., Tiikkainen, P., Franke, L. \& Proschak, E. (2011). Computational tools for polypharmacology and repurposing. Future Med Chem 3, 961-8.

[484] Anighoro, A., Bajorath, J. \& Rastelli, G. (2014). Polypharmacology: Challenges and Opportunities in Drug Discovery. J Med Chem 57, 7874-7887. 
bioRxiv preprint doi: https://doi.org/10.1101/054734; this version posted May 21, 2016. The copyright holder for this preprint (which was not certified by peer review) is the author/funder, who has granted bioRxiv a license to display the preprint in perpetuity. It is made available under aCC-BY 4.0 International license.

[485] Hu, Y. \& Bajorath, J. (2010). Polypharmacology directed compound data mining: identification of promiscuous chemotypes with different activity profiles and comparison to approved drugs. J Chem Inf Model 50, 2112-8.

[486] Weinreb, O., Amit, T., Mandel, S., Kupershmidt, L. \& Youdim, M. B. (2010). Neuroprotective multifunctional iron chelators: from redox-sensitive process to novel therapeutic opportunities. Antioxid Redox Signal 13, 919-49.

[487] Weinreb, O., Amit, T., Bar-Am, O. \& Youdim, M. B. H. (2011). A novel anti-Alzheimer's disease drug, ladostigil neuroprotective, multimodal brain-selective monoamine oxidase and cholinesterase inhibitor. Int Rev Neurobiol 100, 191-215.

[488] Weinreb, O., Amit, T., Bar-Am, O. \& Youdim, M. B. H. (2012). Ladostigil: a novel multimodal neuroprotective drug with cholinesterase and brain-selective monoamine oxidase inhibitory activities for Alzheimer's disease treatment. Curr Drug Targets 13, 483-94.

[489] Kell, D. B. (2013). Finding novel pharmaceuticals in the systems biology era using multiple effective drug targets, phenotypic screening, and knowledge of transporters: where drug discovery went wrong and how to fix it. FEBS $\mathrm{J} \mathbf{2 8 0}, 5957-5980$.

[490] Mestres, J. \& Gregori-Puigjané, E. (2009). Conciliating binding efficiency and polypharmacology. Trends Pharmacol Sci 30, 470-4.

[491] Peters, J. U. (2013). Polypharmacology - Foe or Friend? J Med Chem 56, 8955-8971.

[492] Reddy, A. S. \& Zhang, S. (2013). Polypharmacology: drug discovery for the future. Expert Rev Clin Pharmacol 6, 41-7.

[493] Xie, L., Xie, L., Kinnings, S. L. \& Bourne, P. E. (2012). Novel computational approaches to polypharmacology as a means to define responses to individual drugs. Annu Rev Pharmacol Toxicol 52, 361-79.

[494] Borisy, A. A., Elliott, P. J., Hurst, N. W., Lee, M. S., Lehar, J., Price, E. R., Serbedzija, G., Zimmermann, G. R., Foley, M. A., Stockwell, B. R. \& Keith, C. T. (2003). Systematic discovery of multicomponent therapeutics. Proc Natl Acad Sci U S A 100, 7977-82.

[495] Lehár, J., Zimmermann, G. R., Krueger, A. S., Molnar, R. A., Ledell, J. T., Heilbut, A. M., Short, G. F., 3rd, Giusti, L. C., Nolan, G. P., Magid, O. A., Lee, M. S., Borisy, A. A., Stockwell, B. R. \& Keith, C. T. (2007). Chemical combination effects predict connectivity in biological systems. Mol Syst Biol 3, 80.

[496] Lehár, J., Stockwell, B. R., Giaever, G. \& Nislow, C. (2008). Combination chemical genetics. Nat Chem Biol 4, 674-81.

[497] Zimmermann, G. R., Lehár, J. \& Keith, C. T. (2007). Multi-target therapeutics: when the whole is greater than the sum of the parts. Drug Disc Today 12, 34-42.

[498] Small, B. G., McColl, B. W., Allmendinger, R., Pahle, R., Lopez-Castejon, G., Rothwell, N. J., Knowles, J., Mendes, P., Brough, D. \& Kell, D. B. (2011). Efficient discovery of antiinflammatory small molecule combinations using evolutionary computing Nature Chem Biol 7, 902-908.

[499] Li, D., Jones, E. M., Sawaya, M. R., Furukawa, H., Luo, F., Ivanova, M., Sievers, S. A., Wang, W., Yaghi, O. M., Liu, C. \& Eisenberg, D. S. (2014). Structure-based design of functional amyloid materials. J Am Chem Soc 136, 18044-51.

[500] Currin, A., Swainston, N., Day, P. J. \& Kell, D. B. (2015). Synthetic biology for the directed evolution of protein biocatalysts: navigating sequence space intelligently. Chem Soc Rev 44, 1172-1239.

[501] Nakano, M. \& Kamino, K. (2015). Amyloid-like conformation and interaction for the selfassembly in barnacle underwater cement. Biochemistry 54, 826-35. 